\title{
Régis Messac at McGill University, 1924-1929: \\ Fact and Fiction
}

\section{by Robert H. Michel}

\begin{abstract}
Régis Messac (1893-1945), French author of science fiction, satire and social criticism taught French at Montreal's McGill University from 1924 to 1929. A provocative thinker whose works are now being republished, his years at McGill inspired harsh criticism of American society and a satirical novel Smith Conundrum about the trials of teaching at a thinly disguised McGill. His satire is college fiction in the tradition of his fellow professor Stephen Leacock but harsher. This article reconstructs Messac's career at McGill, links his journalism during that time with his novel and traces how closely he used real people and events at McGill as inspirations for his satire. The article mainly draws on McGill's archival records, calendars, and student publications as well as Messac's own publications. ${ }^{1}$
\end{abstract}

\section{RESUMÉ}

Régis Messac (1893-1945), auteur français d’oeuvres de science fiction, de satire et de critique sociale, enseigna le français à l'Université McGill à Montréal de 1924 à 1929. Un penseur provocant dont les oeuvres sont aujourd'hui en réédition, ses années à McGill l’ont mené à critiquer sévèrement la société américaine et ont inspiré son roman Smith Conundrum qui traite des difficultés de l'enseignement à une Université McGill qui n’y est que très légèrement déguisée. Son oeuvre satirique de fiction collégiale est dans la tradition de son collègue, le professeur Stephen Leacock, mais est de nature plus sévère. Cet article reconstruit la carrière de Messac à McGill, établit des liens entre son journalisme et son roman durant cette époque, et examine la manière dont des gens et des événements à McGill lui ont servi de source d'inspiration directe pour son oeuvre satirique. L'article utilise principalement des documents d'archives, des calendriers et des publications étudiantes à McGill ainsi que les oeuvres publiées par Massac lui-même. ${ }^{1}$

\section{ASSISTANT PROFESSOR RÉGIS MESSAC}

\section{Messac and the McGill French Department}

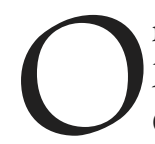
n 3 October 1924 a young French scholar, Régis Messac (1893-1945), answered the questions of Canadian immigration officials at Lacolle, Quebec. He was bound for Montreal, to McGill University, to teach French language and literature. Names? Régis Messac, age 30; accompanied by his wife Germaine, age 31, and sons Serge, age 3 years, Ralph, 25 days. They had arrived from France at New York on the S.S. De Grasse. The immigration questionnaires needed to be filled out three times: once typed by an official, once handwritten by Messac, and a third time, stamped "Guided," possibly indicating Messac needed prompting. On one form, he intends to stay three years, on another likely permanently. - Languages read? "English, French, Latin, Greek, German." - Religion? "Roman Catholic." - By whom passage ( $1^{\text {st }}$ class) paid? "French foreign office" [The French government assisted professors to teach abroad]. Messac had the equivalent of $\$ 175$ Canadian dollars. - Ever refused entry to or deported from Canada? "No." - Employer? "The McGill University." - Are you or any of your family mentally defective? "No." - Tubercular? "No." - Physically defective? "No." Messac may have suppressed sarcastic replies. Somehow the refilling of forms conveys his uneasiness with bureaucracy - prophetic of his reactions to McGill and later in the French educational system. The officials could not have guessed that they were admitting quietly subversive free thinkers to the conservative, largely Catholic province of Quebec (Fig. 1). In 1917 Messac had met Germaine Desvachez, who had left home at 17, traveled in Eastern Europe, and become governess in a Russian family. Régis and Germaine had been living en union libre when their first son Serge was born (28 Oct. 1921) and only married in 1922 after Régis received his agrégation dans l'ordre de la grammaire, as it would have been impossible for him to take up his first teaching post unless they conformed to the conventions. ${ }^{3}$

This article detects the realities behind Messac's satire about McGill University, Smith Conundrum and reconstructs his life at McGill from the "real-life" evidence of the University's archives and the "fictional" evidence of his autobiographical novel. What did Messac do in his unknown formative years at McGill from 1924 to 1929 ? What lay behind his novel? His main concern at McGill was the completion of his doctoral thesis for the Sorbonne, the first scholarly study of detective 
fiction: Le 'Detective Novel' (published 1929). Messac is best known for his science fiction dystopias Quinzinzinzili (1935), La Cité des asphyxiés (1937) and Valcrétin (posthumously, 1973). He has been rediscovered and republished. Many inédits - essays, novels, and letters are being published for the first time, opening a new window on the tormented decades between the World Wars. ${ }^{4}$ The Société des amis de Régis Messac publishes a journal, Quinzinzinzili: l'univers messacquien and a collection of studies, Régis Messac: un écrivain journaliste à reconnaitre appeared in 2011. Examined here are 1) Messac's teaching of French at McGill, 1924-1929, and 2) Messac's satirical autobiographical novel about his alter ego André Pluche's teaching French at Smith Conundrum University the same years. So many of the novel's characters and episodes resemble real life professors and events that one is tempted to read the novel as a memoir or roman à clef. But it is also a roman à thèse: Smith Conundrum University is mediocre. Though it is disguised as an American university, we recognize a negative, surreal version of McGill. The novel targeted students indifferent to learning; pompous, incompetent professors; snobbery; religion; Prohibition, Puritanism, militarism, and American-style quantitative

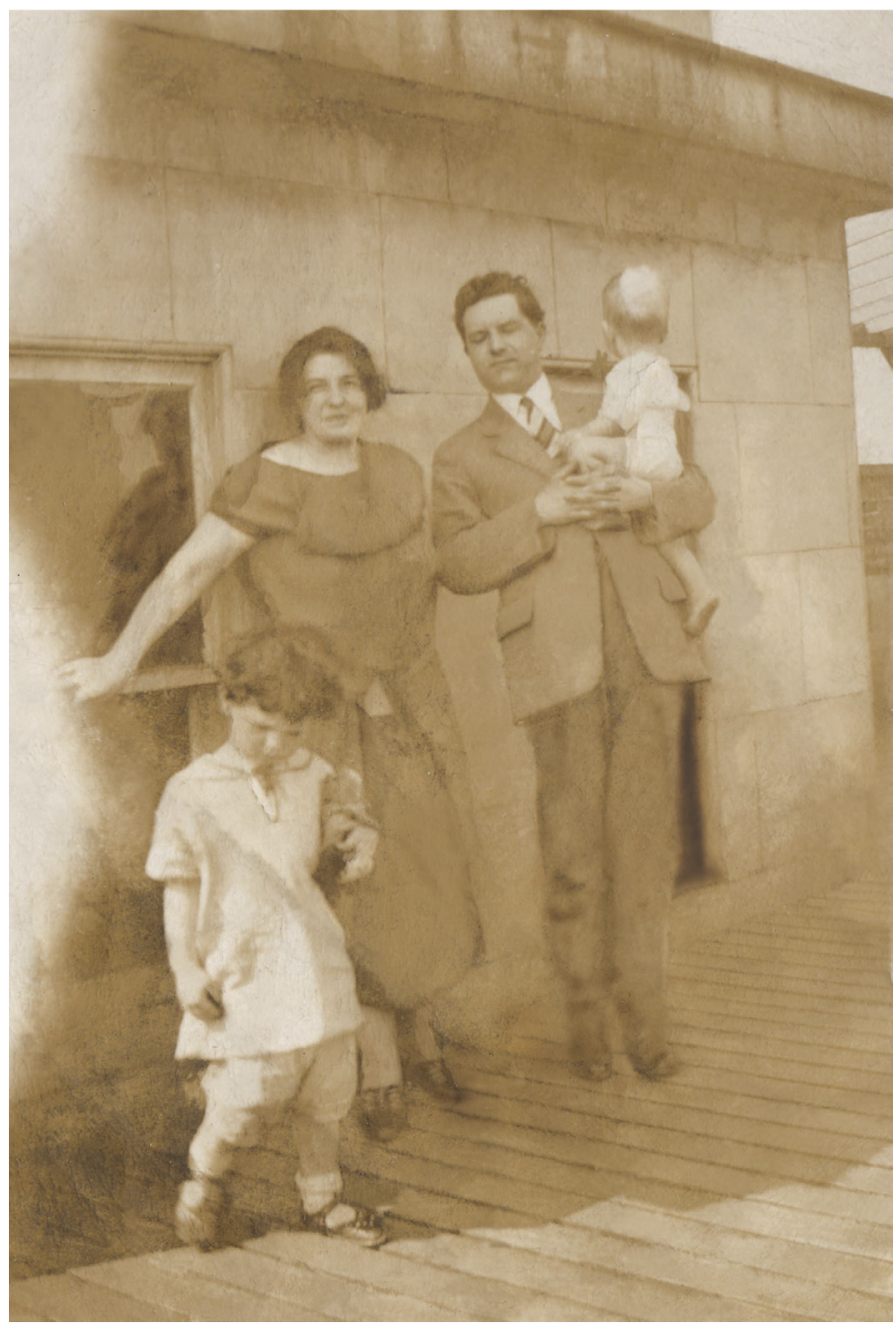

Figure 1. The Messac family in Montreal, ca. 1925, photographer unknown, courtesy O. Messac, Paris research. Very little has been written about Messac's five years at McGill yet they were pivotal to his development as a novelist and social critic. Likewise the connections between Smith Conundrum and Messac's career at McGill have never been fully explored. First, his career at McGill.

Born in France in 1893 to parents who were teachers, Messac was wounded early in the First World War and learned English working with British soldiers at Dunkirk docks. In 1922 he began to work on a doctoral thesis on the origins of the detective novel. It would be the first scholarly analysis of popular literature. His supervisor was Sorbonne professor Fernand Baldensperger, co-founder with Paul Hazard of the study of comparative literature. The detective novel had made its mark largely in English. To immerse himself in English while doing his research, Messac placed himself at the disposition of the French ministry of foreign affairs to teach abroad - first at University of Glasgow, where he was appointed for 1923-1924 to replace a staff member on sick leave, ${ }^{6}$ and then McGill University in Montreal from 1924 to 1929. One of McGill's attractions was its library. Messac used it heavily to research Poe and other authors for his thesis. When Messac arrived in October 1924, McGill had become Canada's best-known university, with a typical urban North American campus (Fig. 2). McGill was English-speaking, its attraction bolstered by the vibrant city of Montreal (population 750,000, 60\% French speaking). McGill had 3000 students, including 350 women. Unlike European universities, McGill was largely funded by private endowments and philanthropy from capitalists, including sugar refiner Peter Redpath, tobacco manufacturer Sir William Macdonald and railway magnate Lord Strathcona. Consequently, McGill was partly ruled and financially underwritten not by government but by its Board of Governors. Nearly all were businessmen; the Chancellor, Sir Edward Beatty, was the chairman of the Canadian Pacific Railway. [Messsac would find McGill, like Montreal, dominated by the commercial spirit, its staff, the lower ranks at least, little better off than the Governors' chauffeurs.] Students, however, enjoyed great freedom, access to English and French culture, drank alcohol (no Prohibition in Quebec), and attended mixed "co-ed" classes. We will see that Messac was struck by the wealth and racial and religious diversity of McGill. Some students came from Montreal's rich families, mainly of Scottish and English descent; most were middle class, drawn mainly from anglophone Montreal but also from the rest of Canada, the United States, and Britain. Students entered at age 17 or 18 , studied for 4 years or more in Arts, Science, Commerce, Engineering, Medicine, Law, Pharmacology, Nursing, etc. Tuition, board, lodging and other expenses came to around $\$ 600$ (bare minimum for Arts) to $\$ 1,000$ Canadian dollars per year. ${ }^{8}$

Messac might never have come to McGill if a violent dispute had not led to the creation of a separate, slightly expanded French department. In 1921 Swiss-born Professor Hermann Walter, ${ }^{9}$ Chairman of the Modern Languages Department, 
who taught German, accused Assistant Professor Joseph L. Morin, ${ }^{10}$ who taught French in the same department, of poisoning the well of his country house. This led to acquittals, suits and countersuits between Walter and Morin dragging on from 1921 to 1924 and later. The Principal, Sir Arthur Currie, and the Governors feared McGill's reputation would suffer because of the conflict. Currie suspended Walter and Morin, then reinstated Walter, then suspended him again. The archival record shows the fluctuation and backtracking of university governance. ${ }^{11}$ For a while, Currie seemed to favor Morin but the case was inconclusive. By 1922 Currie had decided the Department should be re-organized and by 1923 the 68 year-old Morin was forced to retire and Modern Languages was split into a Germanic Languages Department headed by Walter and a Romance Languages Department headed by French-born René du Roure. ${ }^{12}$ Due to a bias against the Quebec French accent, Morin was probably the last French Canadian on the fulltime French Department teaching staff until the 1960s. Du Roure and McGill's administrators preferred teachers born in France or at least in Europe. ${ }^{13}$

Morin's retirement made way for new appointments, first of André J. Roche in 1923 as Lecturer, then Messac by early July 1924 at the higher level of Assistant Professor. Messac had testimonials from his Agrégation examiners: Professor René Durand praised Messac's precision, clarity of expression and composition, while Professor Fèlix Gaiffe noted Messac had received the highest mark at his examination, that his teaching was excellent, and that any foreign university would find him an excellent professor. ${ }^{14}$ Messac's chairman at Glasgow, 1923-1924, Charles A. Martin, warmly recommended him, praising his teaching at upper levels: Messac had delivered

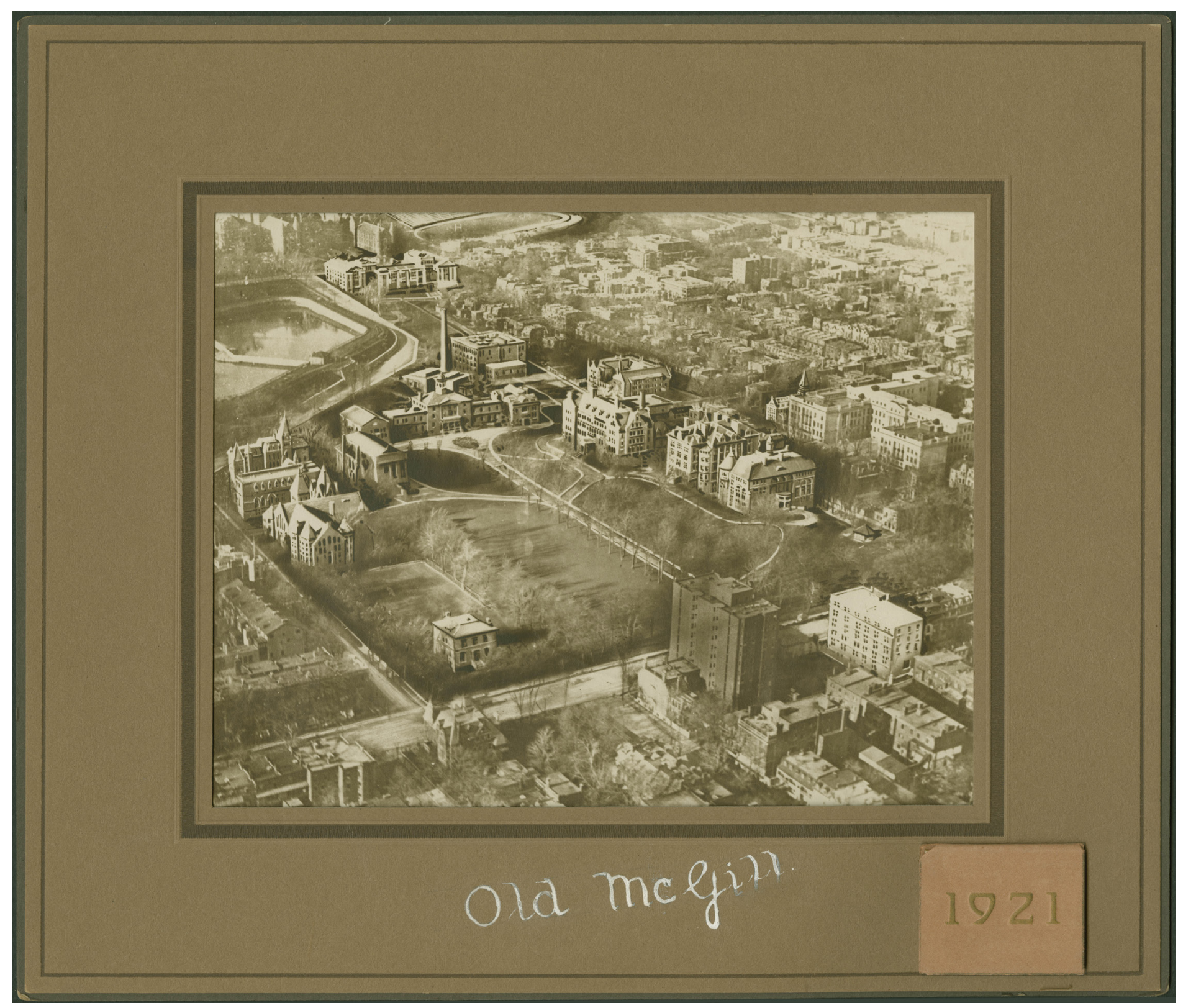


courses of lectures on the history of the French language and on French literature to students preparing for the M.A. Degree. He also taught 150 second year students in tutorial classes. "Monsieur Messac has a very keen sense of the value of the 'nuances' of expression in French, and is able to explain French Classical Texts, and also old French Texts, in a lucid, interesting, scholarly and profitable manner. I always found Monsieur Messac most conscientious, zealous, punctual and obliging, and I know that his work with the students has been very helpful to them indeed. He is a very kind \& devoted colleague." 15

The McGill student body was expanding and French courses were in high demand. McGill's small French Department prided itself on teaching entirely in French and offering a French environment in Montreal. It faced large classes (in the Arts Building, Fig. 3). Classes of 30 students were considered large and some had over 50, as McGill statistics and Messac's novel both testify. Messac with four or five others taught introductory and advanced language and literature courses. He was often paired with the department head du Roure, an indication of his importance. Courses and content varied by year; the following summarizes Messac's teaching. Messac and others, including du Roure, taught French Language First Year-three one hour lectures per week. The course included composition, French history texts, Dumas, Racine, Merimee, and Moliere's Le Bourgeois Gentilhomme. Similarly, Messac with others taught sections of Second Year language and literature courses; included were a variety of works such as Moliere's Les précieuses ridicules, Émile Augier, Le Gendre de M. Poirier, La Fontaine, Fables, as well as the recent romance about rural Quebec, Louis Hémon's Marie Chapdelaine. In 1926-1927 Messac taught fourth year students earlier $19^{\text {th }}$. century French literature, including Chateabriand and Balzac, and (presumably for translations) the recent best seller of du Roure's friend Stephen Leacock, My Discovery of England (1922). Other French courses also used My Discovery. With du Roure Messac taught Gil Blas, selections from Rousseau

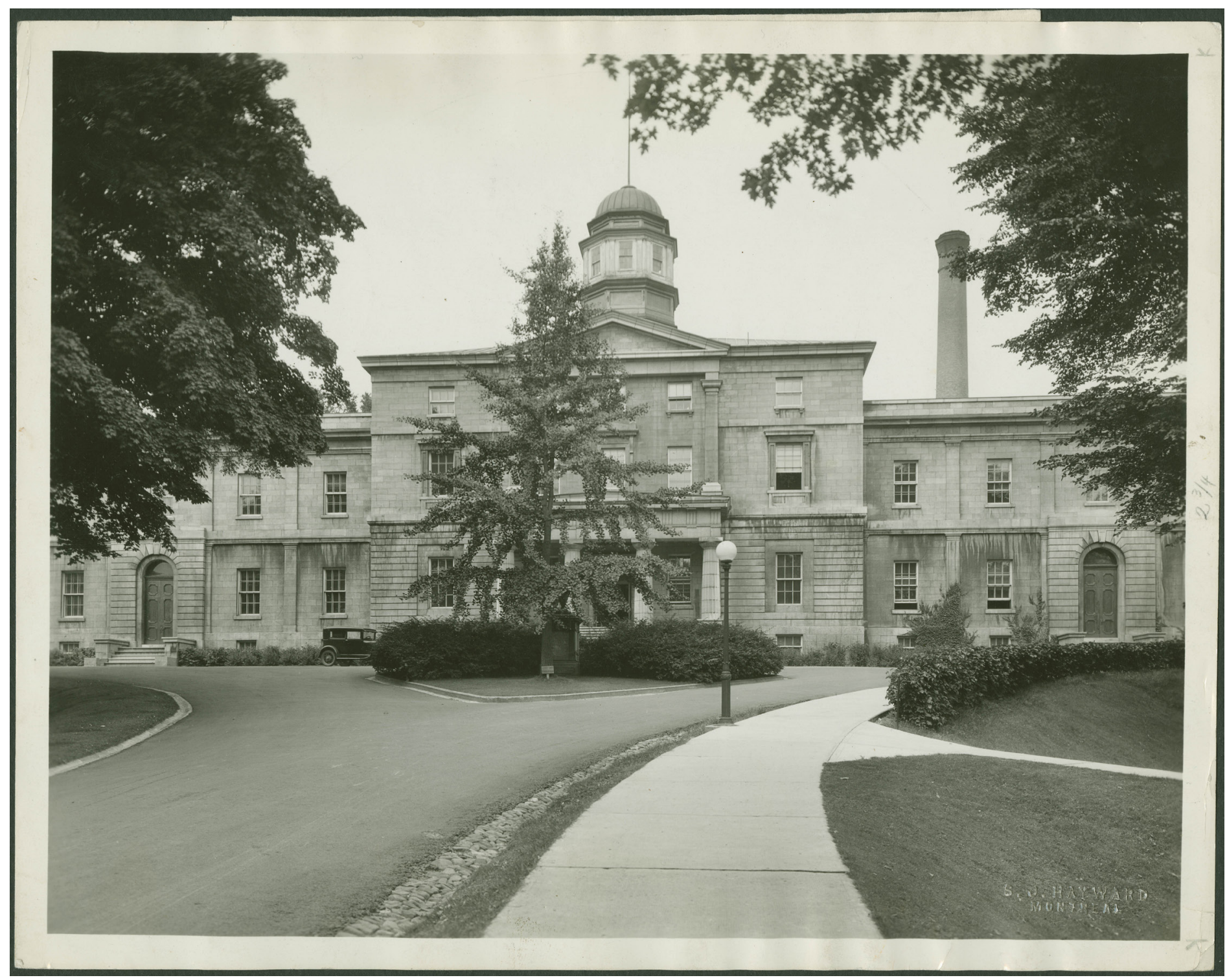

Figure 3. Arts Building, 1929, photographer S.J. Hayward, MUA PR026608 
and Voltaire, Beaumarchais, Hugo, Hernani; Balzac, and le père Goriot. Messac collaborated with du Roure (who loved staging theatre) in the course on $19^{\text {th }}$ century French theatre for honours and graduate students. Yet again paired with du Roure, he gave the honours course on the Evolution of the French Lyric. With Lucie Touren Furness, Messac taught later $19^{\text {th }}$ and $20^{\text {th }}$ century French literature, including Flaubert, Maupassant and Anatole France. In 1928-1929 with Lecturer Jeanne Durand-Joly, Messac taught French literature of the $17^{\text {th }}$ and $18^{\text {th }}$ centuries, including Racine's Phèdre. He would immortalize his attempt to teach Phèdre in his novel. As du Roure appreciated Messac's abilities, Messac's responsibilities and teaching levels increased. By 1926-1927 Messac had joined Touren Furness as an Associate of the Graduate Studies Faculty (du Roure was a full member) and in giving courses for graduate Master of Arts students. The French M.A. program included an English course in Comparative Literature, taught in alternate years by young English Department Assistant Professors Algy Noad and Harold Files, with whom Messac must have had interests in common. Noad was interested in utopias and his teaching and research notes briefly cite Messac on Poe; ${ }^{16}$ neither man appears to have inspired characters in Smith Conundrum. At the graduate level Messac taught Méthodologie (mandatory for the degree). He also taught an honours course on Balzac; this course and the History of Theatre given with du Roure were also offered as options to graduate students. ${ }^{17}$

Most French professors lectured 12 or 13 hours per week. Every year more students took French. In Fall 1926 there were five class sections with over fifty students and du Roure requested a temporary lecturer for the session, warning he would soon need a graduate student to give supplementary lectures to the "backward students" taking first year French. ${ }^{18}$ We will see the backward students in the novel-as well as the piles of examinations to mark. By Fall 1927 the situation was no better. Nothing was done. The conditions Messac would satirize were endemic to many universities: classes too large, not enough staff, and no help from the deans, who pleaded insufficient funds. McGill was strongest in medicine and the sciences. The higher administrators saw the French Department as worthy but mediocre with no stars such as Leacock. Messac might have become a star but left too soon. $\mathrm{Du}$ Roure was a good teacher but not a published scholar; he had dashing style but little clout as department head. A report by Dean of Arts Ira MacKay written just after Messac left McGill in 1929 sums up the state of the French Department and its methods:

The staff of this department is distinctly miscellaneous. Nevertheless it is doing good work. The standards in the French language are much higher than in any other of the Universities of the English-speaking Provinces.... French is the language of instruction in all classes. Not a word of English is spoken except to a small special group of students in the first year coming from wholly English-speaking communities. Half the students in the College [mainly Arts students] can read French, and 500 can listen to a lecture or play in French and understand it fully. ${ }^{19}$

\section{La civilisation américaine}

Messac's writing at McGill was prodigious. His greatest concern was his thesis; his novel's alter ego Pluche is similarly obsessed. At McGill, Messac (with Germaine's help) did most of the research and writing of the 698 page $\mathrm{Ph} . \mathrm{D}$. thesis Le 'Detective Novel' (published 1929, republished 2011); its foreword is dated 31 October 1928 at Montreal. ${ }^{20} \mathrm{He}$ also published an autobiographical anti-war novel Le Voyage de Néania in 1926. ${ }^{21}$ During his McGill years he published articles in scholarly journals on Bulwer-Lytton \& Dostoyevsky, Fenimore Cooper, Voyages modernes au centre de la terre, and Déterminisme et histoire littéraire. ${ }^{22}$ To cite an example of his close research on the origins of the detective novel (mainly in the $18^{\text {th }}$ and $19^{\text {th }}$ centuries), Messac corresponded in 1927 1928 with the librarians of West Point and of the University of Virginia about books by Voltaire and others which he thought Edgar Allan Poe might have borrowed to read while a student there. ${ }^{23}$ Messac's supplementary thesis was on French influences on Poe, and Poe of course was a major subject of Le 'Detective Novel.' Writing to the Poe scholar, Thomas Mabbott in 1928, Messac cited the complexities of hunting for Poe's French influences and indicated Baldensperger had thrust this supplementary topic on him after rejecting alternatives. ${ }^{24}$ Le 'Detective Novel' remains a classic authority on the origins of the genre; the crime novelist P.D. James cited it recently in her Talking About Detective Fiction (2009). ${ }^{25}$

The writings of Messac from his McGill period that are most akin to his novel are not his academic writings but his social criticism of America, in articles published from 1925 onward in Le Progrès civique, a leftist Paris journal. They recently have been examined by Astrid Llado. ${ }^{26}$ Pierre-Gilles Pélissier traces the seeds of Messac's science fiction novels of the 1930 s to his journalism. ${ }^{27}$ One may argue similarly that Smith Conundrum originated in Messac's analyses of America written while he was at McGill; indeed, he published the chapters of his novel of an "American" university alongside his American journalism in Le Progrès civique. Emphasized here are those articles which related to his views on university education or which show preoccupations similar to those in Smith Conundrum. He penned them from his perch in Montreal where he could read the American press and where attitudes reflected the American culture next door. ${ }^{28}$ After the First World War, French readers became fascinated by the swelling wealth, power and influence of the United States. Messac focused on America in his articles for the same reasons that he would make Smith Conundrum University 
American - he and his French readers were interested in the United States not Canada or Quebec.

A harsh, modern de Tocqueville, Messac decried America's materialism, conformity, primitivistic influence on Europe, mistreatment of Negroes, religious fundamentalism, Prohibition (his essay on Prohibition set off a controversy), tabloid sensationalism, fraudulent psychiatry, eugenics theories, and the failings of Christian Science (more controversy). His attacks were so fierce that French nationals living in America protested. ${ }^{29}$ Messac (and the journal's other writers, who included George Orwell) attacked war-mongering, religious and sexual puritanism, racism, nationalism, colonialism and capitalism. To readers 80 years later, Messac's opinions expressed in Le Progrès civique seem presciently modern and on the humane side of issues which still plague the world today. Astrid Llado argues that Messac did not intend to compare America unfavorably to France so much as against an ideal society toward which all who shared the journal's ideal of social improvement strove. ${ }^{30}$

In his first article for Le Progrès civique, in November 1925, Messac focused on American workers' desires to own cars and how they were duped by salesmen who got people to buy cars they could not afford on the instalment plan; he knew a janitor whose salary went to monthly payments for car, furniture, and electric washing machines. ${ }^{31}$ Weeks later, he ridiculed the flourishing (American) Ku Klux Klan and its ponderous hierarchy, ceremonies and its tarring and feathering of Blacks, anarchists and socialists. But fairly he concluded that France-the most individualist nation on earth-had also yielded to collective hysteria (probably referring to the Dreyfus Affair)..$^{32}$ In March 1926, from "wet" Quebec, Messac dissected America's Prohibition, pointing out a majority had banned alcohol; now a majority swilled it illegally. He suggested that Americans, maybe all AngloSaxons, found the thrill in drunkenness that Latins found in concupiscence. ${ }^{33}$ Responding to readers' criticism, he countered that alcohol gave the poor an escape; he recalled seeing the gaunt poor of Glasgow and understood why they drank whisky. Alcohol gave them a substitute for everything they lacked: joy, light, warmth, clean lodgings, etc. It would be criminal to take alcohol away without improving their social conditions. Hypocritical religion and the clergy were largely to blame for prohibition! ${ }^{34}$

In January 1926 Messac ridiculed American immigration rules with their "scientific" tests for admissibility and the barrage of personal questions which were pervaded by political, racial and eugenic fears. ${ }^{35}$ One must swear that one was not a Bolshevik, anarchist, nor a polygamist. [Leacock had made the same points in My Discovery of England (1922). ${ }^{36}$ ] Likewise one must not be syphilitic or tubercular. He also noted U.S. immigration authorities were tough on Jews. As well immigrants had to pass an intelligence test. Messac saw these tests as attempts to disqualify immigrant hordes and preserve the ideals of America's puritan pioneers and the positions of their descendants. However, the test's questions were so stupidly phrased that they hinted at the answers required. ${ }^{37}$ Here and later in Smith Conundrum, we see Messac's attitudes toward testing; he derided America's naïve belief in standardized intelligence tests such as Binet's and the obsession with "scientific" measurement and efficiency-now seducing admirers in France. Moreover, as he could read in the McGill Daily, American universities were introducing intelligence and psychological tests for admissions and other purposes. ${ }^{38}$

In April 1926 McGill held a special ceremony conferring honorary degrees on a French and a British dignitary. The episode demonstrates perfectly how Messac reacted to actual events and used them in both his journalism and his McGill novel; he rushed into print in Le Progrès civique a few weeks later with his strongest attack on American universities and used the degree ceremony for one of the most caustic chapters of Smith Conundrum (discussed later). In August 1926 Messac decried Jim Crowism and lynchings yet suggested America might prove a favorable place for the future of Blacks, prophetically, as Astrid Llado points out, with Barack Obama's winning the Presidency. ${ }^{39}$ Next Messac fired at fundamentalist religion, describing a church service he said he attended in New York on 1 August 1926. The congregation swayed, the preacher waved his arms and cried "Religion is a light!" Messac hears it as: "Religion is a lie." ${ }^{40}$ American material culture was as bad as its bogus religion: in January 1927 Messac wrote on American hygiene-he ranged from dirty hotel bathrooms to Americans' love of wearing huge round glasses and gold teeth. Apartments were overheated and undersized, furniture mass produced and ugly, and cuisine of the "quick-lunch-bar" horrible. ${ }^{41}$ His novel would rail against overheated offices and the mashed potatoes at the Faculty Club. Next he wrote on Herman Melville-perhaps an off-shoot of research for his thesis, which referred to Melville's Confidence Man. ${ }^{42}$

In April 1927 he reported on how Americans viewed Anatole France. ${ }^{43}$ The article resulted directly from his research and teaching; France appeared in both his thesis and his courses. In July 1927, as a pioneering student of popular literature, he praised American tabloids-not for their lurid stories about love and murder but for their short spicy language, catchy headlines, and frequent change of tone and typesets. ${ }^{44}$ In August 1927 he argued that single women had more freedom in America than Europe-no need to be part of a household. But he thought both single and married women wasted their time playing tennis, going to clubs and charitable societies. In passing, he noted Americans avoid unpleasant subjects by telling funny anecdotes. Humour is the accomplice of hypocrisy, he declared, possibly thinking of the affectionate college satires of Leacock or the clumsy jocular columns in the McGill Daily. Perhaps criticizing subjects like the lighter ones he heard debated by the Cercle Français at McGill, he ridiculed debating clubs which avoided troubling 
social issues in favour of such questions as "Should there be marriage bureaus in Universities?" and "Can a woman with cropped hair make a good housewife?" ${ }^{45}$ In one of his more provocative articles (December 1927), he attacked American Christian Science and its avoidance of medicine, evoking an angry rebuttal. ${ }^{46}$

Messac gravitated to the writings of Sinclair Lewis (author of Babbit, 1922) and Upton Sinclair who stridently voiced and probably helped shape Messac's own distrust of American middle class and business culture. Writing in 1926 Messac had defined Americans as Sinclair Lewis's archetype Babbit-conformists with their eyes on profit, who saw studying poetry, French and other subjects at university as a waste of time which would never earn a cent. ${ }^{47}$ Perhaps he was thinking of some of his students. Since he was writing for French readers, Messac may be forgiven perhaps for harping on the Babbit middle class stereotypes; they already were being fiercely attacked by American writers in the 1920s. Upton Sinclair, like Messac, promoted his social views in both fictional and nonfictional writing. In April 1928 Messac aired Upton Sinclair's arguments that literature and art usually served as propaganda for causes and that American writers were slaves to plutocracy. ${ }^{48}$ If Messac read Sinclair's Goose-step (1923), he must have approved of its fierce indictment of American universities for serving the moneyed establishment and for promoting sports to attract alumni donations. McGill and other universities in the mid-1920s debated whether sport was over-emphasized to help raise funds from alumni. In similar vein, the McGill student Cercle Français, in which Messac took part actively, had debated the effects of professionalization of sport in November 1926. In Le Progrès civique in August 1928 Messac, probably stirred by that ongoing debate, criticized America's obsession with professional sports, which instead of fostering public health focused on individuals and breaking records. He ridiculed sports idols with infantile brains-like Harry Swellhead, whom we will meet in Smith Conundrum. Declaring that Yale made $\$ 800,000$ each year on its football team, Messac charged in both this article and his McGill novel that the star athlete has the university at his feet. No need to take exams, he is passed in advance. How would a professor dare fail an athlete? He knows he will be broken if he tries. Everyone knows that the coach (perhaps thinking of McGill's admired football coach Frank Shaughnessy) is a more considerable figure and paid more than any professor. ${ }^{49}$ In July 1928 Messac wrote on revolutions: they are not just barricades and red flags but a redressing of justice, an excremental purging and redistribution of wealth for which even America may be ripe someday. ${ }^{50}$ His last article for Le Progrès civique to be written from McGill (December 1928) was about possible war between America and Japan for economic and military control of the Pacific. His discussion of economic, military and moral issues was informed, prophetic and distrustful of militarism among politicians and the blind public. ${ }^{51}$

\section{Quebec in Retrospect}

Messac wrote about the United States although he did not live there. What about Quebec, where he did live? Little evidence of the Messacs' daily lives survives except their rented homes. In Montreal, the Messacs lived first in a modest apartment building on downtown lower Rue St-Denis, next in attractive residential areas: a triplex on Blvd. St-Joseph, and lastly on Rue Molson opposite a park. ${ }^{52}$ We can safely assume Messac knew many McGill staff members, including those parodied in Smith Conundrum. He certainly knew his fellow instructor in the McGill French Summer School, French-born Marie Le Franc. Reviewing Le Franc's Au pays Canadien-français in 1932, he admitted she was a great lyrical poet and had lived in Canada longer than he but he could not recognize the Quebec she described. She ignored what Messac noticed most, the crooked politicians and the priests with their air of feudal lords. Perhaps her publishers wanted to please French Canadians; lightheartedly he concludes: Well, all travelers are liars.... ${ }^{53}$

In June 1935 his "Histoires Canadiens" in L'Idée Libre gave two very uncomplimentary vignettes of Quebec's Catholic clergy. He recalled the Laurier-Palace movie theatre fire of Sunday 9 January 1927 in Montreal East in which 78 children, French-Canadian Catholics, were suffocated trying to escape a fire. The Catholic clergy, he said, had called it the vengeance of God on Montreal's sins and it inspired a popular lament: that God had needed angels for paradise. Fortunate children, commented Messac, to proceed directly to heaven and expiate the sins of their elders! More personal, Messac related his wife Germaine's brush with the Catholic clergy. For two years, they had lived on Blvd. Saint-Joseph Est opposite église Saint-Pierre-Claver, named for a Jesuit missionary (1580-1654) - who was eaten by "les sauvages," Messac claimed gleefully but erroneously. The church had a small park where Germaine would take the children to play (Fig. 4). Inevitably, one day the vicar, Zacharie Picotte, approached her. [Messac does not mention that Picotte, born 1872, had recently published a book about Pierre Claver. ${ }^{54}$ ] -Are these little angels yours? he asked. Yes, she replied. Then they will soon be old enough for catechism. No, their father would never consent! -Would not consent! But do you realize the little cherubs will roast in hell? He described hell's torments imaginatively. Germaine finally cut him short: Useless, Monsieur le Curé. In fact, I should tell you we are married civilly. An even greater shock to the priest. -Madame, savez-vous que vous êtes en état de concubinage! $\mathrm{He}$ offered to marry them in church. My husband would never consent, replied Germaine. Upon which (while Régis obliviously read his English authors across the street in their apartment), the priest offered Germaine what Régis, knowing the audacity of Quebec priests, at first thought must be a fraud: the priest could marry her in the church, without Régis's knowing, through the ceremony of sanatio in radice, in which she alone need give her consent. Later Messac checked 


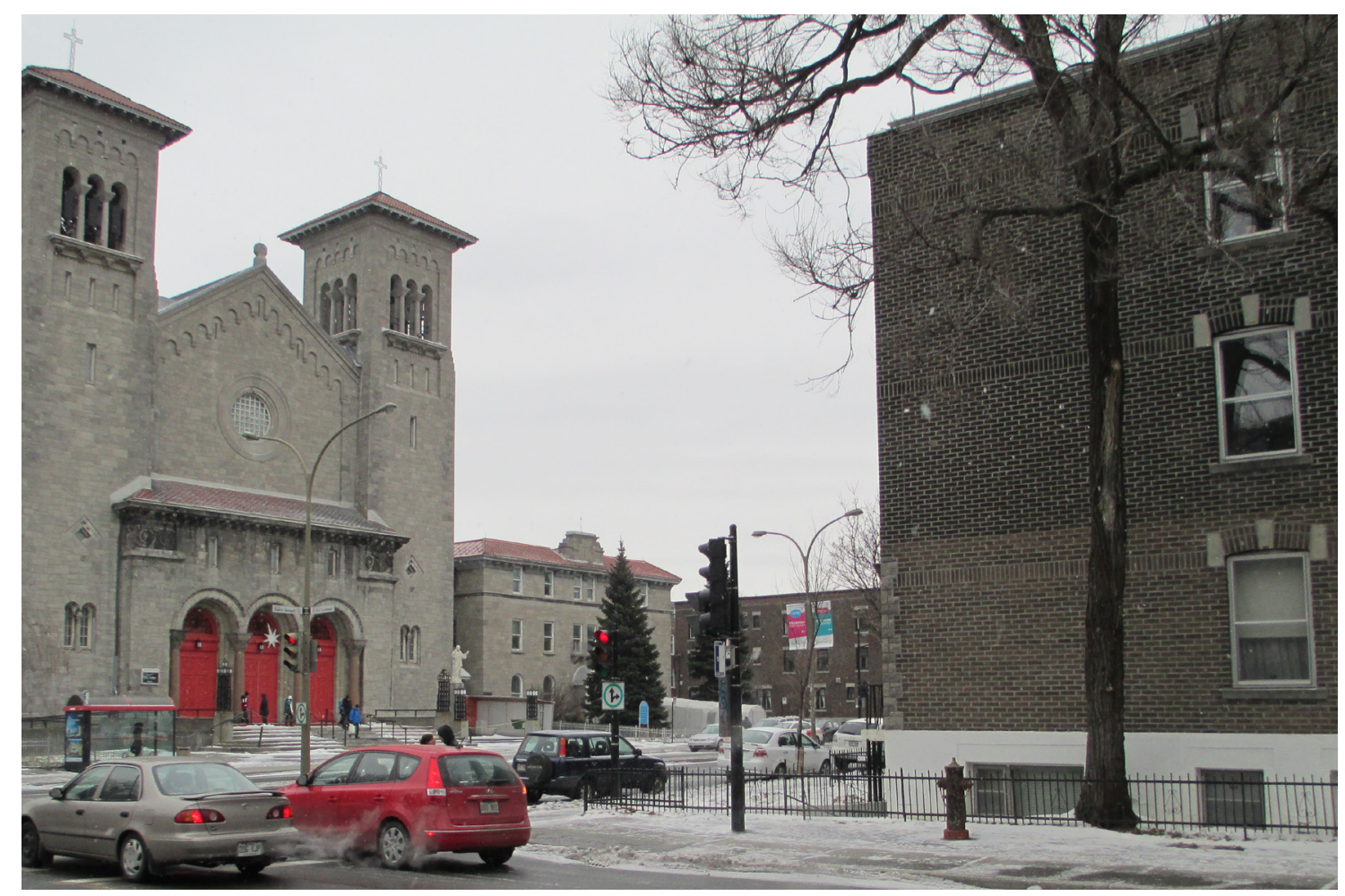

Figure 4. Messac apartment (R), 2045 St-Joseph E., Montreal, opposite Église St-Pierre-Claver, photographer Robert Michel, 2012

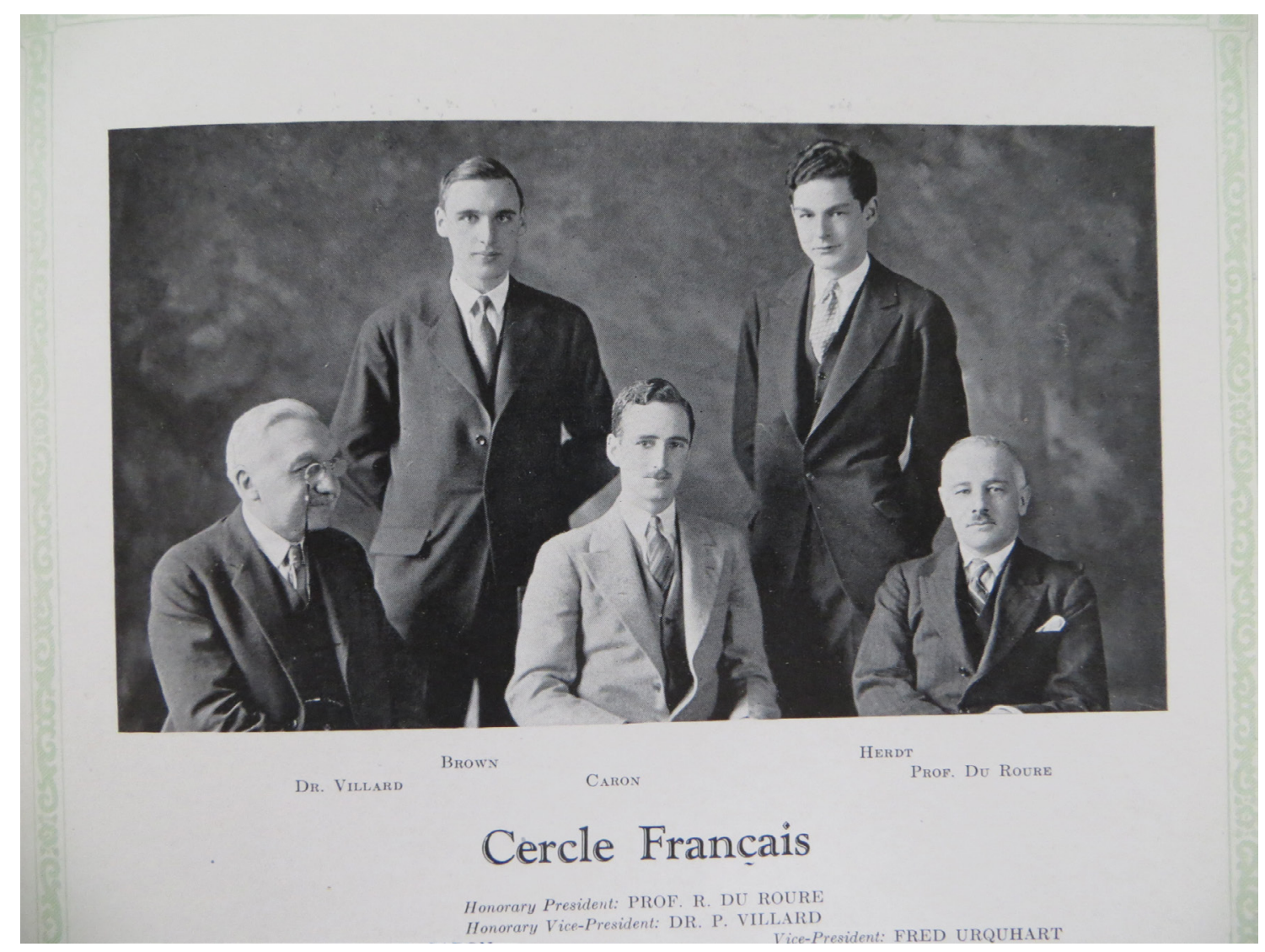

Figure 5. Le Cercle Français: Villard (L), du Roure (R), and student officers, Old McGill 1929, 203 
with a knowledgeable friend who said the form really existed. As Germaine left, the priest cried: -Reflect (adding what Messac declared showed his real motives): for you, my child, it will cost only sixty dollars! $!^{55}$ While Ralph Messac would have been only two or so, Serge Messac would have been perhaps five. According to Ralph's son Olivier Messac, the older boy was not sent to school during the family's sojourn in Montreal because Régis did not wish him to be exposed to the teaching of the Catholic clergy who ran the francophone schools. ${ }^{56}$ This rare glimpse of Messac's life in Montreal reflects his dislike of religion, which he must have felt was stifling the French of Quebec.

\section{Le Cercle Français}

The McGill Calendars have outlined Messac's teaching; the Progrès civique articles have revealed his reactions to America. Another source, the students' McGill Daily with its reports of meetings of the student club Le Cercle Français gives an idea of Messac's personality and dry humour - a nonfictional source to compare with Smith Conundrum's autobiographical portrait. Messac's informal contact with students in the Cercle contrasted with his protagonist's frustrations in the novel. The Cercle may have seen Messac's happiest moments on campus. The Cercle was open to all male students; the French Department staff served as animators (Fig. 5). Women students had the equivalent Société Française. The two groups met once each term for dancing and debates. The Cercle, founded in 1905, boasted that McGill, in the center of French Canada with a strong French department, was an ideal place to practice French. ${ }^{57}$ The Cercle held debates, some typical of college humour ("Are men the weaker sex?"58), others on serious economic and social issues. The Daily reported the Cercle's debates in more detail than it gave to the other 75 student societies, except athletics. Messac and his young colleague André Jean Roche sometimes teamed up to lead meetings. ${ }^{59}$ [Messac borrowed Roche's first name and middle initial, for his satire's protagonist André J. Pluche.] At Messac's first Cercle meeting on 15 October 1924, du Roure pointed out that McGill had high standards for teaching French and was the only English-speaking university where only French was spoken in classes. Messac was introduced "and he proved himself very entertaining with his first talk before this organization." He also suggested the first topic for debate: "Resolved that dancing is immoral," which he had heard debated during his year at Glasgow..$^{60}$ [Messac probably did not know Leacock had written about this chestnut in $1921 .^{61}$ ] The debate veered from the evils of jazz to the beauty of Pavlova's dancing. Messac and others gave (unrecorded) opinions and Messac, who was one of the judges, announced that they "felt constrained to present the palm to the affirmative, which had won on debating points." ${ }^{12}$ The debate even reached the editorial page of the Literary Supplement of the McGill Daily, edited by A.J.M. Smith, which advised that in view of the result Cercle members must not dance. The
Supplement, soon followed by the McGill Fortnightly Review (1925-1927), championed modernist poetry and leftish views. Messac may have had them in mind when he mocked the review Spirochetus in Smith Conundrum-although these publications shared many of his views, in particular, that athletes should be held to the same academic standard as other students. ${ }^{63}$

In other debates in late 1924 the Cercle carried the motion that "Professors are Indispensable at the University." Should railroads be privately or publically owned? An important question in Canada, with its huge spaces held together by rail; privatization won. Leacock, who usually attended one meeting a year, because of his interest in French and friendship with du Roure, suggested the topic "Is the pen mightier than the sword?" It was announced that "Dr. Leacock and Free Cigarettes" would draw crowds and that du Roure, Villard, Messac and Roche would lead the discussion afterwards. The Cercle decided the pen was stronger than the sword. One debater had remarked that Bulwer-Lytton, cited as the originator of the proverb that the pen is mightier, was a mediocre writer. ${ }^{64}$ Perhaps this inspired Messac to publish an article on Bulwer-Lytton in 1926, although Bulwer-Lytton also figured in his Detective Novel thesis. Leacock could not attend the meeting but later observed that debating topics like railway ownership had the good effect of forcing students to go to the library and read books. ${ }^{65}$ In February 1925 the Cercle decided "that we should prepare for war in order to prevent it." Messac and Roche addressed the meeting after the debate and their speeches were appreciated; one wonders whether Messac supported pacifism. ${ }^{66}$ Both men had served in the first war; both would be home in France during the second. At the Cercle's first Fall term meeting, in October 1925, "Messrs. Messac and Roche contributed a few entertaining words to the meeting and by that time the formality of the gathering had vanished...." ${ }^{n 7}$ The next meeting featured a lecture by $M$. Robert on the history of Canadian elections; afterwards, du Roure called on Messac and Roche to speak, "both of them contributing much to the merriment of the evening. The one with anecdote [sic] concerning Parisian elections, and the other with the relation of an incident on shipboard." 68

The fullest record of Messac speaking at McGill came out of the Cercle's debate on whether moving pictures were beneficial. Films brought up the issue of censorship, American influences and evil effects on the young. The Cercle's debate on 23 November 1925 probably helped spark Messac's chapter Film interdit par le censure in Smith Conundrum discussed later. It was announced that the program would include a talk by Messac: "Prof. Messac is well-known at the Cercle, and since his arrival at McGill has been a very hearty supporter. His address is sure to be one of interest, and will probably include some of his clever wit and humour." ${ }^{\prime \prime 9}$ The debate was won by those arguing moving pictures were harmful and that students should not attend them. A pendant to the debate, Messac's speech was "a very interesting and humourous talk on 'stage 


\section{WEATHER FORECAST GROWING COLDER}

Vol. XV., No. 47.

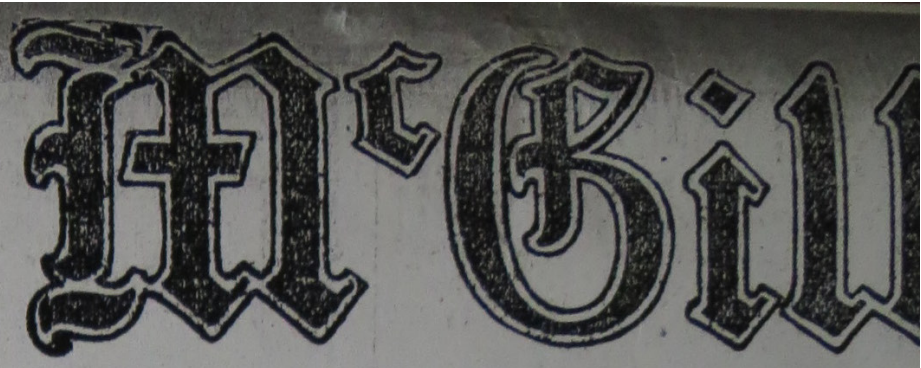

MONTRE

UNDERGRADUATES NOT TO ATEEND MOTION PICTURES

\section{Decision of Cercle rrancais in Debate}

\section{PROF. MESSAC}

Advice to Embryo Public Speakers on Stage Fright

Moving pictures are not beneficial to the public and are therefore not to be frequented. This was the decision rached by the Cercle Francaise ai a debate on the subject of motion pictures, last night. The affirmative was couragcously defended by Pemberton and Urquhart, while Jacques Herdt and Ray Caron carrled the negative on to victory. The question, however, was closely contested and winners had a very small majority.

Prof. Messac, of the French department was the guest of honour and Save a very interesting and humourous talk on "stage fright." He discussed matter in connection with actors ard public speakers, and concluded by giving some useful advice to novices in the art of public speaking.

The term "stage fright" was used express those emotions that seize inexperienced pub!.c speaker whes adessing a critical audience. This addessing a hower, cannot be taken definition, howerer, cansot even experword for word, because often been taken enced speakers have "le trac" This conw.th this emotion of le trac" amusedition might be a cause of at means ment for the audience but it meang
DR. PERRIN WILL DELIVER LECTURE

The subject of the second of the series of "Lectures on Approciation of Muslc" given by Dr. Perr!n, the Dean of the Faculty, is 'Italy and the Music of Corelli' Thilig Lecture which will be given on Wednesday evening, November 25 th at 8.30 p.m. in the $\mathrm{Hall}$ of the Conservatortium. ought to prove particularly interesting as it will be illustrated by lantern slides, as well as by the music of that composer. The lecturer will be assisted by Miss Kathleen Perrin and Miss Beatrice Earle (Violinists) and by $\mathrm{Mr}$. A. Goldberg (Violonceilist).

The course of ten lectures is open to the public at a fee of $\$ 5.00$ but the Fxtension Department wishes it to be known that anyone desiring to attend a single lecture may do so on payment of Fifty Cents.

\section{BLISS CARMAN GAVE ADDRESS ON FWE ARTS}

Showed Iheir Probable Development

\section{PRACTICAL USE}

Interpreted Selections from Browning and His Own

\section{Poetry}

'Poetry should express man's rela. tion to the unseen and the other world to God and the material of

\section{WINTER SPORTS ORGANIZE SOON}

Uuting Club Holds General Meeting Friday

The first general meeting of the McGill Winter Outing Club for the 1925-26 season will take place in the McGill Union next Friday afternoon at 1 ve o'clock, when plans will be discussed, and the organization for the year completed.

The season promises to be a busy one, and arrangements will be made on Friday concerning the entry of several McGill men in the Quebec w nter sports carnival. This will be held upon Dec. 30 , and a team from McGill will in all probabil ty compete. The famous carnival at Lake Plaod, on Dec. 30 , and 31 , will also see a group of Red-and-White competitors, $f$ present plans go through.

The Canadian Intercollegate $\mathrm{Di}$ visional Winter Sports Meet will be held $n$ Montreal on February 12 and 13, and the final interoollegiate meet about a week later in Hanover, the home of Dartmouth. These latter dates are rather uncertain, but the contests will be held about that time of the year.

If sufficient support is forthcoming. it is prabable that the Club will organize trips to the Laurentians over the weekends during the winter. These would be held at comparatively little cast, and would provide the average nember w th much unusual experience.

The executive of the club is very anxious that as many men as possible attend the meeting on Fr day, and first year men are especially invited to attend. Every skier, snowshower, and skater in MeGill is expected to 
fright.' He discussed the matter in connection with actors and public speakers, and concluded by giving some useful advice to novices in the art of public speaking." Messac's speech in French was summarized in English by the Daily (Fig. 6):

The term "stage fright" was used to express those emotions that seize an inexperienced public speaker when addressing a critical audience. This definition, however, cannot be taken word for word, because even experienced speakers have often been taken with this emotion of "le trac." This condition might be a cause of amusement for the audience but it means much embarrassment and suffering for the unfortunate speaker. To overcome it, a very practical suggestion was to speak plainly and simply, not trying to resort to words and language of any sophisticated nature. Prof. Messac remarked that this state of affairs is often present in students, especially at exam time. It was also pointed out that professors are in a position to derive much pleasure from such afflicted students, but McGill ought to feel very thankful that all the professors are of a much kinder nature.

An analysis of this emotion of "stage fright" shows it to come from a feeling of timidity which is in turn due to an attitude of inferiority. Now if this primary cause is eliminated the whole thing is done away with. Thus some more practical advice was to take on an attitude of superiority and leave no room for timidness and hesitation. ${ }^{70}$

One of the Cercle's avowed benefits was that students met their professors on an equal footing and as guest of honour Messac remarked on the 'en famille' atmosphere of the meeting. The winning debaters admitted that they actually liked movies. The Daily's editorialist, probably Leon Edel, used the debate result, headlined as "Undergraduates Not To Attend Motion Picture," to make fun of the Cercle's pomposity and presumptuousness just as the Literary Supplement had of the no-dancing decision. The editorial decried the poor quality of motion pictures: their "crude sentimentality, the abominable ignorance, the downright nonsense of most of the pictures produced to-day are facts to be greatly lamented." But if students participate in other low forms of culture such as dancing the Charleston then why single out motion pictures? ${ }^{71}$

The Daily next mentioned Messac in November 1926, when the Cercle debated professionalism and sports, a subject which Messac would develop in Le Progrès civique in August 1928, discussed above. The meeting voted that professionalism harmed sports. Discussion was lively: "Some very original opinions were expressed upon the subject, particularly by Professors Messac and McCulloch, who joined heartily in the argument."72 Paul McCullagh had just arrived as a Lecturer in Classics and attended the Cercle - he would stay at McGill for 60 years and possibly may have been a model for Addison in the chapter Honoris Causa in Smith Conundrum..$^{73}$ The related issue of sports at universities was debated hotly at McGill and elsewhere. In March 1927 the McGill Fortnightly Review, the voice of the literary students, argued that "one realizes the dangers of athleticism when Mr. Shaughnessy pats the professors on the back for not plucking a student because he turns out for the football team, and for being willing to give the football squad extra lessons to make up for lectures that have been lost through practices." ${ }^{74}$ In North America, university sports, notably football, conferred prestige and raised money from alumni. Frank Shaughnessy, McGill's famed football coach, was better known than any professor except Leacock. Some student critics declared there was too much emphasis on sports, that college sports were being carried on commercially to the detriment of learning, and decried the influence of the athletic director Major Forbes. ${ }^{75}$ Agreeing with this, Messac satirized Forbes ("Colonel Martlet" in his novel) and sports boosterism at McGill generally in his chapter Le Rah Rab Boy. The Daily last reported Messac in late February 1928. Du Roure had spoken on economic conditions in France and mentioned that French student organizations did not work well. "Discussing the reasons for this, it was suggested by Professor Messac that it was due to the tendency of the Frenchmen to be individualistic." ${ }^{76}$ Although Messac was elected the Cercle's honorary vicepresident for 1928-1929, he is not mentioned as present at meetings. It seems likely that his enthusiasm displayed from 1924 to 1927 had declined as he concentrated on finishing his thesis and, perhaps, became more disenchanted with McGill. And Germaine was pregnant.

\section{SMITH CONUNDRUM}

\section{Introduction}

The college fiction genre became increasingly popular in America in the 1920s as enrolments increased and this golden stage of young peoples' lives seized the imaginations of writers like Scott Fitzgerald. Messac's caustic novel from a professor's viewpoint contrasts with two other evocative visions of McGill in fiction: Dink Carroll's unpublished novel about a football-playing fraternity student of the same era (1920s) and Norman Levine's nostalgic siftings of his student experiences of the late 1940s. ${ }^{77}$ Even more than Carroll and Levine, Messac drew on the specific character of McGill at a certain time: its staff, events and architecture; unlike them and most others writing about McGill, he made little play of the alluring Montreal setting. [McGill must be the most frequently mentioned Canadian university in fiction. I have found at least 800 novels and stories with passages on McGill, dating from 1870 to the present. In at least 50, student or faculty life plays a major role.]

Smith Conundrum is the fictional side of Messac's "American" journalism which we have seen in Le Progrès civique: the 
novel continues the same themes-snobbery, stupidity, hierarchical rigidity, and fascination with measurement and technology not real knowledge. The novel began appearing as long vignettes in Le Progrès civique in 1928 while he was still at McGill, under their own chapter titles and in their final form, but not yet ostensibly as a novel titled Smith Conundrum. ${ }^{78}$ He probably considered the chapters as part and parcel of his other writing on America for Le Progrès civique-but more fun!-and may not have planned a full novel until more chapters had accumulated by 1931. Although announced in 1935, with the complete title Smith Conundrum: roman d'une université américaine, the book only came out in 1942, in German-occupied France. Most copies were destroyed in the war, by the Germans on purpose and the American army by accident. ${ }^{79}$ Marc Angenot of McGill's French Department discovered the novel in 1975 and identified the "American" university as McGill..$^{80}$ The novel was republished in 2010. As Angenot notes in the 2010 preface, French readers would not have been interested in Canada or Quebec but were very interested in America. Likewise, having to recreate the real life setting of Quebec with its language and national issues would have distracted from the self-contained world of the university which Messac wished to portray. ${ }^{81}$ Accordingly, Messac located Smith Conundrum in the American state "West Washingtonia" in an unnamed city. The novel was subtitled roman d'une université américaine both when it was announced on the forthcoming list of la Fenêtre ouverte in 1935 and finally published in 1942 and reprinted in 2010 (Fig. 7). Internally, the text reads as set in the United States. However, when the chapter l'Académicien was published serially in 1931, the brief editorial introductory note [not by Messac, presumably] revealed that the action of that chapter takes place "dans une université canadienne." 82

The novel challenges us to detect the events and people that inspired Régis Messac. What is real, what is invented? Only by knowing the context, can we see how closely Messac turned his daily routine into striking satire. Unlike Leacock's college satire, which seldom had real life back stories, Messac's rather convoluted and involved plot, especially the later chapters, can only be appreciated fully if one knows what personalities and situations he and his protagonist were

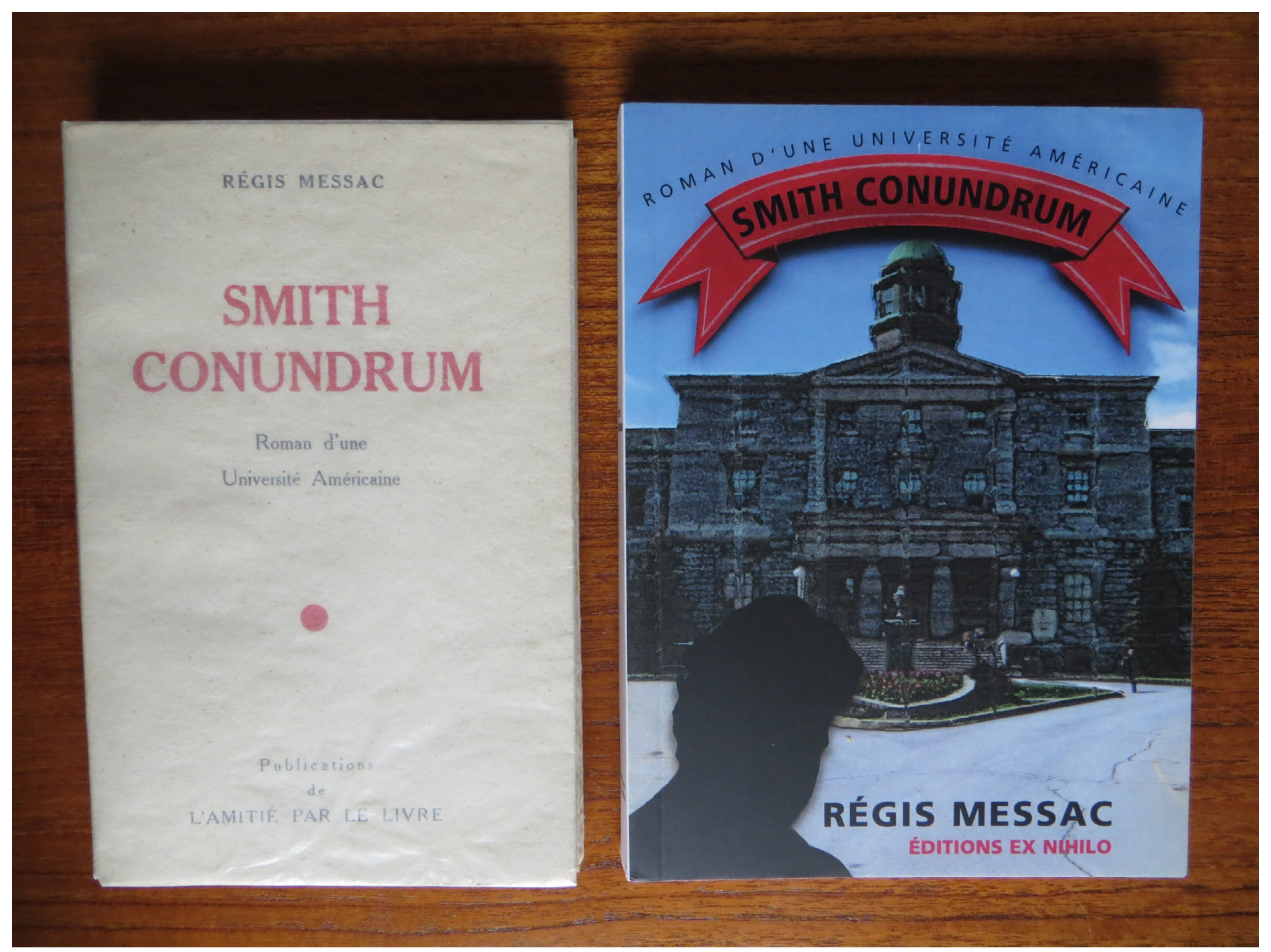

Figure 7. Smith Conundrum: covers, 1st edition 1942 (L), 2nd edition 2010 (R) 
reacting against. Messac, who loved leaving clues, might have enjoyed the present article's exercise in detection. The novel's 35,000 word text is in French, told in past tenses. Each chapter is a vignette of academic life with seasonal changes but not strictly following the academic year. Some of the chapters represent the timeless absurdity of academic life, others were inspired by specific events during the five years that Messac taught at McGill (Pluche was at Smith Conundrum for four years not Messac's five). It is a unique take on McGill from the viewpoint of a discontented assistant professor. We know the thoughts of Messac's alter ego André Pluche; his scholarly and anti-hierachical attitudes resemble Messac's in Le Progres civique but are milder, more naïve. Pluche slowly learns he cannot instill scholarly knowledge where incompetence and indifference to learning rule. While Messac gives no dates, he refers to Prohibition, bootlegging, Lindbergh (1927) and the Kellogg Pact to outlaw war, signed 27 August $1928 .^{83}$ Messac wrote most of the novel from 1928 to 1931 while McGill was fresh in his mind. The novel still awaits English translation. ${ }^{84}$

Messac's protagonist is a newly hired professor of French, AndréJ. Pluche. The name Pluche probably reflected Messac's admiration (as a scholar of popular literature) for the science popularizer Abbé Pluche (1688-1761). ${ }^{85}$ A quietly ironical slightly naïve version of Messac, Pluche closely resembles his creator; he is short, dark with anti-establishment views. ${ }^{86}$ Pluche talks to himself; did Messac? Pluche unlike Messac is single-this lets the plot focus wholly on his university life. Pluche and Messac are both preoccupied by research for their PhDs. Pluche lives on the fourteenth floor of the "California Building." Messac loved dropping twisty literary allusions: Sinclair Lewis's Babbit (1922) was glad that his own office building, also fourteen stories high, was three stories higher than the "California Building" in downtown Zenith, U.S.A. ${ }^{87}$ Pluche's high rise residence also may have been inspired by the ten story Maxwelton apartment building facing the McGill campus. The campus with its "Gothicocorinthienne" architecture matches McGill for the most part, down to what Pluche/Messac saw as the fake gothic of Presbyterian College (Morrice Hall) and the new-world attempt at cathedral stained glass windows in Redpath Library. Many characters, circumstances and events can be traced to real ones. Like McGill, Smith Conundrum is named for its wealthy founder; like James McGill (1744-1813), Smith Conundrum is buried on campus under a stone urn (Fig. 8), and like the Scot McGill, who made a fortune on the fur trade, the Welsh-born Conundrum also had made his money on animals - but on their entrails not their fur. Pluche enters Smith Conundrum's campus through recently built monumental stone gates which cost \$50,000; the new Greek columns of the Roddick Gates, built during Messac's first year at McGill, cost exactly the same. ${ }^{88}$ Yet Pluche has just been refused a paltry $\$ 45$ dollar annual raise. Messac would have received the then standard McGill salary for assistant professors of (CDN) $\$ 2,500$ : liveable but not the $\$ 4,000$ to
$\$ 5,500$ of higher professors. In 1926 when a $15 \%$ pay rise was in sight, Ira MacKay, Dean of Arts, suggested to Principal Currie that it would be better to increase the salaries of the principal men in departments rather than fritter funds away "on minor men teaching minor courses." ${ }^{\text {"In 1927-1928 }}$ McGill had 83 full professors, 34 associate professors, 68 assistant professors and 93 lecturers. ${ }^{90}$ There was a strong division between full and associate professors and the more lowly assistants and lecturers. Pluche like Messac felt trapped by low status and low pay.

\section{Messac, Leacock and McGill Satire}

Pluche carries a book titled English style explained through Army secret Codes "by a Chicago professor." This and Pluche's Ph.D. thesis under way for University of Chicago are Messac's sly homage to Leacock who wrote his Ph.D. at University of Chicago (under that scourge of business influence in America, Thorstein Veblen). Messac even cited Leacock's Nonsense Novels in his thesis as parodies of the detective genre. ${ }^{91}$ Leacock was McGill's best known teacher and a great friend of du Roure. While there is no written evidence, ${ }^{92}$ Messac would have known Leacock and must have been influenced to some extent by his satirical writing on McGill and universities in general. Messac and du Roure had their students translate Leacock's nonfictional bestseller

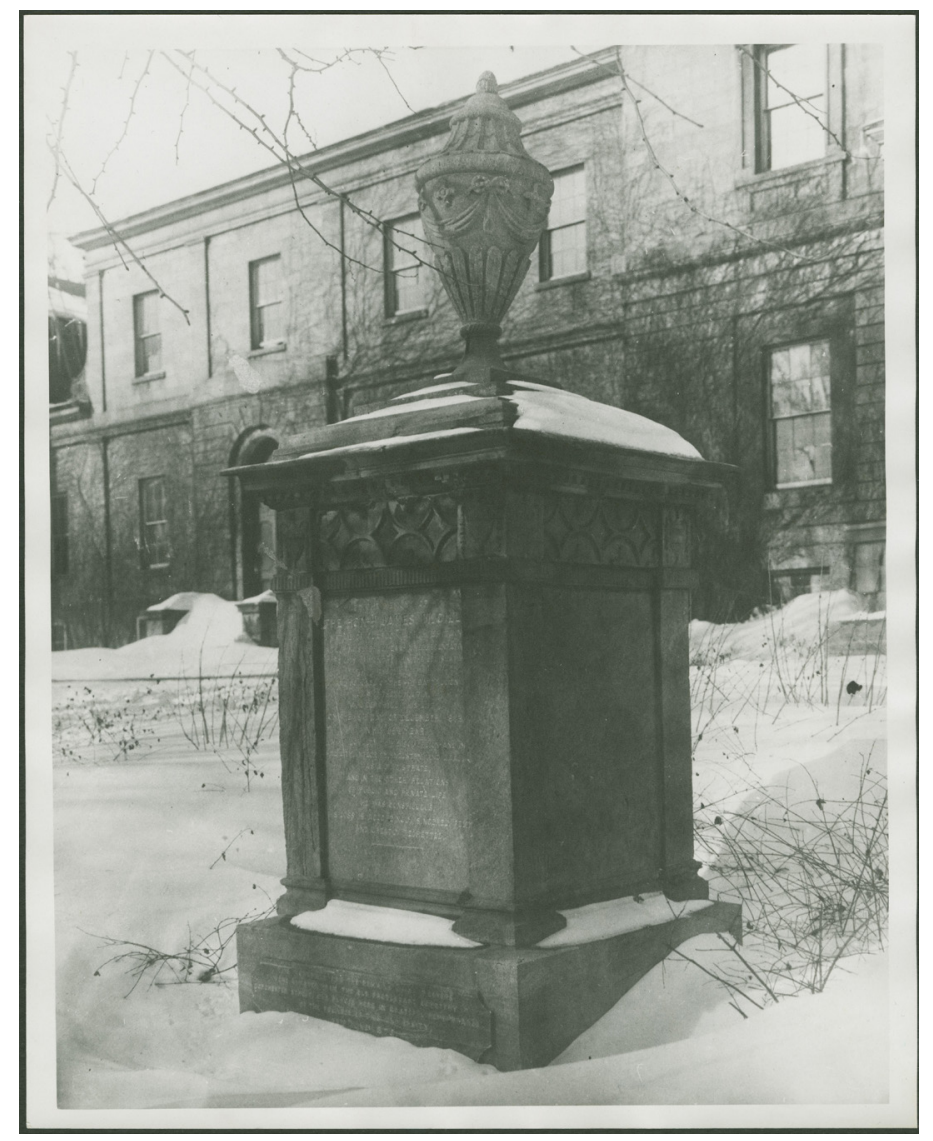

Figure 8. James McGill's tomb, Arts Building, ca. 1925, photographer unknown, MUA PR012450 
My Discovery of England (1922) as exercises for their courses so Messac would have known that book's satirical comments on American university education and agreed with them. Both Leacock's and Messac's satire partly originated from their social criticism and contempt for religious enthusiasm, Bible colleges, teetotalism, puritanism, pseudo-scientific intelligence testing, and from their distrust of unrestrained capitalism and money's power to influence universities. Like other critics, they loathed the American elevation of business efficiency and social skills to academic status. Leacock satirically had advised Oxford to copy North American universities, have courses in salesmanship, and seek wealthy donors. He cited Chicago's oil money [Rockefeller's] and McGill's tobacco money [Macdonald's]; Oxford should also imitate the American practice of selling honorary degrees to millionaires. Messac excoriated all these practices, not in his novel but in his article "Bunk."93

By the 1920s, as Messac could not have helped realizing, Leacock had established himself as the standard of satire (both fiction and nonfiction) on universities in general and McGill in particular. Messac's satire is more biting and pessimistic than Leacock's gentler tone and has a dose of malice towards lazy students and incompetent teachers not found in Leacock. Perhaps this reflects their different positions as icon and junior professor. Yet although edgier, more detailed, Smith Conundrum falls into the tradition of Leacock's satirical college fiction. Leacock's best known one was a section of Arcadian Adventures Among the Idle Rich (1914), set at Plutoria University, recognizably McGill but located vaguely in the United States - for better sales, just as Smith Conundrum would be for greater attraction to readers in France. Unlike Arcadian Adventures, however, Messac's entire novel is about university life and and has more sustained focus than Leacock's on the protagonist's character, which develops (mainly through disillusionment) as the novel progresses. Though both depended on loosely connected episodes, Messac wrote a novel, Leacock stories. Messac did not name McGill while Leacock often did, in his essays, poems, and skits. Leacock wrote many works making fun of college life; Messac just one. Leacock's situations are often more absurdly fanciful than Messac's - in his long story (1932) "Rah! Rah! College," Tom Buncom, at the American Shucksford College which has given up lectures to allow students more club time, majors in dog-walking. ${ }^{94}$ Messac's satire was more obscure, private, and drawn from real circumstances; it is less easily and universally accessible, less fun-loving and whimsical, than Leacock's. Messac kept to the real and plausible. While Leacock based characters in Sunshine Sketches of a Little Town (1912) on real people and President Boomer in Arcadian Adventures resembled McGill Principal William Peterson, most of his characters, if they existed, bore few descriptive clues and are untraceable. Much more than Leacock, Messac derived many of his characters and episodes from traceable McGill originals and in sharper, more unflattering detail.
He usually started with real people, even if the point of resemblance was merely something such as old age (like Dean Bunk/ Ruttan, called senile in Honoris Causa, below) and not developed further. Yet a few of Messac's characters, Professor Talkinghorse for example, seem as purely invented as any of Leacock's. Both satirists invented funny names: Messac's Deans Heluva, Cattle and Bunk vie with Leacock's Dean Dump and Rev. Mumble in "Rah! Rah! College." Both Messac and Leacock satirized female students in particular; both mocked dim students, business influences, and the teaching in academe of subjects like salesmanship or hygiene. ${ }^{95}$ While their satire (and indeed most college satire) was similar, their personalities, politics and circumstances differed greatly. Twenty-four years older, Leacock was the reigning "character" on campus, an imperialist and conservative (with a streak of "red Tory" ${ }^{\text {"96 }) . ~ M e s s a c ~ w a s ~ l o w ~ o n ~ t h e ~ t o t e m ~ p o l e, ~ l e f t i s t, ~ a n t i-~}$ war, anti-hierarchy, and anti-religion. Leacock was happy at the "American University," Messac probably was not.

\section{La fille de Peudzippah}

Following Pluche through the chapters of Smith Conundrum, we progress from the early light ones to later gloomier, didactic ones. Pluche starts naïve, finishes cynical. Occasionally Messac's phrases will be loosely translated and integrated here to convey his style. ${ }^{97}$ Pluche enters the main building, based on the McGill Arts Building [where Messac's office and classrooms were], refurbished in 1925-1926 with shining marble and double ranks of stairs. He tries to teach his class the beauties of Racine's Phèdre. Miss Bloomfield valiantly mispronounces the name of Phaedra's mother, Pasiphae, as "Peudzippah." [Messac ridicules the students' French-and English - accents mercilessly.] Horrified to discover the class knows no classic myths or ancient history, Pluche blames the chairman of the History Department, Alexander Snuffbox, Ph.D., whose thesis of only 59 pages was on "George Washington's Tactics at Great Meadows." Snuffbox matches History chairman William T. Waugh, an expert on James Wolfe, conqueror of Quebec..$^{98}$ Not surprisingly, Messac Americanized Waugh's Wolfe into Snuffbox's Washington. Besides the satirist's usual exaggerations, Messac may have mistrusted Waugh for his friendship with Principal Currie and for his grandiose 41 day tour of Canada lecturing on Wolfe in 1926. Pluche asks if the class knows what Greece is. Miss Calvinson replies, it is a little country in Europe... there are ruins. Pluche gives them a quick history of Greece, the Trojan War, but to no avail. Harry Swellhead, a football player sneers. When Anita Loveduck starts doing her lipstick, Pluche knows his lecture hour is up. Swellhead and Loveduck represent hormonal indifference to learning. Outside after class, Pluche is nearly run down by a huge car driven by Swellhead, with his arm around Loveduck, and imagines his death written up in the Smith Conundrum Daily. Messac captures the freedom which McGill and American students enjoyed. University culture in Canada and the 
United States was similar. The McGill Daily discussed kissing and "petting." Students owned cars, courted, joined one of the twenty fraternities and dozens of clubs, dined in the cafeteria of the student union, and cheered at football and hockey matches. The Smith Conundrum girls wear furs and "kiss-proof" lipstick (favoured by both sexy Anita Loveduck and cerebral Goldye Belemnith). Were the students as dim as Messac portrayed them? Some McGill students, like Frank Scott and Maysie MacSporran were brilliant, some were not. Apropos, the McGill Annual Report of 1924-25 complained that many students could hardly write, quoting hilarious illiteracies - which may have inspired Messac. ${ }^{99}$

At the end of the chapter, when Pluche plans to flunk Swellhead, "Père Dubois," a father-figure and older professor of French, explains the facts of life to Pluche (there is a camaraderie among the few Frenchmen at this "American" university). Dubois warns Pluche that Swellhead as an athlete is too important to be sacked and besides his father is a Senator. [As already noted, at McGill it was often complained that professors were unwilling to fail athletes, since that would disqualify them from competition. Messac agreed with this complaint; indeed, he published this chapter in Le Progrès civique in September 1928, only a month after his attack in the same journal on America's sports professionalism. As usual he made the same points in his novel as in his journalism.] Père Dubois appears in nearly every chapter, far more frequently than anyone else but Pluche himself. He is friendly, unflappable, a foil for Pluche, whom he advises to conform to the low standards and social obsequiousness of the University. Superficially, he matches the popular Associate Professor Paul Villard (1867-1952), a Frenchman who had graduated from University of Paris in 1887, had ties with French organizations in Montreal (he was Secretary of the Alliance Française), was a Protestant minister (hence "Père"?) and held a medical degree from Bishop's University. ${ }^{100}$ Dubois and Villard are both viellards with white hair. Villard had charge of French courses for Commerce students; they called him Papa Villard (hence "Père" again). Villard was the highest in rank after du Roure-he had been promoted to Associate just before Messac arrived in 1924. At this point, it should be emphasized that the novel was a satire. Like most satirists, Messac used details from real people to create fictional characters. Personality flaws and quirks were inflated or created for effect; the characters took on their own lives. While Villard, du Roure, Principal Currie and others initially inspired Messac's characters and resembled them in appearance and other circumstances, one cannot know if they ever acted and spoke as their fictional shadows are portrayed. Presumably Messac took the usual authorial liberties of simplifying, exaggerating and inventing. Though not considered a specialist, Villard was judged " a very useful all-around man." ${ }^{101}$ Villard, du Roure and Currie played important roles-but they could not claim to be innovative scholars and their positions above Messac made them fair game for parody - as Père Dubois, des Boys de la Tour and Rumblebass Balderdash respectively .

The description sof students, staff and architecture all match McGill's. While the initial inspirations for Pluche's fellow professors can be traced to real people (see Appendix), the students are archtypes (dim, talkative, rich, athletic). If they were based on real students there is no way to identify them. Pluche's students are from the mixture of races Messac found at McGill: English, Scottish, Irish, French, Jewish, German, East European and Italian-blue eyed Gretchens, athletic Scandanavians, and even a Japanese. ${ }^{102}$ Rivaling Shakespeare and Dickens, Messac invented names and characters were born! Calvinson, Pilgrim, Bloomfield, McRaevity evoke Smith Conundrum's (and McGill's) ethnic variety. Other names conferred personalities: Harry Swellhead, Pixie Pickering and Rumblebass Balderdash, while Prosper Doughnut, Anita Loveduck, and Lord Pyff are delightfully fanciful and Colonel Martlet suggests martinet. ${ }^{103}$ Messac had a sharp ear for both slang and formal English. His letters in English between 1928 and 1939 to Thomas Mabbott, C.K. Ogden and David Keller (he translated the latter's science fiction into French) were clear and grammatically correct. ${ }^{104}$ Some of the novel's names probably were adapted from the names of real people-perhaps both Pluche's department chairman des Boys de la Tour and Père Dubois from a student, R.M. DuBoyce (B.A. 1928, B.CL. 1933), whose paper Messac took back to France. ${ }^{105} \mathrm{Du}$ Roure's aristocratic family was des Royes (or Roys) du Roure ${ }^{106}$ so the fictive chairman's full name "le vicomte des Boys de la Tour" (hereafter des Boys) plays on that as well. Messac gave English characters amusing names, such as Joshua Heluva for a Dean of Theology, while French characters often had inflated, aristocratic names.

\section{Le Professeur Talkinghorse et l'idée de genie}

Pluche goes to the Library, walking quickly so he will look efficient and American. He reviles its stained glass [Victorian gothic Redpath Hall] as worse than Lourdes or the Woolworth Building, and sees students comatose after drinking "hooch whisky" all night. In the library he sees Cadwallader H. Talkinghorse, M.A. Ph.D., Parsley Professor of Ethics and Moral philosophy who has long legs, wide shoulders and an equine profile. Talkinghorse is measuring the lengths of articles in the Encyclopedia Britannica in order to discover the relative importance of historical figures. $\mathrm{He}$ has made a list of measurement results: Galileo scores impressively at $1.35 \mathrm{~m}$ while Napoleon scores $2.50 \mathrm{~m}$; Nelson $3.25 \mathrm{~m}$ and Dante $1.23 \mathrm{~m}$. Pluche shatters his colleague's method by pointing out that he must take the language of his encyclopedias into consideration: English and Italian encyclopedias will differ as to the relative lengths they give Nelson and Dante. Talkinghorse checks. The Italian encyclopedia gives Dante $4.75 \mathrm{~m}$ and Nelson only $0.33 \mathrm{~m}$. Poor Talkinghorse drops his research; Moral Philosophy will 
not make the advance he hoped for. Talkinghorse's ponderous name, endowed professorship and earnest simple mindedness typify Messac's idea of the American academic. In name and title, Cadwallader Talkinghorse, Parsley Professor of Ethics and Moral Philosophy resembles Dr. William Caldwell, Macdonald Professor of Moral Philosophy, 1904-1929, campus eminence, personality and speaker on foreign affairs who, with Leacock and others, helped introduce Chicago School sociology and social work studies at McGill. However, Talkinghorse's nonsensical research seems purely invented, to symbolize the American obsession with measuring and testing or even to swipe against data-collecting research methods of Chicago, where Caldwell had taught briefly. ${ }^{107}$

\section{Graeculus Esuriens I, II}

This two-part chapter develops the theme of dim students and Dubois' advice that they must not be failed, especially if they are from important families. Snow falls as Pluche corrects examinations in his overheated attic office. The French Department rooms are cramped to give Talkinghorse a large suite to arrange his research files. Enter Dubois. Pluche groans that he has 341 exams to correct. He must read the same dull answers about the history of France and Maupassant's necklace story 341 times! He reads Dubois the answers written by Goldye Belemnith; she has mixed up her fictional with her historical readings. Sad isn't it? Pluche asks. Terrible, replies Dubois. What do you think it is worth? asks Pluche. Indulgence is our rule here, says Dubois. You can't mark these girls like French ones. Pluche suggests a mark of 48 out of 100. Dubois fidgets. Do you realize Goldye is the niece of Bishop Exeter Belemnith, the brother-in-law of our Dean? Then should I give her 75 ? asks Pluche. At Columbia University, says Dubois, they seldom give less than 95 . [Columbia was a centre of French studies; Baldensperger's colleague Paul Hazard gave a far happier report of its students in the 1920s. ${ }^{108}$ ] Understood, says Pluche; Smith Conundrum must not be left behind. Pluche muses on his own very different education at the Sorbonne: I learned Latin. He tries to recall a line he learned from Juvenal. You're not at the Sorbonne, declares Dubois; you cannot treat Goldye like a sorbonnarde. I'll give her a 98, says Pluche. Now you're being reasonable! says Dubois. Pluche recalls the line from Juvenal: Graeculus esuriens ad caelum jusseris ibit! Pluche is probably comparing his own circumstances to the hungry Greek scholars who performed all kinds of servile services to survive in the Roman Empire - the Smith Conundrum professors are Greek slaves, the students their Roman masters. ${ }^{109}$ [In 1933 Messac would scandalize traditionalists with his book A Bas le Latin! ${ }^{110}$ Whether he was ever pressured at McGill to mark gently is unknown.]

Two days later, a girl comes into Pluche's office. Muskrats have been sacrificed to cover her from head to foot: she is as pretty, bold and banal as a cigarette advertisement. She is
Goldye Belemnith to whom Pluche gave a 98 after prodding by Dubois. Her French stumbles. "Prof'sieur Diouboisse ma dit... told me how nice you were." Pluche offers to speak English. ${ }^{111}$ She replies she can speak French and that she is a "pouate," She even writes verse in French. Better and better, says Pluche. Goldeye tells Pluche she has founded a bilingual literary journal, The Spirochetus (Bacteria!). Messac was mocking the McGill Daily Literary Supplement and its successor the McGill Fortnightly Review, run by iconoclastic student writers A.J.M. Smith and Frank Scott; Messac's invented Spirochetus probably alluded to the Literary Supplement's controversial publication of an Aldous Huxley verse on "spermatozoa." ${ }^{112}$ Ironically, if he had not been writing satire, Messac would have approved of these journals, which aired socialist and anti-war views, and criticized the orderly, conservative, hearty, sports loving university of Sir Arthur Currie. ${ }^{113}$ Thanks to Pluche's first class grade, Goldye will do a master's degree. Since she is interested in both Mallarmé and Freud, she proposes a thesis on Mallarmé, explained by Freud. Splendid, gasps Pluche. ${ }^{114}$ As she leaves, refreshing her kissproof lipstick, Goldye says Pluche does not deserve his reputation d'ours (perhaps a play on the plush [peluche] of which toy bears were made). Maybe Messac thought his students found him grumpy and demanding.

\section{Film interdit par la Censure}

Dubois invites Pluche to a private screening of a film based on Corneille's Le Cid, before any cuts are made by the censors. Does the film have naked women? asks Pluche. Dubois replies that the film is more likely to be censured for political reasons. Dignitaries will attend, including le Marquis du Quartier de Montrouge of the French consulate who also (strangely) happens to be on the local board of film censors [the real life Consul was Baron Régis de Vitrolles-another aristocratic title for Messac to improve on]. Pluche and Dubois meet at the Princess Theatre [which really existed; Houdini performed there on 22 October 1926, was afterwards test-punched by a student apparently registered at McGill, and subsequently died. ${ }^{115}$ ] The fictional audience includes representatives of the Association for the Protection of Women and the Home as well as consular officials from Spain and France.

The film is Messac's rewrite of Le Cid as a Hollywood western set in Texas, full of complicated pranks, violence and murder. Messac casts Charlie Chaplin as the hero El Cid Campeador, renaming him "Syd Camp-eater." After the film is shown, Joanna Marplot, Miss McThormy and Reverend Minus Habbins, boiling with Anglo-Saxon outrage at indecency, demand the film be censured because its plot and Chaplin are both immoral. For their part the French and Spanish consular officials storm against the film's insults to their national honours. All agree the film must not be shown. The manager of the Princess accepts this philosophically. He 
will screen a Cowboys and Indians western instead. The farce is complete.

Messac liked the subject of films; in parts of the novel Pluche watches events unfold as if in a film or drama. Messac had fun pastiching a classic and attacking censorship, puritanism and nationalism at the same time. ${ }^{116}$ Overlapping as he often did with his Progrès civique articles, Messac also used "minus habbins" to personify the illiterates who easily gain titles and prestige from American institutions. ${ }^{117}$ The chapter's women are modeled on the English Montreal reformers of the 1920s who tried to abolish vice in the "Paris of North America." Messac also may have been inspired by the Cercle's debate on films, already discussed, or by the presentation of Corneille's Le Cid at McGill in November $1928 .{ }^{118}$ Moreover, in the mid-1920s it was well known at McGill that Stephen Leacock was being courted by Charlie Chaplin as well as by Douglas Fairbanks and Mary Pickford to write screen plays for them. ${ }^{119}$ Finally, Messac taught Le Cid in his courses. With these McGill stimuli, this chapter on Le Cid and Chaplin seems inevitable!

\section{Jamais Content}

The elegant, unflappable head of the French Department, vicomte des Boys de la Tour is modeled on the aristocratic René du Roure, Chairman of the McGill Romance Languages Department, 1923-1940. ${ }^{120}$ Pluche gives his own courses between 9 and 11 in the morning. This leaves him the rest of the day to work on his Ph.D. thesis-whether Messac's schedule gave him the same free time is unknown. Consequently, Pluche seldom sees des Boys who, like his real life model du Roure, never arrived on campus before 11 a.m. Now they are to meet in in Room 345 of the Arts Building ${ }^{121}$ to give oral examinations together. [McGill students in French took both written and oral examinations.] If I am late, start without me, des Boys tells Pluche. Dubois warns Pluche that he must remember that des Boys never fails students. JAMAIS! The only exceptions are the occasional female students, but only if they are ugly as well as without relatives or protectors. A nice young girl has only to bat her eyes or weep-des Boys cannot resist the tears of a woman. And fortunately for the ugly ones, they usually work hard and are among the best students.

After Pluche has examined three students, des Boys shows up at 11:15 still sleepy. They quiz Kathleen McRaevity about the plays of François de Curel. Pluche has heard of McRaevity. With Joanna Marplot, the film censor, she is active in morality societies trying to shut down the red light districts. Miss McRaevity calls Curel "Curnival" (and "Carnival") and his "Le repas du lion" lei repast dou laieunn. Pluche's mind wanders while she delivers platitudes. Worse, he notices des Boys has fallen asleep and is snoring. Should Pluche wake him? Dubois had not warned him of this! When McRaevity starts talking about "Curnival de la Chausée," Pluche realizes she must be confusing Curel (1854-1928) and Nivelle de la Chausée (1692-1754). While Pluche wonders what she knows about the prostitution her group is suppressing, Miss McRaevity declares the hybrid "Curnival" wrote indecencies, about subjects which were unthinkable, she says lapsing into English. When she leaves, des Boys wakes up. Pluche asks: What did you think-Pas fameuse? That's just like you, retorts des Boys; it was fine, what she said, cette petite. But you, Pluche, vous n'êtes jamais content! Miss M. gets the top grade.

Messac sketches des Boys/du Roure's mannerisms deftly but (as this is satire) not his accomplishments. Du Roure built up the famous French Summer School and tenaciously lobbied the Dean of Arts for extra help for his overworked department. He advised the Consul General of France in Montreal on "Franco-Canadian questions connected with university and artistic work;" he wrote a survey on the teaching of French for the Protestant (English) School Board of Montreal in 1931 and, supported by Leacock, tirelessly advocated the establishment of a Maison française at McGill. ${ }^{122}$ And while du Roure did little scholarly publishing, he wrote several lively articles including an unfavourable review in 1922 of Lionel Groulx's nationalistic novel l'Appel de la race. Du Roure declared the novel encouraged racial discord, pointing out that one of the repentant FrenchCanadian hero's youthful crimes was that he had studied law at McGill, not a francophone university. ${ }^{123}$ Though he satirized du Roure, Messac liked the man who had hired him and had reason to be grateful to him. While des Boys frustrates Pluche, du Roure supported Messac's research in France by teaching his courses in October 1926 so that Messac could return late. ${ }^{124}$ Messac inscribed a copy of Le 'Detective Novel' to du Roure with melancholy but affectionate irony, recalling their teaching and examining together: "A Monsieur René du Roure / Hommage de l'auteur / In Memoriam / Régis Messac."125 And in its preface, Messac thanked "mon chef et ami M. René du Roure, qui m’a accordé toutes facilities au cours de mon travail...." Clifton Hall (M.A. McGill 1932) recalled du Roure: "was essentially a Parisian gentleman, his manners perfect, and always dressed with the greatest care.... A ray of sunshine from the Paris boulevards brightened the room as René came in bowing to his students, Bonjour, mesdemoiselles, messieurs. He preferred French writers of the sixteenth and seventeenth centuries to all others." 126 It was said du Roure died of a broken heart after the fall of France in $1940 .{ }^{127}$

\section{Les livres}

This chapter is about a subject dear to Messac-ordering books for the library. Pluche needs books for both his teaching and his research for his thesis. Pluche, like Messac, is writing a Ph.D. - but for Chicago and on a far more obscure topic than Messac's: "L'expression du lugubre dans Zschokke." [Messac's 
real thesis Le 'Detective Novel' has a brief reference to this German writer who set some of his fiction in America-New Orleans! Messac delighted in this sort of interplay between his real and fictional life.] Pluche has given des Boys a list of books to have the library order. They have not arrived. Why order books? asks Père Dubois; I prepare my courses with the encyclopedia. Des Boys apologetically pulls the forgotten list from his pocket. Pluche takes it to the library. The head Dr. Godwin is away at a librarians' conference but an assistant takes Pluche's list. She is immensely impressed; he has ordered even more books than Talkinghorse. The titles Messac has Pluche order reveal how closely Messac used real life details in his novel. Pluche asks the Library to buy "Hoxie Fairchild, The noble savage", "G.H. Luquet, la Religion des hommes fossils", "Ferand, Introduction à l'astronomie nautique arabe" and three other titles. Later he adds others including "Victor Hugo et Rosita Rosa" and "Victor Hugo spirite." The latter two related plausibly to the courses that Pluche/Messac taught-the others were rather esoteric and possibly to be checked for his Detective Novel thesis-or just seemed interesting. Of the ten titles specified in the chapter, eight had editions ca. 1925-1929 and appear in the catalogues of the Bibliothèque nationale de France; only the Hoxie Fairchild book is listed in the McGill Library catalogue today. At any rate, these book titles provided a jeu for Pluche-Messac interplay. ${ }^{128}$

In real life, Messac ordered books even more energetically than Pluche. Aided by the head librarian Dr. Gerhard Lomer, Messac requested the Library to purchase numerous works on French literature and other topics for his own thesis research and for reading by his students. ${ }^{129}$ Messac borrowed the books he ordered and others in the Library non-stop. In 2003 sixty-five books still had Messac's signature on the borrower's cards inside their covers-a fraction of what he read, considering this sign-out system had ended 40 years earlier and nearly all the cards had been discarded or lost as the paper slots holding them wore out. Of the books with surviving cards, signed out between 3 December 1924 and 27 April 1929, eight were by Balzac (Figs. 9\&10). Unlike Pluche, Messac devoted a course to him; Balzac figures largely in his thesis as well. Other titles show Messac's political or research interests, such as Joseph Reinach, Histoire de l'affaire Dreyfuss and a book by his thesis director Fernand Baldensperger. ${ }^{130}$ Messac borrowed books by Bulwer-Lytton and Anatole France, probably for the articles he published on them while at McGill. It is difficult to tell how many books Messac had the library order but of the 65 he signed out on the surviving cards, there are 17 which were acquired during his time at McGill and on which his signature was the first-an indication he may have ordered them. ${ }^{131}$ Besides books from the Library and borrowing detective novels from Professor Hermann Walter, Messac bought books by mail: the Assistant Bursar of McGill informed him of the arrival of some novels in December $1927 .{ }^{132}$ Likewise, writing to the Poe scholar Thomas Mabbott in 1928, Messac mentioned how hard it was to get periodicals which the McGill Library did not have, and how the inept Montreal booksellers had failed to get him a journal he wanted. ${ }^{133}$ Messac acknowledged Lomer's help in the preface to Le 'Detective Novel' and inscribed a copy to him: "To Dr Lomer as a testimonial of my gratefulness \& friendliness R. Messac."134

\section{Le Rah-Rah-Boy}

Prosper Doughnut, a student, is eating that most American concoction, a sundae-whipped cream, bananas, pineapple chunks, water melon, plums, figs and a date on top. Cherries, strawberries, almond chocolate and the aroma of vanilla, cinnamon and lemon complete the feast. Prosper symbolizes the mediocrity of Smith Conundrum. He belongs to every fraternity [Messac exaggerated, one could join only one], dines at the student cafeteria, spends his nights at clubs and never misses a match of baseball, football or hockey. He goes to church but only to highly recommended sermons. Prosper Doughnut prefers social life to lectures. He is a "cheerleader," chief of the "rah-rah boys," who lead the crowds in chanting "Rah-Rah" at university football games. Messac did not invent the term: the captions under the portrait of a member of the Class of 1927 referred to him as a "Rah-Rah Boy."135 Puritanical McGill refused to allow women cheerleaders, the bare-legged goddesses adored on more progressive campuses. Some unruly Smith Conundrum students dress up as sauvages, taking for their symbol a hirsute man on horseback - a "Hun" [the word for Germans used in the First World War]. The students identifying themselves as Huns do this for fun without knowing anything of Germany. Messac's Rab-Rah-Boy chapter had been published in 1930; Messac left its "Huns" unchanged in the 1942 novel-possibly as a gibe at the German occupiers of France.

"Rah-Rah" (from "Hurrah") was the university cheer everywhere- at rallies and football games all over North America. It appears in all student newspapers and the writings of Leacock and others. Messac must have heard and detested this expression of muscular exuberance daily but as usual had his fun with it as a symbol of American culture. The Smith Conundrum yell was:

Smith! Smith! Smith! S-M-I-T-H!

\section{SMITH!}

C-O-N-N-, conn, conn, conn!-Conn, conn, conn, conn, conn, conn!

N-U-N! nun! nun! nun!

Rah! Rah! Rah! [many times]

D-R-U-M, Drum!-Drum, drum, drum!

Conundrum, Conundrum, Conundrum! $!^{136}$

The real McGill Yell resembled that of Smith Conundrum:

M-c-G-I-L-L. What's the matter with Old McGill? 


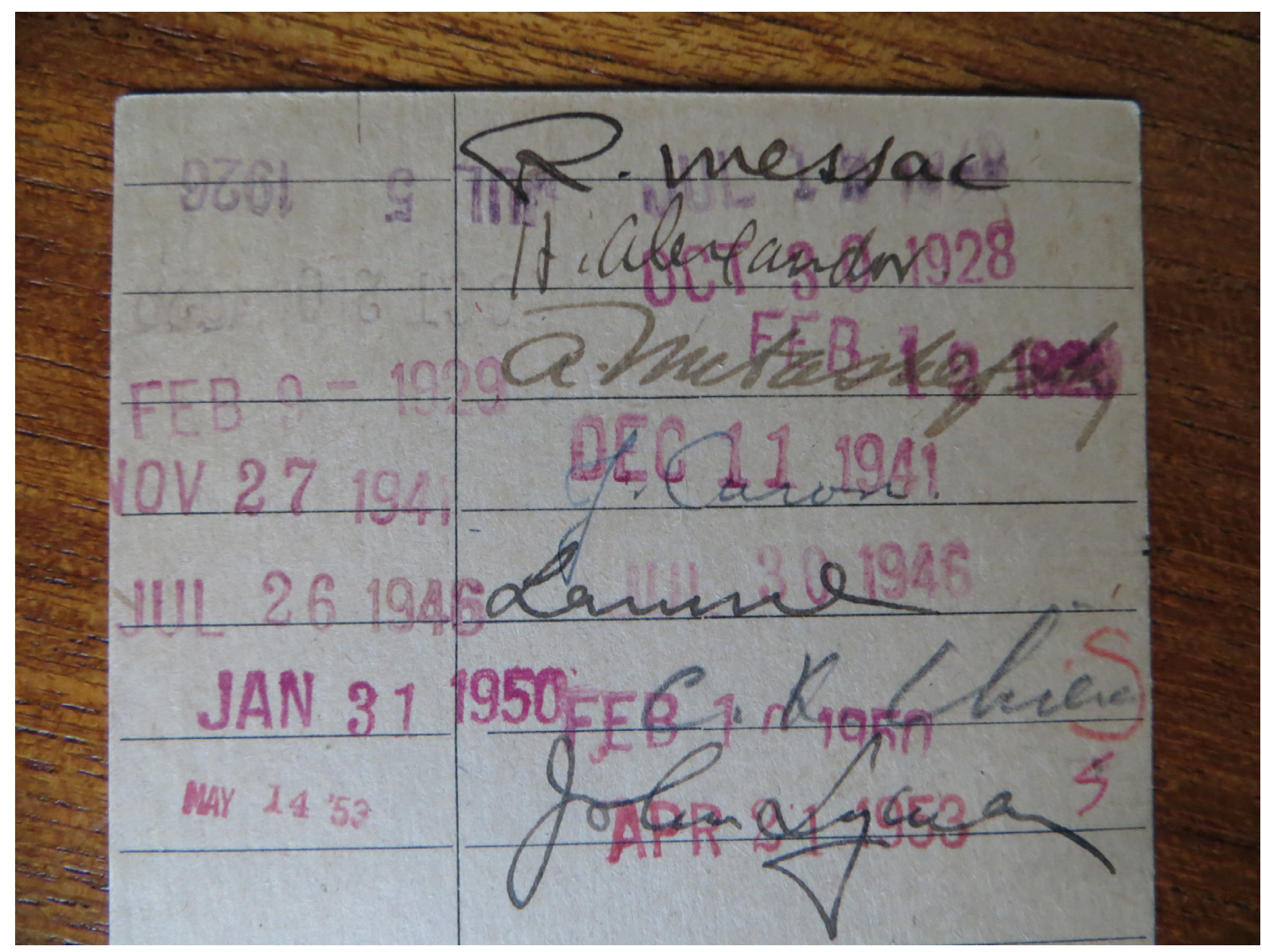

Figure 9. Les livres: Les Marana with Messac's signature, 5 July 1926

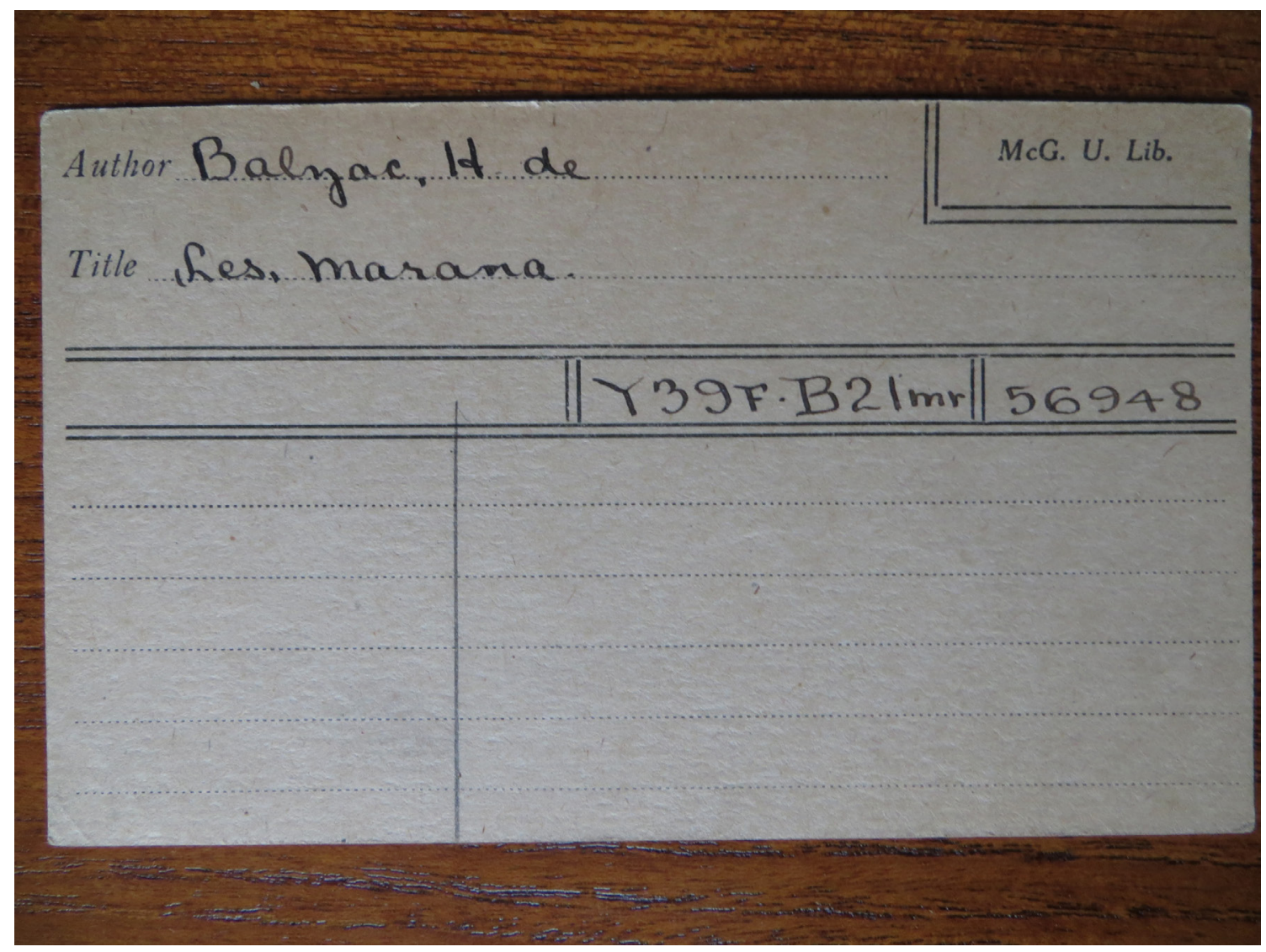

Figure 10. Les livres: borrower's card for Balzac 
She's all right, oh yes you bet!

McGill, McGill, McGill;

Rah, Rah, Rah! ${ }^{137}$

Prosper is distracted from his sundae by Ann Macdonell Pilgrim, the most beautiful of all co-eds. She wants a walk so he follows her to the campus. He adores her like a dog; he even walks her dog (Fig. 11). He ruins himself taking her to films, concerts, and buying her chocolates. The smell of acacias pervades the campus... Prosper's second year is nearly done... many students marry in their third year... Prosper blurts: I want you to marry me?... Say Ann, what d'ye think? Ann replies that she thinks she will marry Edgar Allan of the American Navy, a playful allusion to Edgar Allan Poe, who figured hugely in Messac's theses. She leaves Prosper alone. His two years at university weigh heavily and wasted. $\mathrm{He}$ stares mindlessly at his shoes which are the height of Chicago fashion [Chicago again!].

\section{Honoris Causa}

Starting here, the satire darkens and draws on actual McGill events rather than the more universal vignettes seen thus far. On 9 April 1926 McGill gave honorary LL.D. degrees to André

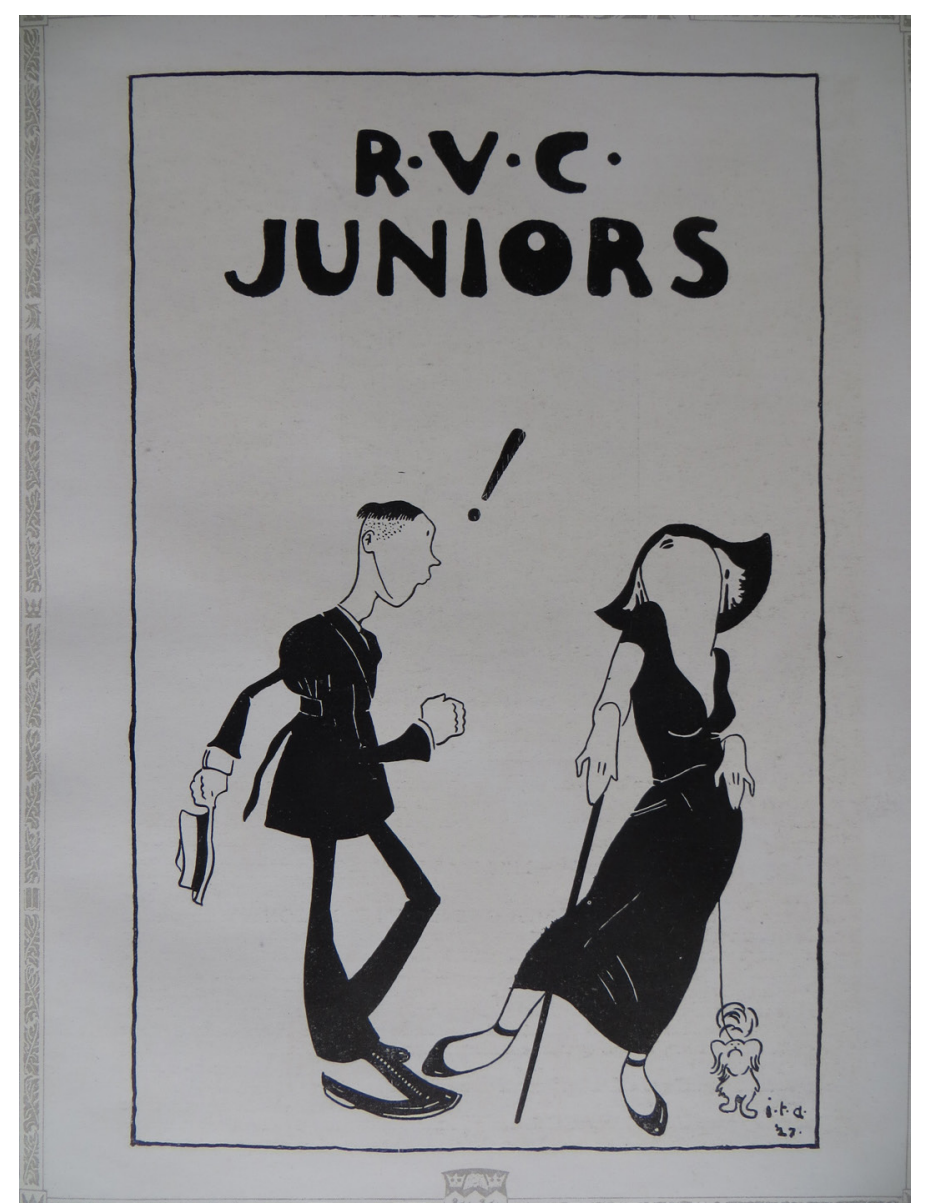

Figure 11. Le Rah-Rah-Boy: with Ann Pilgrim and her dog? Artist I.T. Archibald, B.Arch. 1928, Old McGill, 1927, 207
Honnorat (1868-1950) and the Duchess of Atholl (18741960), who were in Montreal attending an international conference on education (Fig. 12). Honnorat had founded the Cité Universitaire in Paris. Atholl was a Member of the British Parliament with education portfolios and was active in social reform. They were likely enough candidates for honorary degrees. Universities gained reflected glory by giving them; in a spectacular coup, McGill would award LL.D.s to Churchill and Roosevelt at the Quebec Conference in 1944. ${ }^{138}$ Not surprisingly, Messac deplored granting unearned degrees to anyone no matter how influential.

Addison, Lecturer in Greek, who besides Dubois and Eli Coil (seen later) seems Pluche's only intimate colleague, tells him the University will be giving honorary Doctor of Law (LL.D.) degrees to "l'honorable Honoré," a French senator and to an Englishwoman, "la vicomtesse Halloween." Addison smokes cigars and dreams of his Oxford past; he may have been inspired by a mixture of the Classics lecturer Paul McCullagh, just arrived at McGill in 1926 (graduate of Toronto not Oxford), who Messac knew through the Cercle Français, and the older, humorous, pipe-smoking William D. Woodhead, Professor of Classics, graduate of Oxford, Alberta and Chicago. Third and less likely may have been Oxonian Tommy Matthews (of Mathematics not Classics, who may have inspired Coil, seen later). ${ }^{139}$ Addison, Coil and the worldly Dubois are the ones who give the innocent Pluche the scoop on University machinations. Pluche is shocked that degrees are given unearned: "Honoris Causa! Vive l'Amérique! Plus d'examens, docteur en un seul jour!" The fictitious Honorable Honoré is a French Minister of Justice who had failed his law exams many times; Vicountess Halloween is being honored for her social work and research in women's prisons.

Pluche attends the special convocation with Addison in "Conundrum Hall;" the actual event took place in Royal Victoria College. [A.J. Roche and du Roure are listed in the Convocation records as attending. Messac is not listed; perhaps Roche told him about it.] Pluche is in rare good humour at the ridiculous "American" process of handing out unearned academic honours. "Nous allons honorer l'honorable Honoré," he alliterates. Colonel Artemus Dugout, the secretary of the Principal, General Rumblebass Balderdash, takes care of arrangements. $\mathrm{He}$ is based on Colonel Wilfrid Bovey, assistant to McGill's Principal, former General Sir Arthur Currie. [Bovey indeed was at the ceremony, directing protocol.] Now an immense building of a man makes his first appearance in the novel: General Balderdash himself. Pluche is told that the Balderdash was made a general because he looked the part; and since the Americans have no French Academy, after the war they made Balderdash a university principal. The dignitaries and professors march into the Hall. A newspaper account of the McGill event declared breathlessly: "The ceremony took place with full academic pageantry.... The gorgeous robes 

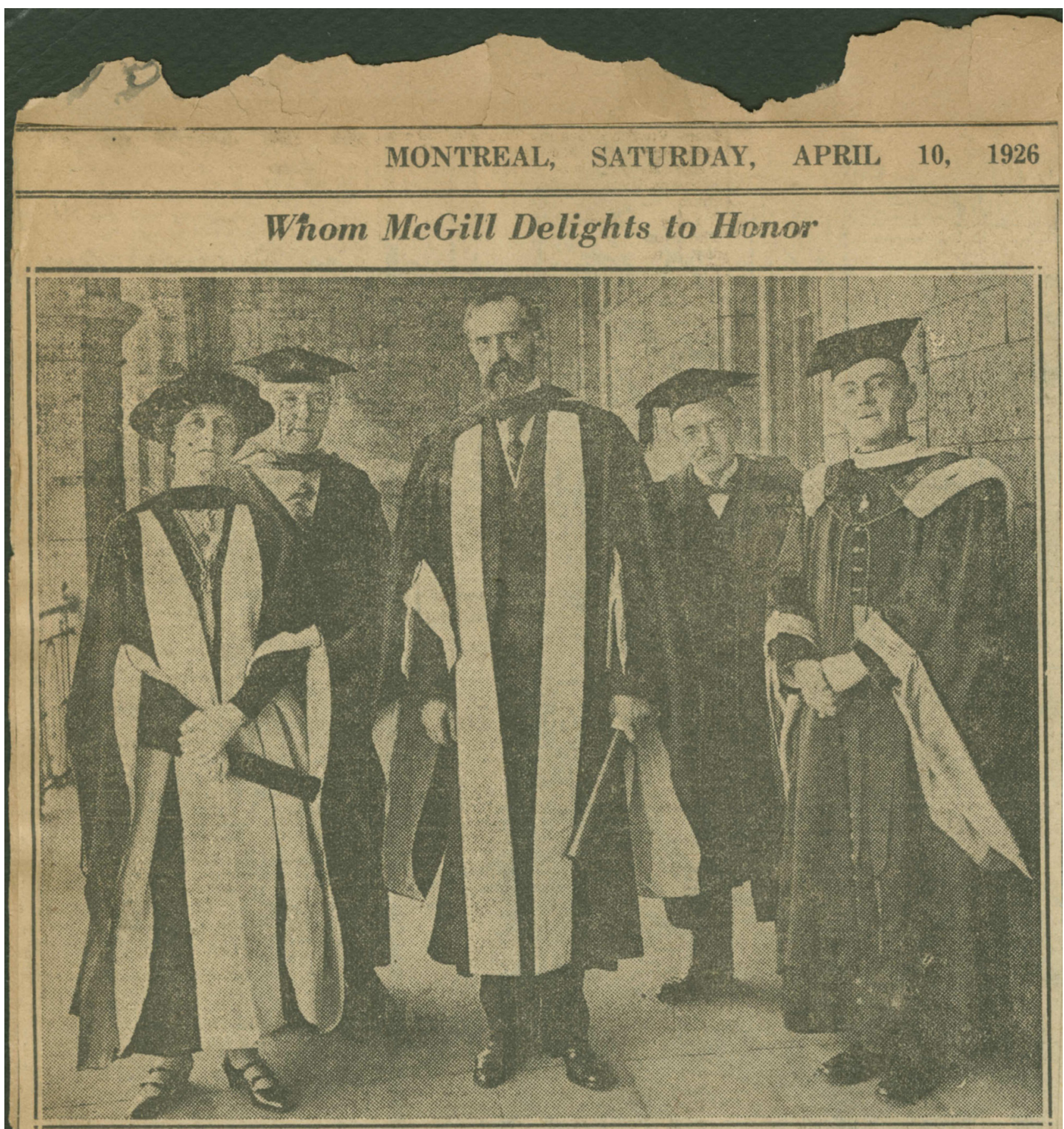

Left to right:-The Duchess of Atholl, M.P.; Miss Ethel Hurlbatt, warden of the Royal Victoria College; Senator Andre Honnorat, distinguished French legislator and founder of the Cite Universitaire, Paris; Prof. Rene du Roure, in charge of the French department at MeGil I University; and Canon Emile Chartier, vice-rector of th. University of Montreal, photographed after the special c onvocation of McGill University, held at noon yesterday, at which the Duchess and Senator Honnorat had conferr ed upon them the honorary degree of Doctor of Laws. Her Grace and Senator Honnorat are wearing the scarlet robes and hoods of the doctorate. They were presented for the honor by Miss Hurlbatt and Prof, du Roure respe etively. Sir Arthur Currie, as Principal and Vice Chancellor of MeGill University, conferred the degrees.

Figure 12. Honoris Causa: degrees for Atholl ["Halloween"] and Honnorat ["Honoré”], du Roure 4th from left, Montreal Star, 10 April 1926, MUA, McGill Scrapbook, Vol. 6 (1926), p. 130 
and hoods, signs of academic honors won from all the leading universities of the world, made a colorful setting...." ${ }^{140}$ Such trappings of academia made Messac - and Pluche - scoff.

Reverend Joshua Heluva, Dean of the College of Theology, invokes the blessing of the Lord of armies and professors. At the actual ceremony, it was Dean D.L. Ritchie of the Theological Colleges affiliated to McGill. Up front Pluche could see James Bunk, Dean of Graduate Studies, ochre skinned, face like a cubist portrait, luxurient white hair; he was completement gaga. As satirists simplify, usually unflatteringly, so Messac focused on the age of the real Dean, Robert Ruttan, who had taught Chemistry since 1886, had luxuriant white hair and was nearly $70 .{ }^{141}$ Balderdash confers the degrees. He speaks in a strange, garbled tongue. He is speaking Latin, whispers Addison. Strange, I learned Latin, says Pluche. Balderdash knows no Latin; he has memorized the formula: Ego admitto te ad gradum and so on. [Currie may not have known Latin but he made a good recovery once, when he gave some American scholar an honorary degree. The recipient replied with a short speech in Latin; Currie "rose splendidly to the occasion, stood to his full height... and said: "Pax vobiscum."142] In the Atholl/Honnorat ceremony, the head of Royal Victoria College, Ethel Hurlbatt gave the laudatory introduction for the Duchess, unparodied in the fictional account. ${ }^{143}$ But des Boys pompously praises Honoré in French; in real life du Roure honored Honnorat, also in French. Balderdash and Honoré babble uncomprehendingly at each other in English and French. The fictional Dean of Law, Jenkins W. Cattle, puts the scarlet robes on the recipients; the McGill Dean of Law, R.A.E. Greenshields, did the same for Atholl and Honnorat. The fictional account has "la Marsaillaise" and "God Save the King" sung; the real event had "Hail! Alma Mater!" and "God Save the King." Pluche tells Addison that they have watched ignoramuses honor one another. Addison replies "en Amérique, c'est ce que nous appelons a learned manifestation." 'This lone chapter was given an amusing translation by Gladys Quirk in $1975 .{ }^{144}$ To top things off, less than a month later McGill held yet another special convocation - to give an honorary LL.D. to Sir Esmé Howard, British Ambassador to the United States, who was in Montreal to address the Canadian Club on disarmament! $!^{145}$ But Messac already had more than enough ammunition from the Atholl/ Honnorat degrees...

McGill's reality and Messac's fiction and journalism in Le Progrès civique all intersect here. The honorary degree event had everything Messac hated: sycophancy, opportunism, debasement of academic degrees, and academic ceremonial. It inspired Messac's most bitter attack on "American" academia, particularly the market in honorary degrees. It was published a mere five weeks after the event, in Le Progrès civique (15 May 1926) in an article titled by that favorite American word "Bunk" [the name he also gave the Graduate Studies Dean]. He ridicules American susceptibity to charletans such as psychoanalysts. Any American institution could - and often did-call itself a college or university. ${ }^{146}$ America boasted it had the most university graduates but look at what they studied! He mocks Americans for elevating technical subjects to university programs. The University of Illinois had a magisterial chair in "swine husbandry." Chairs in crossword puzzles would be next. Messac cited Cornell with its Hotel School; Stephen Leacock would humorously predict in 1931 that one of the absurdities in McGill's future would be the installation in 1965 of "the first (Full) Professor of Hotel Keeping." ${ }^{147}$ Worst of all was the American practice of granting degrees honoris causa, for anything from giving a good sermon to giving money. Do you want to be a Doctor of Philosophy? Don't bother writing a thesis - get an honorary degree! He saved special bile for bible colleges, claiming the poorer religious universities sold honours for $\$ 50$. Such "Bunk" is just a form of lying-yet in time America doubtless will grow out of charlatanism. Europe too has its faults, he adds. The young culture serves as a model for the older, returning it to primitivism. The horror of the modern world is that men of merit must convince and fool others. ${ }^{148}$ In addition to his McGill experiences (what a store of criticism he built up there!), Messac may have been influenced by two furious critiques of American universities being ruled by monied interests, snobbery, and sports: Thorstein Veblen's The Higher Learning in America (1918) and Upton Sinclair's The Goose-step (1923).

\section{L'Académicien I, II, II, IV, V}

\section{I}

These five chapters are held together by the leitmotif of a new French professor, "1'Académicien," who lets people think he is a member of the French Academy when he is really "Officier d'Académie" - an honour given by the French government for services to education but which does not confer membership in the prestigious French Academy. However the Americans do not realize this! [In real life, Professors Villard and William Caldwell (Cadwallader Talkinghorse?) were officiers d'Académie - perhaps inspiring Messac's focus on this pretentious ambiguous title.] The chapters also send up McGill's prestigious, profitable French Summer School, held in July, directed by du Roure, in which Messac taught in 1925, 1926, and 1927. ${ }^{149}$ The "villain" of these chapters, L'Académicien, Léon de Ribassier de Pivres (hereafter Ribassier) gets a position at Smith Conundrum's "cours d' été" directed by des Boys. Messac may have taken the name "Ribassier de Pivres" from Mlle. Riballier des Isles, instructor in the Summer School in 1926 and 1927. When the chapters were published serially in Le Progrès civique in 1931, the brief editorial note promised readers that they would be astonished and surprized by this "amiable fantaisie qui permit de faire accepter les vérités les plus invraisemblables." ${ }^{150}$ 
Smith Conundrum gives its summer sessions in imitation of University of Chicago-Messac assigning yet another Chicago influence [the most important was on McGill's new Sociology Department]. ${ }^{151}$ In the novel the French Summer School is held in the Presbyterian College; in reality it was held there in 1925 while in 1926 and 1927 it mainly used the women's Royal Victoria College. As will be seen, the professor who inspired the Académicien was at McGill in Fall 1926 but Messac also mixes in real events of 1925 and 1927. Most of the French Department staff taught in the Summer School. The School gave beginner, intermediate, and advanced courses in the mornings with cultural activities in the afternoons; it was successful, made a profit and had an international reputation. In 1926, a typical year, the School ran from 28 June to 31 July, had 22 instructors, including the whole French Department and outsiders like poet Marie Le Franc, who left a brief description of the School's activities in a story. ${ }^{152}$ The summer staff included French Canadians, the Department dropping its prejudices for practical reasons, and Messac would have known the Quebecoise suffragette Idola Saint-Jean; she taught advanced diction, Quebec accent or not! There were 171 students ( 29 men, 142 women). The oldest was 60, the youngest 16; 116 came from the United States, 55 from Canada. Many students were teachers of French, a few working towards an M.A. Students pledged to speak French at all times, lived in residence, and ate together. ${ }^{153}$

The fictional, odd looking Ribassier, who changes his appearance at times, had arrived in Montreal with a French theatre company which got stranded. The women found work at the "Gayety," showing their thighs, with the prospect of earning 50 or 60 dollars a night en travaux supplémentaires. There was a real Gayety Theatre in Montreal, renowned for strip-tease acts. ${ }^{154}$ The men, like Ribassier, whose chief accomplishment is as a theatre prompter, must try to find jobs teaching French. Pluche thinks: the Gaiety for the women, teaching for the men: Chacun son genre de prostitution.

\section{II}

The summer students rehearse an abridged production of le Bourgeois Gentilhomme, a collaboration between Molière and "Mrs Gelb," a longtime teacher in the French Summer School and the French Department. She is modeled on Assistant Professor Lucie Touren Furness with whom Messac had cotaught courses in the regular session. Alice Sharples, who took French in the 1920s (B.A. 1923, M.A. 1925) recalled how important dramatics were for the French Department and how the bachelor du Roure and Touren Furness often acted together in local productions, such as those in the new Moyse Hall in the Arts Building, taking the parts of husband and wife in popular plays: "As in all French plays, either the husband or wife was unfaithful, or maybe it was both."155 Touren Furness married late in life but soon had two babies, in
1926 and ca. 1927. In the novel, Messac mischievously inflicts surprize pregnancy on the fortyish Mrs. Gelb. Molière might not have recognized Gelb's version of his play, which featured sensational dances by student Pixie Pickering: "Elle dansa avec tant d'ardeur que ses cuisses claquaient l'une contre l'autre...." The McGill Summer School actually performed le Bourgeois gentilhomme in 1927, with a dancer, to enthusiastic reviews. ${ }^{156}$

\section{III}

Des Boys asks Pluche to give a summer course on Balzac. Pluche declines, pleading his thesis. In reality, Messac gave a course devoted to Balzac but during the regular academic sessions in 1926-27 and 1927-28. The opportunistic Ribassier volunteers to give the course on Balzac. [No such course was given in the real Summer School.] Pluche hears Ribassier lecture on Balzac and ridicules his vocal mannerisms and lack of knowledge. But the students admire Ribassier and repectfully call him "L'Académicien." He is so profound, says Eleanor Whale, a blonde of 28 who looks 17 because she wears no makeup. The dancer Pixie Pickering avidly pursues him. She teaches him archery and pulls on his tie like a leash telling him "You are my pet dog!" Rich Eleanor and richer Pixie compete for Ribassier. Pluche fails to convince Pixie that Ribassier is not a member of the French Academy. Ironically she thinks Pluche is jealous that Ribassier is giving the course on Balzac.When she asks Pluche if Ribassier realizes she is richer than Eleanor, Pluche plots mischief: Count on me. I'll tell him.

\section{IV}

Summer School ends and prizes (as at McGill) are distributed by French officials while the Marseillaise plays-clues that we are not in a typical American university. In Messac's time, the French consul, Vitrolles, and representatives of the Alliance Française gave awards to the best students. Eminent speakers came to the ceremonies: Athanase David in 1926. $\mathrm{Du}$ Roure worked with Athanese David on legislation to encourage literary and scientific work in Quebec. Du Roure also had been appointed with Currie's support by the French government to be Délégué Universitaire to the French consulate in Montreal. ${ }^{157} \mathrm{Du}$ Roure and Villard had prestigious ties with the French consulate and the Alliance Française-more fuel for Messac's satire. Fall term arrives. Mrs. Gelb will soon have her child and must be replaced. [In real life Touren Furness married in 1924; with du Roure's support, she persuaded Principal Currie to keep her on as McGill's first married woman professor. ${ }^{158}$ ] Won't Mrs. Gelb be replaced? asks Pluche. No, Smith Conundrum is humanitarian; it will keep her on, says Dubois - we will all have to share the extra teaching. What about my thesis, cries Pluche; we must replace her! What is Ribassier doing now? He was alright for the Summer School, replies Dubois but he 
won't do for the regular sessions. He is no worse than Mrs. Gelb and her play, retorts Pluche. So Ribassier gets hired for the regular session. He had fraudulently convinced Principal (and former General) Balderdash that he had known General Joffre during the war. Now he is under Balderdash's protection. By now everyone calls Ribassier le marquis in addition to officier de l'Académie française. He teaches medieval literature and makes a great hit with the students although he is incompetent. He has even gotten himself promoted to Associate Professor, a rank Dubois has failed to get for years!

\section{V}

Pixie Pickering returns to pursue Ribassier. She and Eleanor Whale argue over what kind of ribbon decoration Ribassier is entitled to wear as an Académicien (a subject guaranteed to raise Pluche/Messac's bile). Pluche matchmakes, telling Ribassier how rich Pixie is. Christmas vacation comes, Pluche is locked up with Zschokke. When the new term starts in January, Ribassier has disappeared. So has Pixie. Des Boys opens a letter from him: "Unforseen family business has forced me to leave suddenly." When you read this I will be on the Atlantic. Next a telegram arrives from an ocean liner. Ribassier and Pixie have married on board. Pluche observes that Ribassier has struck it rich. Des Boys declares, we will all have to take over his courses. Has Pluche's playful abetting of Ribassier's romance backfired? Everyone protests. Except Dubois. He will do the extra teaching... in return for promotion to Associate Professor! [Perhaps Messac had heard that it had taken Villard a long time before being promoted to Associate in 1924.] Pluche smiles, shrugs and goes away.

Messac's French Summer School experience closely resembled Pluche's. In July 1927 Messac lectured on Anatole France to his largely American female class, having just published "Anatole France vu par les américaines" in Le Progrès civique in April 1927-as usual his research fueled both his teaching and publishing. In his three summers at the School $(1925,1926,1927)$, Messac also taught the contemporary French novel, history of France 1815 to present, and literary criticism. As seen, he drew on Touren Furness, Villard and du Roure for the novel's Summer School episodes. Ribassier is Messac's most prominent character after Pluche, des Boys and Dubois. While the latter three resemble their inspirations, it is impossible to say if Ribassier, "l'Académicien," is even a remotely accurate portrait of either man suggested below as his original-feckless and on the make, he even may be a composite of everyone Pluche/ Messac mistrusted at University.

For his character Ribassier, Messac borrowed from the circumstances surrounding the brief career of Laurence Adolphus Bisson (1897-1965) in the McGill French Department in Fall 1926. As with du Roure and Villard, one assumes Messac changed, simplified and "improved" Bisson for satirical purposes. Bisson did not teach in the Summer School nor as far as is known was he an officier d'Académie. In the novel, Ribassier is under the Principal's protection. In real life, Bisson had good references; Principal Currie interviewed him and appears to have hired him in April 1926 as Assistant Professor for one year. ${ }^{159}$ At this period, the Principal often was involved in choosing and hiring academic staff, usually in consultation with Heads or Deans. While Ribassier filled the vacancy left by Mrs. Gelb, in real life Bisson replaced Messac's colleague André Roche, who went on to a distinguished career at St. Francis Xavier University. Born on Jersey, bilingual with a French mother, educated at Pembroke College, Oxford, Bisson was working toward a Ph.D. at the Sorbonne (which apparently created no bond with Messac) and taught at University of Toronto before McGill. In Messac's rendering, the similarities between Ribassier and Bisson are numerous if circumstantial. Ribassier offers to teach medieval literature-Bisson would later publish a text which included medieval literature (1943). Ribassier courts his students' favour-Bisson told the Daily he preferred McGill students over his former ones at Toronto as they were better prepared in French. ${ }^{160}$ Bisson had worked for the League of Nations - a source of prestige like Ribassier's officier d'Académie title. To complete his League work, Currie allowed Bisson to report slightly late [by 5 October ] in $1926 .{ }^{161}$ Currie had also agreed with du Roure that Messac too could return at the very end of October 1926, so French was briefly shorthanded - this may have caused friction. It may be speculated that Bisson gave a few weeks of Messac's honours course on Balzac that October until Messac returned. If so, this may account for Pluche's contempt for Ribassier's teaching of Balzac. Moreover, Bisson became ill in November 1926 and du Roure, while sympathetic, pointed out it to the Dean that it was impossible for him, aided by Messac and Touren Furness to fully cover his courses. ${ }^{162}$ Both Ribassier and Bisson quit without notice at Christmas (Bisson probably due to illness). Currie had to tell the Board of Governors Finance Committee that Bisson had left without giving any reason and that a replacement had been engaged. ${ }^{163}$ As with Ribassier in the novel, Messac and the others could not add Bisson's classes to their own workload so a replacement, Louis d'Hauteserve, had to be found quickly. Messac spun all this into the tale of Ribassier's elopement to Paris with Pixie Pickering. Whatever caused Bisson to leave, he ended up in England where he was a solid scholar. ${ }^{164}$

Ribassier had taught at the Summer School previous to his Fall term. Bisson had not. In the novel Ribassier is promoted to Associate; in real life Bisson remained an Assistant like Messac, while Villard, unlike Dubois, already had been promoted to Associate. As a final wrinkle on Messac's possible inspirations for l'Académicien and one which involved the summer school, Edouard Sonet (1880-1971) may be cited. Born in France, Sonet taught French at University of Alberta from 1911 to 1947 . He was highly recommended to Principal 
Currie to teach in the 1927 McGill French Summer School. Sonet (like Messac) was attracted by McGill's well stocked Library. Currie passed the recommendation to du Roure who replied that the 1927 staff was already complete but a position might become available for Summer 1928. Currie reported to Alberta that Sonet was on the list for 1928. But in June $1928 \mathrm{du}$ Roure wrote Currie that his recollection of their "conversation" was that he would take Sonet only if a vacancy came up and that he had notified Sonet in December 1927 there was still no vacancy:

It is true that later on after my letter, Professor Messac told me that owing to his research work, he must spend the summer in France. I did not offer this vacancy to Professor Sonet, because of a complication that I would rather explain to you verbally. ${ }^{165}$

It is unclear what the "complication" was and whether it involved Messac. At any rate, Messac may have been thinking of Sonet as well as of Bisson in this complicated chapter. What seems certain is that Currie had again, as in the case of Bisson, sponsored a candidate to the French Department and du Roure and Messac may have resented it.

\section{La Bataille de Tipperary}

Here Messac targets Principal Currie, the inspiration for Principal Rumblebass Balderdash. ${ }^{166}$ Messac's distrust of Currie was inevitable, since Currie personified McGill when Messac taught there. Currie was the war hero leader of Canadian troops; Messac was anti-war. Currie and Balderdash represented hierarchical authority, had no academic qualifications and were admired by what Messac and Pluche considered to be a toadying staff. Currie opposed socialist views among staff and students, although he tended to be cleverly flexible in dealing with political opposition and critical student publications like the McGill Fortnightly Review. Currie and Lord Byng of Vimy, Governor General of Canada, 1921-1926 ("Lord Pyff of Tipperary" in this chapter) had won the Canadian victory of Vimy Ridge (April 1917); Currie would later be criticized for losing lives taking Mons at the war's end, 10-11 November 1918 (Fig. 13). Messac expanded these two engagements into the fictive battle of Tipperary, Balderdash commanding, in which 15,000 Americans died for the sake of glory on the last day of the war. In 1927 an Ontario newspaper claimed Currie had wasted lives taking Mons on the last day. Currie sued for libel and in April 1928, as the school year ended, Messac followed the libel trial along with the rest of McGill.

The professors drift in and out of the Arts Building's common room discussing the case. Pluche chats with Eli Coil, a young newly hired mathematics instructor (inspired perhaps by Tommy Matthews, born in 1891, hired in 1920, of Mathematics or the young Paul McCullagh, born in 1903, hired in 1926, of Classics not Mathematics ). ${ }^{167}$ Coil tells Pluche about Balderdash's undistinguished pre-war career and how he wasted 15,000 lives the final day. What do the French do with generals after the war? asks Coil. We make them members of the Academy. We don't have that in America, says Coil, so we made Balderdash a university principal-the same observation occurs in Honoris Causa. At the moment, the trial is going against Balderdash. In cinematic style, bulletins come in by telephone. A professor in his sixties arrives: Julius Werther, in Pluche's eyes, one of Smith Conundrum's rare scholars. He has helped Pluche with his thesis. In real life, this was Hermann Walter, head of German, who lent Messac books for his thesis. ${ }^{168}$ Currie had suspended Walter during his dispute with J.L. Morin mentioned above, another reason for Messac to dislike Currie. Some professors congratulate Werther; soon his old enemy Balderdash may be ousted if he loses his case. Now it is Addison who tells Pluche Werther's story: Werther was openly atheist; a Protestant clergyman [Morin indeed was a Protestant cleric] had poisoned his well. After three years of

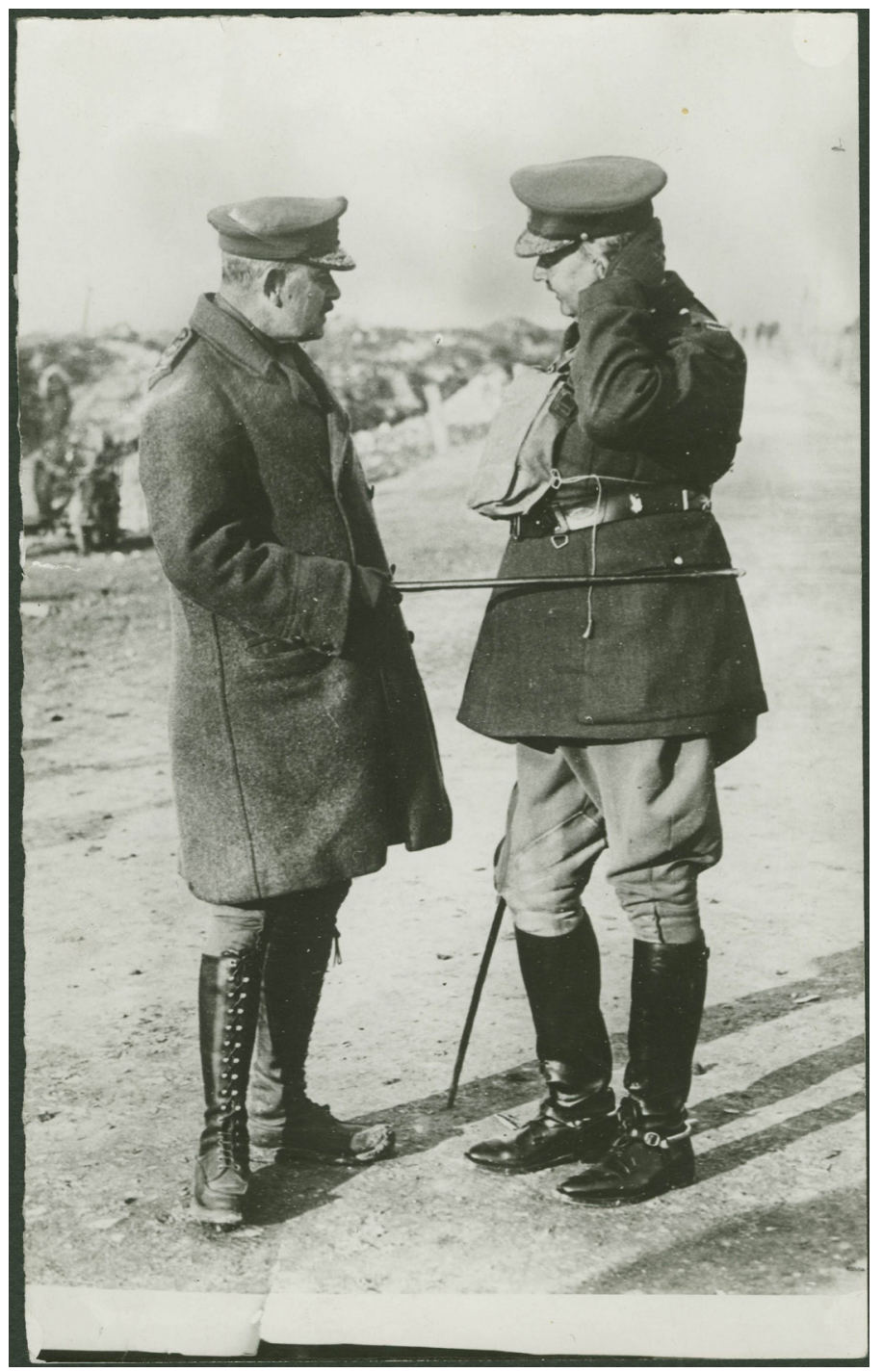

Figure 13. Tipperary: Sir Julian Byng ["Pyff"] (L) and Sir Arthur Currie ["Balderdash"] at Vimy Ridge, 1917, photographer unknown, MUA 00000481.04 .316 
litigation, the court blamed Werther not the poisoner [in real life, no guilt was proven although the aged Morin soon had to resign]. Why? asks Pluche. Replies Addison: we AngloSaxons always condemn the victim. Why? To spare the feelings of the criminal, who is already suffering from guilt. Balderdash, a fervent Protestant, had tried to fire Werther but failed [in real life Currie had suspended first Morin then Walter as the court decisions went back and forth; Walter emerged victorious as head of German, du Roure fortuitously as head of French].

As the news of the trial shifts, Dubois goes back and forth among the groups of professors. They are all sniffing the air. Will Balderdash win or lose and possibly be deposed as Principal? Pluche says it is like a play. Finally Balderdash wins but is awarded only a 1/100,000 of what he demanded in damages [in reality Currie won 1/100 of what he asked: $\$ 500$. against $\$ 50,000$ ]. Still, Balderdash [like Currie] was vindicated. Colonel Artemis Dugout [based on Wilfrid Bovey], Balderdash's right hand, appears. Led by Dubois, the professors rush to Dugout to subscribe to a victory dinner for the triumphant Principal. The General has won again, muses Pluche. Addison whistles "It's a long, long way to Tipperary." When Currie returned from the trial to McGill on 2 May 1928, bands played and a cheerleader-Prosper
Doughnut? - led the students in the McGill yell: Rah-RahRah! Most McGill professors and students admired Currie. Messac stayed in touch with Walter, perhaps the only McGill professor he admired, writing him a congratulatory letter on Walter's biography of Heine in $1931{ }^{169}$

\section{On rentre}

This is Pluche/Messac's testament, the sad yet liberating chapter, in which Pluche decides to leave Smith Conundrum. Pluche begins his fourth year. It is October, the only time when the campus is beautiful. The leaves turn colour, the trees mask the ugly buildings [the buildings were admired by most McGill staff, including Leacock ${ }^{170}$ ], the students greet Pluche and one another, coeds wear new outfits, professors old gowns.... But Pluche, melancholy, wanders the campus. The Arts Building janitor, red faced, deferential, asks him him if he enjoyed his holidays and gives Addison a parcel. Pluche asks Addison if he has noticed how important university janitors are; they render services, know everything, and are more indispensable than the Dean. [The Arts Building janitor, Bill Gentleman was beloved by all, as was janitor-poet Harry Barker, and others.] Addison declares that the janitors are the only people with whom the professors can feel important.

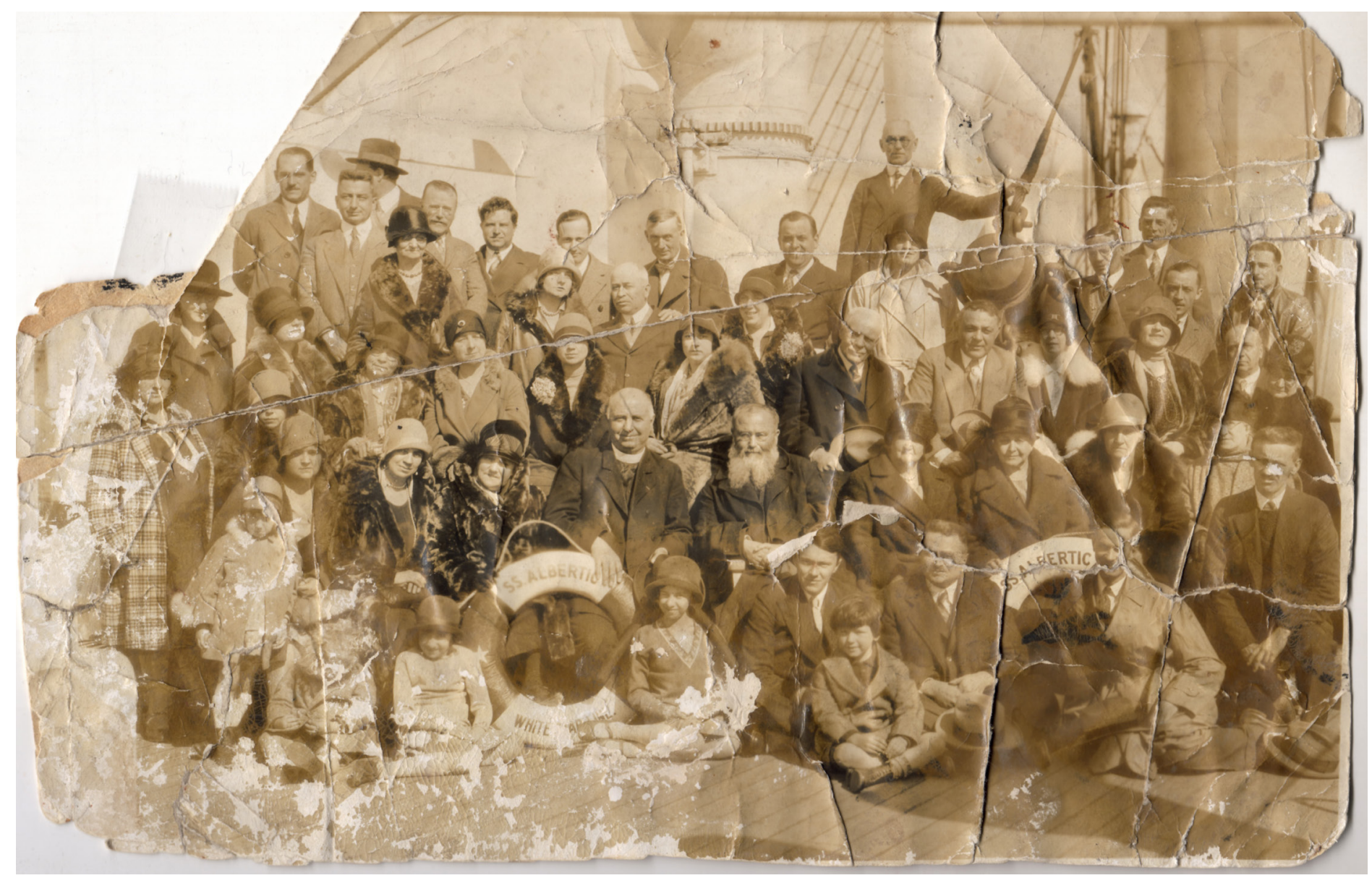

Figure 14. On rentre: Messacs returning to Montreal for last time, Sept. 1928, on S.S. Albertic. Germaine and Ralph, front, extreme left, Serge seated foreground, Régis, last row, 5th from left. Photograph: Canadian National Railway, courtesy O. Messac, Paris 
The students are younger, richer and socially superior while the Principal, Deans and wealthy Governors can fire them at will. Addison muses : we professors are " $a$ kind of higher club servants... subject to dismissal just like servants."

Pluche gives his lecture in a trance. He walks on campus again, passing billboards announcing lectures. Gladys P. Winegar of the University of Nebraska, "Ph.D. in Euthenics," will be lecturing on "The bacterial contents of Undershirts." Here is another example of Messac using real life quite literally-a researcher, Gladys Winegar, from University of Nebraska, did indeed write, A Study of the Bacterial Content of Cotton Undershirts (Kansas State Agricultural College, 1927, 106 pages)!171 This epitomized the lowly subjects of "American" university scholarship for both Pluche and Messac. Another poster invokes the bête noire of religion: a sermon by Nathanielson Clothesline on "The several roads to hell." Next the military: Pluche sees a recruiting poster for reserve officer training by "Colonel Martlet," in real life Colonel Stuart Forbes, war hero and Director of Athletics and cadets. The martlet is McGill's symbol-a bird without legs. Messac may have known that Forbes loved sketching this bird for heraldic decorations. Pluche mutters to himself that Winegar and Clothesline are charletans, then asks how he differs from them. People want their learning more than his. Who cares about French literature? It is only on the curriculum out of tradition, of no use to future businessmen. Cadwallader Talkinghorse appears. Muses Pluche: that's whom everyone admires; the students quote him in the Daily ${ }^{172}$ but he cowtowed like the others during the "Tipperary" trial.

Recalling Addison's remark, Pluche realizes he is indeed just a servant. The powers that be support the Ribassiers and the Talkinghorses not him. Money rules in America. Here the novel echoes Messac's articles in Le Progrès civique. Promotions and raises go to adventurers like Ribassier and the time-serving Dubois. Pluche recalls his recent request to des Boys for an increase. Wait a bit, he was told. The University is planning a campaign - the bankers will give $\$ 10$ million, but times are hard at the moment. ${ }^{173}$ [McGill's planned funding campaign was cancelled by the Depression of 1929 . Ironically, Du Roure managed to get small increases for staff soon after Messac left. ${ }^{174}$ ] Pluche realizes the University is a luxury, supported only when the bankers have surpluses. He has gone in a circle; he is back at the Arts Building and the founder's urn. He walks quickly, firmly to his apartment and writes a polite letter to the Board of Governors stating that he will not have the honour of being on staff the next academic session. ${ }^{175}$
Another Frenchman abroad whom Messacmayhaveknown from University of Glasgow, Michel Poirier, taught French at University of Toronto. In May 1928 he commiserated with Messac. He too was frustrated by low pay and superiors he found incompetent. He was sorry to hear Messac's health was suffering and that his teaching and research were exhausting him. ${ }^{176}$ The Messacs visited France for final research in the summer of 1928, sailing back that Fall (Fig. 14). By then Messac like Pluche may have decided to leave McGill after this, his final year. We may assume that like Pluche he was disatisfied with his pay, the academic hierarchy and poor academic standards, although his relations with colleagues appear to have been unruffled and his criticisms internalized in the novel he was starting. By 24 January 1929 Messac had resigned. The tragic death of the Messac's newborn, third son Francis, who lived from 4 February to 28 February 1929, was not the cause of their leaving as has been supposed. ${ }^{177}$ He had his thesis to present to the Sorbonne and a career in France ahead. He requested re-integration into the French university system and taught at lycées but never held another university position, probably because of his leftist, contrarian views. He continued to write furiously on everything from marriage to war-always from a secular, anti-religious, antitraditionalist, anti-bourgeois, anti-militarist, non-violent, non-nationalist viewpoint. The Gestapo arrested him in May 1943 for helping the Resistance (non-violently) and he was afterwards taken away Nacht und Nebel and died in Germany early in $1945 .{ }^{178}$

Messac took Harry Swellhead, Goldye Belemnith, Talkinghorse, Dubois, des Boys and Balderdash back to France for his novel. At McGill, he left the traces we have seen in the archives and publications. This witty young teacher must also have left a feeling of loss in some of his colleagues and students. His five years in America seem neither long nor short. Reporting on the French Department in 1929, Dean of Arts Ira MacKay found it just passable and recommended that the head [du Roure] should be replaced by someone who would be more "socially intimate with his staff" and would keep them at McGill-perhaps referring to the loss of Roche, Bisson, and most recently Messac. But du Roure [and des Boys] led charmed lives and endured, as Messac [and Pluche] affectionately realized they would. "I deeply regret the loss of Professor Regis Messac," continued the Dean. "He is a fine scholar, but I fear that his place is in a University in his own country." ${ }^{179}$ This was Messac's epitaph at McGill. He never joined the circle of contented, aging professors sipping whisky in the Faculty Club bar. But McGill provoked him; he brewed his ideas there. Later he would face a world far worse than "An American University." 


\section{Appendix: Cast of Characters of Smith Conundrum with McGill Inspirations}

\section{Smith Conundrum University $\quad$ McGill University}

\begin{tabular}{|c|c|}
\hline In alphabetical order by last name: & Definitely inspired by, with some real life similarities: \\
\hline Balderdash, Rumblebass. Principal & Principal Sir Arthur Currie (1875-1933) \\
\hline Chicago Professor ("un professeur de Chicago") & Stephen Leacock (1869-1944). Economics \& Political Science \\
\hline $\begin{array}{l}\text { des Boys de la Tour, Vicomte. Chef, Dépt. Français } \mathcal{E} \text { cours } \\
\text { d'été }\end{array}$ & $\begin{array}{l}\text { René du Roure (1881-1940). Chairman, French Dept. \& } \\
\text { French Summer School }\end{array}$ \\
\hline Dubois, Père. Dépt. Français E cours d'été & Prof. Paul Villard (1867-1952). French Dept. \\
\hline Dugout, Colonel Artemus. Secrétaire du Principal & Colonel Wilfrid Bovey (1883-1956). Assistant to Principal \\
\hline Gelb, Mrs. Dépt. Français E cours d'été & $\begin{array}{l}\text { Mrs. Lucie Touren Furness (1887-1974). French Dept. \& } \\
\text { French Summer School }\end{array}$ \\
\hline Godwin, Dr. Librarian & Dr. Gerhard Lomer (1882-1970). University Librarian \\
\hline Halloween, Vicomtesse & Duchess of Atholl (1874-1960). M.P. (United Kingdom) \\
\hline Honoré, l' Honorable & André Honnorat (1868-1950). French Senator \\
\hline $\begin{array}{l}\text { Pluche, Prof. André J. (Protagonist). Dépt. Français E cours } \\
\text { d'été }\end{array}$ & $\begin{array}{l}\text { Prof. Régis Messac (1893-1945). French Dept. \& French } \\
\text { Summer School }\end{array}$ \\
\hline Pyff, Lord & Lord Byng of Vimy (1862-1935) \\
\hline Ribassier de Pivres, Léon de. Dépt. Français \& cours d'été & $\begin{array}{l}\text { Prof. Laurence A. Bisson (1897-1965). French Dept. possibly } \\
\text { with elements of Edouard Sonet (1880-1971), French Dept., } \\
\text { Univ. of Alberta }\end{array}$ \\
\hline Smith Conundrum. Fondateur, Smith Conundrum University & James McGill (1744-1813). Founder of McGill University \\
\hline Snuffbox, Alexander. Dépt. Histoire & William T. Waugh (1884-1932). History Dept. \\
\hline Werther, Julius. [Unnamed dept.] & Prof. Hermann Walter (1863-1952). German Dept. \\
\hline
\end{tabular}




\begin{tabular}{|c|c|}
\hline & Possibly inspired by: \\
\hline Addison. Dépt. Classics & $\begin{array}{l}\text { ? Mixture of Paul McCullagh (1903-1999), and William D. } \\
\text { Woodhead (1885-1957), both of. Classics Dept., and Tommy } \\
\text { Matthews, (1891-196?). Mathematics Dept., later Registrar }\end{array}$ \\
\hline Coil, Eli, Dépt. Mathematics & $\begin{array}{l}\text { ? Mixture of Tommy Matthews (1891-196?). Mathematics } \\
\text { Dept., later Registrar, and Paul McCullagh (1903-1999), Classics }\end{array}$ \\
\hline \multirow[t]{2}{*}{$\begin{array}{l}\text { Talkinghorse, Cadwallader H. Parsley Prof. of Ethics and } \\
\text { Moral Philosophy }\end{array}$} & $\begin{array}{l}\text { ? Dr. William Caldwell (1863-1942). Macdonald Professor of } \\
\text { Moral Philosophy }\end{array}$ \\
\hline & Positions match, little other detail: \\
\hline Bunk, James J. Doyen de la Faculté de Graduate Studies & Robert Ruttan (1856-1930). Dean, Graduate Faculty \\
\hline Cattle, Jenkins W. Doyen de la Faculté de Droit & R.A.E. Greenshields (1861-1942). Dean, Law Faculty \\
\hline Heluva, Joshua. Doyen du Collège de Théologie & $\begin{array}{l}\text { David L. Ritchie (1864-ca.1960). Dean, Theological Colleges } \\
\text { affiliated to McGill }\end{array}$ \\
\hline Martlet, Colonel. Directeur, Compagnie-école de cadets & $\begin{array}{l}\text { Colonel Stuart Forbes (1889-1965). Director of Athletics \& } \\
\text { Canadian Reserve Officer Training }\end{array}$ \\
\hline $\begin{array}{l}\text { Quartier de Montrouge, Marquis du. Attachéau consulat } \\
\text { de France }\end{array}$ & $\begin{array}{l}\text { Baron Régis de Vitrolles (18??-19??). French Consul, Montreal } \\
(1923-1928)\end{array}$ \\
\hline
\end{tabular}




\section{Acknowledgements}

I owe thanks above all to Olivier Messac for frequently answering my questions with valuable information about his grandfather Régis Messac, and for sending me copies of Régis Messac's correspondence, photographs, articles, and republished books, several of which are cited here. I am also grateful to Marc Angenot, holder of the James McGill Chair of Social Discourse Theory, McGill University, for sharing comments on Messac and Smith Conundrum; at the McGill University Archives to Gordon Burr, Senior Archivist, for much assistance over the years, Bruce Dolphin, Mary Ellen W. Houde, David Poliak, Theresa Rowat, Director, for careful help with photographs, and Jean-Marc Trembley; staff and volunteers, especially Kelly Walsh, of Atwater Library and Computer Centre, Montreal; Anne Garrison, McCabe Library, Swarthmore College; Kathleen MacKenzie, Archivist, St. Francis Xavier University; Greg Prickman, Head, Special Collections \& University Archives, University of Iowa Libraries; Moira Rankin, archivist, University of Glasgow; Carl Spadoni, Director, William Ready Division of Archives and Research Collections, McMaster University; Joel Natanblut, Digitization Administrator and Amy Buckland, eScholarship, ePublishing \& Digitization Coordinator, McGill Libraries; Alice Messac, Carol Wiens and Nancy Walkling.

\section{ABREVIATIONS}

\section{MUA McGill University Archives}

MG Manuscript Group (private fonds)

RG Record Group (administrative fonds)

C Container

RG2 Records of the Principal (McGill)

RG7 Records of the Registrar (McGill)

RG32 Records of the Dean of Arts (McGill)

RG49 Records of the Information Office/Public Relations (McGill)

\section{ENDNOTES}

${ }^{1}$ A much briefer version of the topics covered here is my Postface to Smith Conundrum, Éditions ex nihilo, Paris 2010. The present article joins my others in Fontanus on McGill's portrayal in fiction and memoir: "Floreat Plutoria: Satirical Fiction about McGill," Fontanus, IX (1996); “The Gates of McGill: an Unpublished Novel of the 1920s by Dink Carroll," Fontanus, XI (2003); "Adversity Vanquished: Memoirs of a McGill Medical Student, Harold W. Trott, 1918-1924," Fontanus, XII; and "Fiction, Faction, Autobiography: Norman Levine at McGill University, 1946-1949," Fontanus, XII.

${ }^{2}$ Library and Archives Canada (LAC), Department of Immigration and Colonization, Border Entry Records. The records (Forms 30 and 30A) of the Messacs' arrival and their acceptance as landed immigrants on 3 October 1924 are on Microfilm Reels, T-15,127 and T-15,309. There are two copies of Form 30A, one all in Messac's handwriting, the other partly typed at the beginning but mainly in Messac's handwriting. Another form (paginated 18,721 - the rest of the forms did not have page numbers) titled "Particulars When Family Accompanying" was signed by Messac but typed, presumably by an official. It is stamped "Guided." Under remarks it is noted that Messac "is going to teach French at McGill University for three years, and if possible will likely make his permanent home in Montreal." Immigration records 1925-1935 are digitized and indicate that Régis, Germaine, Serge and Ralph re-entered Canada on 31 Oct. 1926 (arrived at Quebec on S.S. Alaunia (Cunard). On 21 Sept. 1928, Régis, Germaine, Serge and Ralph sailed from Le Havre, re-entering at Quebec on S.S. Albertic 29 Sept. 1928. They had left Montreal 30 May 1928. The references to the Messacs in 1926 \& 1928 are Immigration Records, 19251935, RG 76-Immigration series C-1a: microfilm reels T-14,729, 1926 volume 23, p.5, and T-14,749, 1928, volume 26, p.130. In 1928 Messac, perhaps with sly humour, gave his employer as Sir Arthur Currie, Principal of McGill University. Unlike the crossing of 1924, this passage ( $3^{\text {rd }}$ class) was paid by Messac. The 1928 record includes Messac's middle name: Gilbert.

${ }^{3}$ Email, Olivier Messac to Robert Michel, 22 mai 2011; 12,13,14 July 2012. Germaine inscribed a copy of Fleurs du mal to Régis in 1918 on her $27^{\text {th }}$ birthday to the effect: why marry when we please each other thus.

${ }^{4}$ Mainly by Éditions ex nihilo, Paris, under the general editorship of Messac's grandson Olivier Messac.

${ }^{5}$ Natacha Vas-Deyres and Olivier Messac, eds., Régis Messac: un écrivain journaliste à re-connaître, Éditions ex nihilo \& Université Michel-deMontagne-Bordeaux3, 2011.

${ }^{6}$ Messac was appointed at the (low) level of assistant for 1923-1924: Glasgow University Court minutes, 4 Oct. 1923 (C1/1/31, p. 14). This is the only reference found to Messac, for which I owe thanks to Moira Rankin, archivist, Univ. of Glasgow.

${ }^{7}$ Ralph Messac, "Le Detective Novel ': histoire d'une these," Quinzinzinzili: le bulletin messacquien, no. 3, été 2008, 16, and email 2011-2012 from Olivier Messac.

${ }^{8}$ McGill University Calendar 1924-1925, 121-122; Principal Sir Arthur Currie to Alexis Martin, Victoria, B.C., ca. 1924, Acting Principal C. F. Martin, General Correspondence, 1922-38, MUA, RG2, C47, file 483; W. Bovey to C.A. Magrath, 30 Nov. 1925, "McG 1922-1939," MUA, RG2, C47, file 478. Jewish enrolment was high but Jewish applicants would soon be subject to quotas or higher matriculation standards or both.

${ }^{9}$ Hermann Walter was Lecturer in Modern Languages, 1901-1902, Prof. of German, 1902-1936.

${ }^{10}$ Joseph L. Morin, (B.A. McGill 1880), Hon. D.D., 1942 was Lecturer in French 1893-1907, Assist. Prof., Modern Languages, 1893-1922.

${ }^{11}$ The internal McGill developments appear in the minutes of the Board of Governors, especially under the dates 3 Oct. 1921 (trouble between Walter and Morin, fear for McGill's reputation); 24 Oct. 1921 (suspension of Walter); 19 Dec. 1921 (reinstatement of Walter); 1 May 1922 (suspension of Walter, reinstatement of Morin but Morin to retire after next session); 10 Aug. 1922 (continued suspension of Walter); 27 Oct. 1922 (there will be a new court case, Walter suspension continued); 29 Jan. 1923 (Walter reinstated, Modern Languages to split into German and French, Walter to head German); 30 July 1923 (Morin resignation noted).

${ }^{12}$ There were no Italian or Spanish departments yet so in effect it was the French Department.

${ }^{13}$ The Principal occasionally assured parents that their children would not acquire Quebec French accents in McGill French courses, while Stephen Leacock attested in 1924, that in staffing the French Department, "we only take French people." Department of French-vacancies, ca1920-1930 (includes Leacock to "Wilfred" 26? June? 1924), MUA, RG 32, C 8, file 2253.

${ }^{14}$ Durand said the jury found in Messac: "la solidité et la précision de connaisance, une grande clarté d'exposition, et, dans la dissertation écrite sur un subject littéraire, un art de la composition et un réel talent de style qui lui ont valu le succès le plus mérité." Department of Modern Languages-French, 1922-1925, MUA, RG 2, C 61, file 1001.

${ }^{15}$ Department of Modern Languages-French, 1922-1925, MUA, RG 2, C 61, file 1001, general testimonials by René Durand (in French, 6 avril 1924), Prof. Fèlix Gaiffe (in French, 3 avril 1924), Charles A. Martin (1 June 1924).

${ }^{16}$ Algy Noad Fonds (mixed with Harold Files Fonds), MUA, MG1063, notes on Poe, n.d. 
${ }^{17}$ Course descriptions and instructors are given in the annual McGill University Calendar. French Dept. staff during Messac's time, 1924-1929, with overlaps, were: Professor and Chairman, René du Roure (1912-1914, 1922-1940); Associate Professor: Paul Villard (1915-1935); Assistant Professors: Régis Messac, Mrs. Lucie Touren Furness (1918-1953), Laurence A. Bisson (1926); Lecturers: Mlle. B. Framery 1924-25) Mme. Jeanne Durand-Joly (1928-1930), André Roche (1923-1926), L. d'Hauteserve (1926-1960, later years Professor), Mlle. Benoit (1926-7). This does not include part time or French Summer School staff. Female French instructors usually resided in Royal Victoria College if unmarried.

${ }^{18}$ Letters, du Roure to A.P. Glassco, Secretary, McGill University, 20 Sept.1926; du Roure to Dean MacKay, 13 Oct. 1926, French Department, 1920-1946, MUA, RG32, C19, file 126. Similar situation in Fall 1927: du Roure to MacKay, 4 Oct. 1927, MUA, RG32 C19 file 126.

${ }^{19}$ Report of Dean of McGill College (Ira MacKay), ca. 1929, Arts and Science, General, 1927-33, MUA, RG2, C58, file 902.

${ }^{20}$ Régis Messac, Le 'Detective Novel' et l'influence de la pensée scientifique, Paris 1929, republished with notes, Encrage, Paris 2011; Ralph Messac, "Le Detective Novel': histoire d'une these," Quinzinzinzili: le bulletin messacquien, no. 3, été 2008, 16.

${ }^{21}$ Le voyage de Néania, 1926, published anonymously, reviewed favorably in Le Progrès civique, no. 395, 5 mars 1927, 390. To be republished by Éditions ex nihilo, Paris.

${ }^{22}$ Régis Messac, "Bulwer-Lytton et Dostoievski-de Paul Clifford à Raskolnikov," Revue de literature comparée," no. 4, 1926, 638-653; "Déterminisme et histoire littéraire," la Science moderne, sept. 1926, 480483; "L'Homme artificial," la Science moderne, vol. iv, juin 1927, 281-284; "l'Homme invisible," la Science moderne, vol. v, 1928, 276-278; "Autour de Gavroche," Revue d'histoire littéraire de la France, xxxv, 1928, 577-589; "Le style du roman feuilleton," la Grande Revue (Paris), no. 12, déc. 1928, 221-234; "Fenimore Cooper et son influence en France," Publications of the Modern Language Association of America, vol.XLIII, no. 4, Dec. 1928,11991201; "Voyages modernes au centre de la terre," Revue de literature comparé, no. 9, jan. 1929, 74-104. Possibly written before arriving at McGill was "Cain et le probème du mal," Revue de literature comparé, vol. 4, oct.-déc. 1924, 620-652. His secondary thesis, Influences françaises dans l'auvre d'Edgar Poe, Librairie Picart, came out in 1929. These citations are from Robert Michel, Postface, Smith Conundrum, Éditions ex nihilo, Paris, 2011, 169 as well as additions received from Olivier Messac.

${ }^{23}$ E.A. Everts, Library, U.S.M.A., West Point, to Messac, 19 Aug. 1927; Harry Clemons, University of Virginia to Messac, 9 July 1928, 12 Oct. 1928 (in the latter, Clemons also congratulates Messac on having his thesis ready for the press). Photocopies kindly supplied of originals in possession of Olivier Messac, Fonds Régis Messac, Paris.

${ }^{24}$ Régis Messac to Thomas O. Mabbott, 30 Nov. 1928, Thomas O. Mabbott Papers, MsC 429, Special Collections \& University Archives, University of Iowa.

${ }^{25}$ P.D. James, Talking About Detective Fiction. Alfred A. Knopf, New York, Toronto 2009, 175.

${ }^{26}$ Astrid Llado, "Messac en Amérique" Régis Messac : un écrivain journaliste à re-connaitre, ed. Natacha Vas-Deyres and Olivier Messac, Éditions ex nihilo, Paris, 2011, Éditions ex nihilo, Paris, 2011, 101-114.

${ }^{27}$ Pierre-Gilles Pélissier, "Germes journalistiques de la fiction messacquienne," Régis Messac: un écrivain journaliste à re-connaitre, 115-128.

${ }^{28} \mathrm{His}$ articles in this Parisian journal were unlikely to have been read at McGill. In addition to academic articles on Determinisme and on Bulwer Lytton and Dostoyevski, he reported four of his articles in Le Progrès civique in the section of the McGill Annual Report for staff publications: they were on Anatole France, Herman Melville, "Une heure avec les fondementalistes," and "Homais à l'américaine," McGill University Annual Report, 1926-1927, 24. No publications by Messac were listed in Annual Reports for 1924-1925 and 1925-1926.The 1927-1928 and (abridged) 1928-1929 reports did not list staff publications.

${ }^{29}$ For example, letters criticizing Messac's "L'hygiène américaine," both signed "Un Français des Etats-Unis: Le Progrès civique, no. 392, 19 fév. 1927, 33; no. 400, 16 avril 1927, 32.
${ }^{30}$ Astrid Llado, "Messac en Amérique," Régis Messac: un écrivain journaliste à re-connaitre, 111.

${ }^{31}$ Régis Messac, "C'est entendu: les ouvriers américains ont leur auto... mais ils l'achètent à la petite semaine," Le Progrès civique, no. 325, 7 nov. 1925, 15-18.

${ }^{32}$ Régis Messac, "Les Chevaliers du Conformisme," Le Progrès civique, no. 330, 12 déc. 1925, 20-21. See Llado, "Messac en Amérique,"Régis Messac: un écrivain journaliste à re-connaître, 110.

${ }^{33}$ Régis Messac, "Le fruit defendu," Le Progrès civique, no. 343, 13 mars 1926, 20-21. Readers' reaction and Messac's reply were published in nos. 344, 31; 349, 31-33; 352, 30-31.

${ }^{34}$ Lettre, Messac, Montreal, 31 mars 1926, Le Progrès civique, no. 349, 24 avril 1926, 31-32.

${ }^{35} \mathrm{He}$ had read these regulations and perhaps also experienced them when landing in New York.

${ }^{36}$ Stephen Leacock, My Discovery of England, Dodd, Mead, New York 1922, 14.

${ }^{37}$ Régis Messac, "L'intelligence américaine et les problèmes de l'immigration," Le Progrès civique, no. 335, 16 janvier 1926, 86-87. The title conveys Messac's usual irony.

38"Mental Tests for Baylor Students", McGill Daily, 28 Oct. 1924, 1. Similarly, "Method Needed to Measure Intellect" appeared in the Daily, 14 Dec. 1928, 4.

${ }^{39}$ Régis Messac, "Jim Crow: le Noir et le Blanc," Le Progrès civique, no. 365, 14 août 1926, 17-19 ; Llado, "Messac en Amérique,"Régis Messac: un écrivain journaliste à re-connaître, 112.

${ }^{40}$ Régis Messac, "Une heure avec les fondamentalistes," Le Progrès civique, no. 381, 4 déc. 1926, 10-11.

${ }^{41}$ Régis Messac, "L'hygiène américaine, quand on la regarde d'un peu près," Le Progrès civique, no. 387, 15 jan. 1927, 8-10. Messac reponded to criticism from French people living in the U.S. in No. 405, 21 mai 1927, 36-37.

${ }^{42}$ Régis Messac, "Herman Melville," Le Progrès civique, no. 395, 12 mars 1927, 17-18; Le 'Detective Novel', (2011 edition), 465.

${ }^{43}$ Régis Messac, "Anatole France vu par les Américains," Le Progrès civique, no. 398, 2 avril 1927, 16-18.

${ }^{44}$ Régis Messac, "Les tabloids-Une formation nouvelle du journalisme aux Etats-Unis," Le Progrès civique, no. 415, 30 juillet 1927, 16-18.

${ }^{45}$ Régis Messac, "La femme isolée aux Etats-Unis," Le Progrès civique, no. 419, 27 août 1927, 18-20. Regarding frivolous topics, Messac may have been thinking of a talk at the McGill women's Société Française on the fashion of short hair for women, which concluded that women were conquering all "by short hair and short skirts," McGill Daily, 4 Nov. 1926, 1; 5 Nov. 1926, 1.

${ }^{46}$ Régis Messac, "La foi, la fausseté et la faillite de la 'Christian Science," Le Progrès civique, no. 434, 10 déc. 1927, 20-22, discussing W. Riley, F.W. Peabody and C. Humiston, The Faith, the Falsity and the Failure of Christian Science, 1925. Objection soon came from Caroline Getty, Christian Science Committee on Publication for France: no. 436, 37.

${ }^{47}$ Régis Messac, "Homais à l'américaine," Le Progrès civique, no. 361, 17 juillet 1926, 14-16.

${ }^{48}$ Régis Messac,"Les plumatifs et le veau d'or," Le Progrès civique, no. 454, 28 avril 1928, 18-19.

${ }^{49}$ Régis Messac, "Ne nous extasions pas sur le sport américaine! Connaisons-pour les éviter - ses tares profondes," Le Progrès civique, no. 469, 11 août 1928, 14-16.

${ }^{50}$ Régis Messac, “Une revolution, quest-ce que c'est?” Le Progrès civique, no. 467, 28 juillet 1928, 23-24.

${ }^{51}$ Régis Messac, "La guerre du Pacifique," Le Progrès civique, no. 487, 15 déc. 1928, 8-10. A reaction, that war between America and Japan was unlikely, was published in no. 492, 19 jan. 1929, 30.

${ }^{52}$ According to Lovell's Montreal Directory, the Messacs lived at Apartment 8, 2024 St-Denis, now a hotel (Lovell's 1925-26, 1154); 2045 Blvd StJoseph Est on $2^{\text {nd }}$ or $3^{\text {rd }}$ level (Lovell's 1927-28, $108 \& 1215$ ); and 6525 Ave. Molson (Lovell's 1928-29, 352 \& 1284). 
${ }^{53}$ Régis Messac, Réflexions sur les voyages," Les Primaires, avril 1932, $283-$ 287.

${ }^{54}$ The book was Neuvaine à saint Pierre Claver, Montreal 1923, 81 pages. Claver, patron saint of slaves, ministered to African slaves in New Spain (Grenada) and died of Parkinson's disease in 1684.

${ }^{55}$ Régis Messac, "Histoires Canadiennes," L'Idée Libre, 12 ème Série, no. 6, juin 1935, 242-245. They spoke in French of course. At this time, ca. 1925 to 1927 , the Messacs lived at 2045 Blvd. Saint-Joseph Est, a residential French-speaking neighbourhood close to downtown Montreal, opposite the church. This and several other articles by Messac in the 1930s were kindly selected and sent by Olivier Messac.

${ }^{56}$ Email, Olivier Messac to Robert Michel, 12 July 2012.

${ }^{57}$ Old McGill, 1924, 36.

${ }^{58}$ The Société Française narrowly lost to the Cercle, defending the resolution that man not woman constitutes the weaker sex: McGill Daily, 4 Nov. 1924, 3; 18 Nov. 1924, 1.

${ }^{59}$ The Daily seldom used French accents. Roche humorously complained about this in its coverage of the Cercle, McGill Daily, 30 Nov. 1925, 2. The Daily's spoof issue, The Mongrel Daily (April Fool's Day, 1925), 40, retorted with deliberate lack of accents: "There will be a meeting of the Societe Francais, the Societe Francaise and the Societe Francaise [sic] in the Music Room to-night. The speaker will not be present as he was forced to roche away for some inexplicable reason."

${ }^{60}$ McGill Daily, 16 Oct 1924, 3.

${ }^{61}$ In Montreal Standard, 5 Feb. 1921. Leacock bibliographies: Ralph Curry, "Stephen Leacock: the writer and his writings" (bibliography), Leacock: a Reappraisal, ed. David Staines, University of Ottawa Press, Ottawa, 1986, 143; Carl Spadoni, A Bibliography of Stephen Leacock, ECW Press, Toronto 1998.

${ }^{62}$ McGill Daily, 18 Oct. 1924, 1; 28 Oct. 1924, 1. The Daily gave fairly detailed summaries of Cercle debates. Group portraits of the student executives and staff advisors of the Cercle Français (of du Roure and Villard, not Messac or Roche) and Société Française are found in the Old McGills. So far as images go, Messac was an invisible man at McGill. He is found in no photographs in McGill's collections nor in the indexes to the Notman Photographic Collection at McCord Museum.

${ }^{63}$ For example, McGill Daily Literary Supplement, vol. I, no. 4, 29 Oct. 1924, 2 .

${ }^{64}$ McGill Daily, Railways: 22 Nov. 1924, 1; 24 Nov. 1924, 1,3; 25 Nov. 1924, 1,3; Pen vs. Sword: 1 Dec., 1924, 1; 6 Dec. 1924, 1, 3; 8 Dec. 1924, 1; 9 Dec. 1924, 1 (latter story in French, a rare occurance).

${ }^{65}$ McGill Fortnightly Review, vol. 1, no. 6, 6 Feb. 1926, 47-48.

${ }^{66}$ McGill Daily, 23 Feb. 1925, 4; 24 Feb. 1924, 1.

67 “Cercle held Initial Meeting Last Evening," McGill Daily, 20 Oct. 1925, 1.

68"Second Séance of the Cercle Francais Held," McGill Daily, 1,2. Does not specify who told which anecdote.

${ }^{69}$ McGill Daily, 23 Nov. 1925, 1.

${ }^{70}$ McGill Daily, 24 Nov. 1925, 1.

${ }^{71}$ McGill Daily, 25 Nov. 1925, 2; 26 Nov. 1925, 2.

${ }^{72}$ McGill Daily, 18 Nov. 1926, 1.

${ }^{73} \mathrm{McC}$ ullagh attended some meetings of the Cercle, for example, the meeting of 22 Jan. 1929: McGill Daily, 23 Jan. 1929, 1. Perhaps he and Messac were well acquainted. A less likely candidate from Classics is Carleton Stanley.

${ }^{74}$ Editorial, unsigned, McGill Fortnightly Review, vol. 2, no. 7, 10 Mar. 1927, 1. The Fortnightly mocked McGill's subservience to businessmen and criticized many aspects of university life.

${ }^{75}$ Letter to the Editor by Abby Litovsky (B.A. 1926), McGill Daily, 20 Nov. 1926,4 , decries "the entrance into our college life of a highly developed form of professional sport... it will soon come to this that prize-fighters and weight-lifters will soon have more say in our college life than principals and professors."

${ }^{76}$ McGill Daily, 24 Feb. 1928, 1.
${ }^{77}$ Robert Michel, "The Gates of McGill: an unpublished novel of the 1920s by 'Dink' Carroll," Fontanus, XI, 2003, 12-60; Michel, "Fiction, Faction, Autobiography: Norman Levine at McGill University, 1946-1949," Fontanus, XII, 2010, 63-104. The genre was already long established in England with Edward Bradley's Verdant Green (1857), Thomas Hughes's Tom Brown at Oxford (1861) and Max Beerbohm's fantasy Zuleika Dobson (1911).

${ }^{78}$ The chapters were unnumbered; most were first published serially in Le Progrès civique, beginning in no. 475, 22 Sept. 1928 to no. 625, 20 Sept. 1931 in the following order: La fille de Peudzippah, no. 475, 22 sept. 1928; Film interdit par la Censure, no. 522, 17 août 1929; Jamais content, no. 534, 9 nov. 1929; Le Rah-Rah-Boy, no. 570, 19 juillet 1930; Honoris Causa, no. 575, 23 août 1930; La bataille de Tipperary, first part, no. 578, 13 sept. 1930 and second part, no. 579, 20 sept. 1930; L'Academicien I, no. 620, 4 juillet 1931; L'Académicien II, no. 621, 11 juillet 1931; L'Académicien III, no. 622, 18 juillet 1931; L'Académicien IV, no. 623, 25 juillet 1931; L’Académicien V, first part, no. 624, 1 août 1931 and second part, no. 625, 8 août 1931. Le Professor Talkinghorse et l'idée de genie was published under the pseudonym Laurent Zurbarran in le Quotidien, no. 4062, 31 mars 1934. There is no known pre-publication of the chapters Graeculus esuriens, Les livres and On rentre. Regarding the title, O. Messac suggests that Régis chose "Smith" as the most common Anglo-Saxon surname and "Conundrum" as suggestive that founder Smith's social ascent was an enigma.

${ }^{79}$ Régis Messac, Smith Conundrum: roman d'une université américaine. The novel was announced in the list of la Fenêtre ouverte in 1935 but did not appear. Finally it was published as a complete book (with chapters in slightly different order than that in which the serial versions appeared) by L'Amitié par le Livre, Querqueville (Manche), vi \& 169 pp., 28 francs) in 1942. The dates of writing Messac gave in the 1942 edition, of octobre 1930-février 1931, are too condensed. The 1942 edition is very rare as most copies were forbidden and possibly destroyed by the German occupiers, others accidently destroyed by the advancing Americans. Smith Conundrum was republished by Éditions ex nihilo, Paris, 190 pp., 2010 with a preface by Marc Angenot and an afterword by Robert Michel (afterword translated from English into French by Jean-Marie Jot). The 1942 edition published L'Académicien as one chapter with 5 parts. The 2010 edition published L'Académicien as 5 separated chapters and Graeculus esuriens as two separated chapters modifying its 1942 division into 2 parts in one chapter. The 1942 and 2010 texts appear to be identical and the 2010 edition has 7 explanatory footnotes. With a colorful new cover by Quebec illustrator Cozic, the book is available from Éditions ex nihilo, 42 bis rue Poliveau, Paris V.

${ }^{80}$ Marc Angenot's note about his discovery of Smith Conundrum appeared in the McGill Reporter, 23 April 1975, with a translation of the chapter Honoris Causa by Gladys Quirk. At that time, I photocopied Angenot's photocopy (from BnF) of the 1942 edition for the McGill University Archives where I was an archivist. See also Angenot, "Smith Conundrum: un roman satirique sur McGill University," Voix et images, vol. 3, no. 1, 1977, 162-165 and Angenot, Préface, Smith Conundrum (Éditions ex nihilo, Paris, 2010). A small file on the discovery was assembled by the McGill Information Office, 1975, MUA, RG49, C101.

${ }^{81}$ Marc Angenot, preface to Smith Conundrum, 2010 edition, 12-13.

${ }^{82}$ L'Académicien, [V part 2], Le Progrès civique, no. 625, 8 août 1931, 14.

${ }^{83}$ Three weeks after its ratification, the Kellogg Pact was mentioned in the first published chapter: "La fille de Peuzippah," Le Progrès civique, no. 475, 22 September 1928.

${ }^{84}$ Except for the chapter Honoris Causa translated by Gladys Quirk, Mc Gill Reporter, 23 April 1975.

${ }^{85}$ As well, Pluche's name suggests peluche, the plush of teddy bears. A student in the novel refers to Pluche having a bearish reputation. Most likely, as Olivier Messac suggests, Pluche derives from Abbé Pluche (1688-1761). “André J." probably comes from Messac's colleague André J. Roche; and indeed, "Pluche" shares the sound of "Roche." Most fancifully, an André M.H. Pluche (1887-1915), sergent-fourrier au 67 ème RI was killed, MPLF, 21/6/1915; could Messac have given him a new life? Pluche calls himself "l'ex-quartier maitre" in Jamais content.

${ }^{86}$ Canadian immigration officers described Messac as five feet six inches tall $(=167.6 \mathrm{~cm})$, with brown eyes and brown hair. 
${ }^{87}$ Sinclair Lewis, Babbitt, 1922, chapter III, pt. iii; chapter V, pt. ii. Messac also used the term "California Building" in his tirade against the "Bunk" of American civilization: “Bunk; ou Plein la vue!” Le Progrès civique, no. 352, 15 mai 1926, 16 .

88"Roddick Gates nearing completion," McGill Daily, 9 Dec 1924, 2; "Roddick Gates are now closed to traffic. Cost \$50,000." McGill Daily, 5 Jan. 1925, 1. Messac, like his students, probably read the Daily.

${ }^{89}$ Ira MacKay, Dean of Arts to Principal Currie, 21 April 1926; Currie to MacKay, 22 April 1926, Arts and Science-General, 1919-1926, MUA, RG2, C58, file 903.

${ }^{90} \mathrm{My}$ count from the McGill Calendar, 1927-1928. There were other appointments, mainly demonstrators in medicine and science, totalling another 197.

${ }^{91}$ Messac, Le 'Detective Novel', (2011 edition, 540 n.1).

${ }^{92}$ For example, no letter or reference to Messac appears in The Letters of Stephen Leacock, ed. David Staines with Barbara Nimmo, Oxford University Press, Don Mills, Ontario, 2006 (564 pp.) or in other writings on Leacock.

93 "Bunk" was in vogue; just after Messac's "Bunk," Leacock titled an article "Old Junk and new Bunk," Collier's 78, 30 Oct. 1926, 20: Ralph R. Curry, "Stephen Leacock: the Writer and his Writings," Leacock: a Reappraisal, ed. Staines, 20 .

${ }^{94}$ Stephen Leacock, "Rah! Rah! College," Afternoons in Utopia, Macmillan of Canada, Toronto, 1932, 120,125.

${ }^{95}$ Leacock, My Discovery of England, 115. The chapter "Oxford as I See It" contains perhaps Leacock's fullest, brightest critique of North American universities. While not against women's education (102-109), Leacock argued against coeducation, claiming that women did better in women's colleges: "They are freer, less restrained. They discuss things openly in their classes; they lift up their voices, and they speak, whereas a girl in such a place as McGill, with men all about her, sits for four years as silent as a frog full of shot": 106. Perhaps Pluche's talkative Goldeye Belemnith was reacting against this timid stereotype! Leacock thought most women would marry, making their university learning superfluous and soon forgotten. In My Discovery, 14, Leacock also tells British officials he is an "anarchistic polygamist."

${ }^{96}$ See Ian Ross Robertson, "The Historical Leacock," Leacock: a Reappraisal, ed. Staines, 47-48.

${ }^{97}$ The headings here are the Smith Conundrum chapter titles. As the texts of 1942 and 2010 are the same and the chapters are short, page citations are not given.

${ }^{98}$ Waugh was Kingsford Chair of History, 1925-31, author of James Wolfe, man and soldier, Montreal, L. Carrier, 1928.

${ }^{99}$ Report by Principal A.W. Currie, McGill University Annual Report 1924-1925, 35-38.

${ }^{100}$ French Department, 1920-1946, MUA, RG2, C47, file 483.

${ }^{101}$ According to J. Harkness, Acting Dean of Arts, 1921 in c.v. of Villard, probably compiled for the Dean: French department, 1920-1946, MUA, RG32, C19, file 126.

${ }^{102}$ In 1927-1928 McGill had 8 students from China and 3 from Japan according to Old McGill, 1929, 21.

${ }^{103}$ Messac continued inventing funny names, such as Tenterhook, Compost and Foothold, in another novel focusing on his American targets: religion, the Ku Klux Klan and maltreatment of Blacks: Le miroir flexible, 1933, republished by Éditions ex nihilo, Paris, 2008.

${ }^{104}$ Thomas O. Mabbott Papers, MxC 429, Special Collections \& University Archives, University of Iowa; C.K. Ogden Fonds, William Ready Division of Archives and Research Collections, McMaster University; and David H. Keller Collection, McCabe Library, Swarthmore College.

${ }^{105}$ DuBoyce as the inspiration for "des Boys" was suggested by Olivier Messac.

${ }^{106}$ Listed as René des Roys du Roure in Lovell's Montreal Directory, 1926-27 (Apt. A, 70 Cedar Ave.).

${ }^{107}$ On Chicago influences at McGill in sociology and social work, see Marlene Shore, The Science of Social Redemption: McGill, the Chicago School, and the Origins of Social Research in Canada, University of Toronto Press, Toronto, 1987, and on Caldwell, 32-36, 51.

${ }^{108}$ A description of Columbia's French and other summer sessions is given by Paul Hazard, "Six professeurs Français à l'Université Columbia," Revue des Deux Mondes, oct. 1923, 622-634.

${ }^{109}$ Juvenal, Satires, iii.76. Translations vary: "Command the little Greek to ascend to heaven and he will try to do it." I am indebted to Olivier Messac's remarks regarding Messac's meaning.

${ }^{110}$ Régis Messac, A Bas le Latin! 1933, republished, ed. Olivier Messac with preface by Anne-Marie Ozanam, Éditions ex nihilo, Paris, 2010.

${ }^{111}$ Except with beginners, all French departmental teaching was supposedly done in French. Smith Conundrum indicates lapses into English occurred; in Jamais content, for example, des Boys says that we demand the students speak French, at least in the higher level classes.

${ }^{112}$ Leon Edel, “The Young Warrier in the Twenties," On F.R. Scott, ed. Sandra Djwa and R. St J. Macdonald, McGill-Queen's, Kingston and Montreal 1983, 10-11. Messac may have been well aware of literary efforts at McGill. Felix Walter, B.A. 1923, M.A. 1924, the son of Messac's friend Hermann Walter, wrote for the McGill Daily, ca. 1923-1924 and earned his doctorate in comparative literature under Messac's director F. Baldensperger from the Sorbonne in 1927. Leon Edel called Felix the "founding grandfather" of McGill's literary movement: ibid., 9. Perhaps Messac knew Felix.

${ }^{113}$ See Brian Trehearne, Aestheticism and the Canadian Modernists: Aspects of a Poetic Influence, McGill-Queen's, Kingston, Montreal, London 1989, 230-235. Messac may have enjoyed F.R. Scott's spoof of Pittsburgh's skyscraper university, with futuristic automation and a different degree offered on each of its 52 floors: Scott, "The Cathedral of Learning," McGill Daily Literary Supplement, 19 Nov. 1924, 1,4. See Comment elsewhere in this volume: Robert Michel, "Frank Scott's University of Dystopia, 1924."

${ }^{114}$ A shelf read of theses, 1925-1930, in McGill's McLennan Library, turned up the following M.A. theses presumably written for the French Department-supervisors were not specified: Alice Sharples, "Le théâtre en liberté de Victor Hugo," 1925; Edith Creighton, "La legend Napoléonienne dans l'oeuvre de Béranger," 1926; and Drucilla Stager, "Jeanne d'Arc dans le theatre modern anglais et français," 1926.

${ }^{115}$ The fullest account is Don Bell, The Man Who Killed Houdini, Véhicule Press, Montreal 2004, 68 and passim.

${ }^{116}$ Messac's use of "Syd" may come not only from "Cid" but from Syd Chaplin (Charlie's half-brother), who played in The Man on the Box (Warner Brothers, 1925), reviewed unfavorably in the McGill Daily, 26 Nov. 1925, 2. Another Messacquian extrapolation might have been C. Chaplin's film "The Kid" [Cid?] 1921!

${ }^{117}$ Régis Messac, "Bunk; ou Plein la vue! Le Progrès civique, no. 352, 15 mai 1926, 18. From minus habens - intellectually deficient.

${ }^{118}$ McGill Daily, 24 Nov. 1928, 1, 4. M. Joub, who played Rodrigue, complimented the McGill audience on its quick understanding compared to other Montreal audiences. This was stated to be the first performance of El Cid in Montreal. In November 1926, a recitation from El Cid had been given in Montreal: McGill Daily, 5 Nov. 1926, 1.

${ }^{119}$ Ralph L. Curry, Stephen Leacock: Humanist and Humorist, Doubleday \& Co., New York, 1959, 187.

${ }^{120}$ Brigitte Olivier-Cyssau, René du Roure, privately printed, ca. 2008 covers $\mathrm{du}$ Roure's family life as well as his career. Du Roure was preceded in the French Department (1895-1900) by another dramatic Frenchman, Maxime Ingres.

${ }^{121}$ The $3^{\text {rd }}$ floor of McGill's Arts Building still has small offices including one numbered 345 .

${ }^{122}$ Principal A.W. Currie to Consul General of France, Montreal, 6 Mar. 1922, Dept. of Modern Languages-French, 1922-1925, MUA, RG2, C61, file 1001. Du Roure asserted French was better taught in the primary schools of Montreal than in the rest of North America: R. du Roure to Members, Protestant Board of School Commissioners, ca. 1931-1932, MUA, RG32, C53, file 2000; R. du Roure to Vice-Principal Charles Martin, 21 Mar. 1929, "Dept. of Romance Languages, French, 1922-1933," MUA, RG2, C61, file 995. 
${ }^{123}$ René du Roure, "L’Appel de la Race," La Revue Moderne, vol. iv, no. 2, déc. 1922, 8-9. While the novel was signed "Alonié de Lestres", Du Roure emphasized that it was no secret that the author was "un historien canadien d'une certaine reputation." Du Roure published other articles in the same journal, including "La literature et les Loisirs," Ge année, no. 9, juillet 1925, 6-7.

${ }^{124} \mathrm{R}$. du Roure wrote to Dean of Arts Ira MacKay, 17 June 1926 requesting him and Principal Currie to approve Messac's returning late in Fall 1926 from researching in France; du Roure would teach his courses: "French Department 1920-1946," MUA, RG32, C19, file 126. Du Roure had to cover for over a month as immigration records show that the Messac family returned to Quebec on the the S.S. Alaunia (Cunard) on 31 October 1926: LAC, Immigration Records, 1925-1935, 1926,vol 23, p.5, microfilm reel $\mathrm{T}-14729$.

${ }^{125}$ Courtesy of Marc Angenot, the present owner.

${ }^{126}$ Clifton L. Hall (M.A., McGill 1932), "Men Who Taught Me," Peabody Journal of Education, vol. 46, no. 3, Nov 1968, 131-135; cited by Brigitte Olivier-Cyssau, René du Roure, 2008, unpaginated.

127 “Professor René du Roure dies suddenly," McGill News, Winter 1940, vol. 22, no. 2,54 .

${ }^{128}$ The works not cited in my text are Jacob Bohm, L'aurore naissante ou la racine de la philosophie (an edition was published in Milan, 1927); Stéfan Christesco, l'Éthéronique et les archives de l'univers, Paris 1928; Wolfgang Kéohler, l'Intelligence des singes supérieurs, Paris 1927; Ch. Picard, "Phèdre à la balançoire et le symbolisme des pendaisons," Revue Archéologique, $5^{\text {th }}$ ser. 28 (1928), 47-64. An internet search failed to verify one title: Bernadotte Wilhalmhjur, "Les orages dans la littérature finnoise." McGill's Library holds Hoxie Fairchild, The noble savage: a study in romantic naturalism, Columbia University Press, New York 1928, Accession no. 241209, date 1929- perhaps Messac like Pluche requested it.

${ }^{129}$ In the preface to Le 'Detective Novel,' Messac thanked "le Dr Lomer et tout le personnel de la 'Redpath Library' qui m’ont considérablement aidé à réunir ma documentation....”

${ }^{130}$ Fernand Baldensperger, Études d'histoire littéraire (1907), borrowed in April 1928, before Messac would have seen him that summer. The McGill French professors may have recommended books to each other: A.J. Roche and Messac borrowed Pierre MacOrlan, La cavalière Elsa (1922) on 15 May 1926 and 7 July 1926 respectively, the next borrower was Touren Furness in Feb. 1928.

${ }^{131}$ Borrowed between 5 May 1926 and 9 Oct. 1928, these 17 cards and books bear accession numbers between 213,425 and 235,681, which correlate with the run of numbers assigned to new books at that time.

${ }^{132}$ Assistant Bursar, McGill, to Messac, 5 Dec. 1927. Supplied by Olivier Messac from the Fonds Régis Messac, Paris.

${ }^{133}$ Régis Messac to Thomas O. Mabbott, 30 Nov. 1928, Thomas O. Mabbott Papers, MsC 429, Special Collections \& University Archives, University of Iowa.

${ }^{134}$ Régis Messac, Le 'Detective Novel' et l'influence de la pensée scientifique, Paris 1929, McGill Libraries, Rare Book Division, PN3448 D4 M47 1929. Lomer gave the Library his copy.

${ }^{135}$ Old McGill, 1927, 151.

${ }^{136}$ Slightly simplified from Le Rah-Rab-Boy in Smith Conundrum. Messac has the students yell "C-O-N-N and "conn" perhaps adding a second "n" to avoid writing the derogatory French slang "con" for which a polite translation is "idiot." "Conundrum" and "conn" also suggest "connerie."

${ }^{137}$ The yell appears in the The McGill Song Book, published by the McGill Students' Council (1921) and other student publications, e.g., McGill Student Handbook, 1926-1927, 17; McGill Daily, 1 Oct. 1925, 4; 2 Oct. $1925,3$.

${ }^{138}$ The host Canadian Prime Minister Mackenzie King was not snubbed; he already had received an honorary degree from McGill in 1929.

${ }^{139}$ Woodhead, his humour, pipe smoking, and humorous verses about fellow staff are described by T.H. Matthews, "Woodie," McGill News, vol. 36, no. 3, Summer 1955, 18-19 and T.W.L. MacDermot, "William Woodhead: an Appreciation," McGill News, vol. 38, no. 4, Autumn 1957, $21,34$.
140"Imposing scenes at Conferring of McGill Degrees," Montreal Daily Star, 9 Apr. 1926. Honnorat towers over du Roure in the photograph, same source, 10 Apr. 1926. This and other news clippings on the Convocation are in MUA, RG7, McGill University Scrapbooks, vol. 6, 121-130. The speeches, list of those invited, and program of events are in the Minute Book of Convocation, 1909-1927, 518-521, MUA, RG7, C413, file 375. Coverage is also in McGill Daily, 21 Apr. 1926, 1. Related correspondence with Atholl, Honnorat, Baron de Vitrolles, et al.: "Honorary Degrees, 1924-1928," MUA, RG7, C52, file 961. An honorary degree was planned about the same time for Sir Alexander F. Whyte, who eventually was scheduled to receive his at the regular Convocation on 29 May 1926.

${ }^{141}$ In 1926 Ruttan was in conflict with the Dean of Arts over aspects of the Chemistry program: Dean Ira MacKay to Principal Currie, 15 Oct. 1926, MUA, RG2, C58, file 903. Old McGill 1929 was dedicated to Ruttan, retiring after 40 years (with colour photograph, 4-5).

${ }^{142}$ W.D. Woodhead, “The Professors, God Bless 'Em," McGill News, vol. 31, no. 4, Summer 1950, 18.

${ }^{143}$ Minute Book of Convocation, 1909-1927, 520, MUA, RG7, C413, file 375 .

${ }^{144}$ Gladys Quirk, "Honoris Causa, from the twenties, a Convocation lampoon," McGill Reporter, 23 April 1975, 5.

${ }^{145}$ Reported in the Montreal Gazette, and Montreal Daily Star, 3 May 1926.

${ }^{146}$ Paul Fussell updated this charge in Class, Ballantyne Books, New York, 1984, chapter 6 .

${ }^{147}$ S. Leacock, "A Convenient Calendar for Future Years," Old McGill 1931, 62. Decrying legislative or benefactors' attempts to control what was taught at universities, Leacock suggested that benefactors should merely say: "Here is a million dollars," and universities reply "Yes- here is an LL.D." From "Leacock Describes Colleges of Past and Present," Montreal Gazette, 24 Feb. 1926.

${ }^{148}$ Régis Messac, "Bunk; ou Plein la vue!” Le Progrès civique, no. 352, 15 mai 1926, 15-18.

${ }^{149}$ Information on the McGill French Summer School comes from the published calendars French Summer School, McGill University for the years 1925, 1926 and 1927 (the years Messac taught). The calendars gave courses with instructors' names and information on registration, examinations and activities. Copies are in files on the French Summer School in MUA, RG7, C39, file 269; MUA, RG7, C382; MUA, RG32, C10, file 127. Correspondence is in Dept. of Romance Languages-French Summer School, 1923-1926, MUA, RG2, C61, file 996; French Summer School, MUA, RG32, C10, file 127. Some School events were noted in the University Scrapbook of newsclippings, vol. 6, covering the mid and late 1920s, and in the McGill News.

${ }^{150}$ L'Académicien [I], Le Progrès civique, no. 620, 4 juillet 1931, 15.

${ }^{151}$ Messac and McGill were "Chicago-aware." Besides Leacock, Gordon Laing, former Dean of Arts 1921-1923 and head of Classics had come from University of Chicago and W.D. Woodhead, chair of Classics, had a Ph.D. from Chicago (McCullagh would obtain his Ph.D. there but later). Since its founding in 1890, Chicago had emphasized graduate research and was a powerhouse of social science research, influencing McGill initiatives (involving Leacock among others) in sociology and social work in the 1920s and 1930s: see Marlene Shore, The Science of Social Redemption.

${ }^{152}$ Marie Le Franc published a story with a French department head resembling du Roure and glimpses of what may have been the French Summer School's extra activities: women from Omaha and Charlottetown visiting the art museum and debates on such subjects as whether it is possible for married men to continue to love their wives: Visages de Montréal, Montreal 1934, 120-125.

${ }^{153}$ McGill University, French Summer School, Annual Report 1926. Reports on the School also appear in the regular published McGill Annual Reports and the minutes of the Board of Governors.

${ }^{154}$ William Weintraub, City Unique, Toronto 1996, 116-117, 119-120, 246-247. It was famous for performances by Lily St. Cyr in the 1940s.

${ }^{155}$ Alice Sharples Baldwin, "Du Roure's soul was French, his blood blue," The McGill You Knew, ed. E.A. Collard, Longman Canada, Don Mills, Ont., $1975,75-77$. 
${ }^{156}$ The press noted this production and a ballet solo dance by Miss L. McNea: "Students in Plays at the French School," Montreal Herald, 29 July 1927, MUA, RG7, Scrapbook of newsclippings, vol. 6, 275.

${ }^{157}$ Brigitte Olivier-Cyssau, René du Roure, 2008, unpaginated.

${ }^{158}$ Lucie Touren Furness, Je me souviens, multilith memoir, 1973, MUA, MG4015 (Acc. 83-044); in 1927 Du Roure and the Dean of Arts supported Touren Furness's continued teaching and a small increase of salary to bring hers up to that of male staff : R. du Roure to Dean Ira MacKay, 1 Oct. 1927, "French Department, 1920-1946," MUA, RG32, C19, file 126; du Roure to Principal Currie, 1 Oct. 1927, Dean Ira MacKay to Principal Currie, 8 Oct. 1927, both in "Department of Romance Languages - French, 1922-1933," MUA, RG2, C61, file 995. She remained on staff full time, according to the Calendars.

${ }^{159}$ Relevant correspondence is in Department of Modern Languages-French, 1921-1925, MUA, RG2, C61, file 1000; Principal Currie to L.A. Bisson, 23 Mar. 1926, Currie to Col. Alexander Macphail, 3 Apr. 1926, Department of Romance Languages-French, 1922-1933, MUA, RG2, C61, file 995; Principal Currie to Dean of Arts MacKay, 22 Apr. 1926, Arts and Science-General, 1916-1926, MUA, RG2, C58, file 903.

160"Prefers to Teach McGill Students", McGill Daily, 13 Oct. 1926, 1.

${ }^{161}$ L.A. Bisson, Arcachon, Gironde, France, to Principal Currie, 17 July 1926, annotated by Currie granting the request to report late; and A.P. Glassco to du Roure, 17 Sept. 1926, R. du Roure, 1922-1936, MUA, RG32, C53, file 1998. The date and location Bisson wrote from are further evidence he did not teach at the 1926 French Summer School session.

${ }^{162}$ R. du Roure to Dean Ira MacKay, 17 Nov. 1926, French Department,1920-1946, MUA, RG32, C19, file 126.

${ }^{163}$ Minute book, Board of Governors, Finance Committee, 1919-1931, 17 Feb. 1927, 542, MUA, RG4, C20, file 9026. Bisson had been appointed 6 May 1926, same source, 514. The Calendar for 1926-1927 did not indicate which courses Bisson taught; he may have been hired too late for inclusion. While no professor's name was assigned to the medieval literature course (p. 188), presumably Bisson taught it.

${ }^{164}$ Bisson wrote several books in the 1940 s, including A short history of French literature from the middle ages to the present day (Penguin, 1943, 1945). Earlier he published a thesis for Université de Bordeaux in 1932 on Le romantisme littéraire au Canada français, a topic he appears to have begun at the Sorbonne. D'Hauteserve would teach at McGill from 1926 to 1960.

${ }^{165}$ Correspondence on Sonet (who was not on staff) including du Roure's letter, 28 June 1928, is in "Department of Romance Languages, 1927-1933," MUA, RG2, C61, file 993.

166"Balderdash," meaning "nonsense," was a popular expression. For example, the Old McGill 1928, 38, biography of Guy F. Simpson, B.A. 1928, noted his favorite expression was "sentimental balderdash." Simpson was a member of the Cercle Français; Messac may have heard it first from him! Since "balderdash" in French means "connerie," Olivier Messac suggests a double analogy-between "connerie" and "Currie" and also between "connerie" and "la grande Cônerie," the name for "l'Université" in Messac's La Cité des asphyxiés (1937).

${ }^{167}$ Tommy Matthews (B.A., M.A. Oxford), longtime Registrar, began at McGill teaching math. The real McGill Arts Building also had a common room.

${ }^{168}$ In the preface to Le 'Detective Novel,' Messac thanked Walter "qui a gracieusement mis à ma disposition sa bibliothèque privée...."

${ }^{169}$ Messac noted of Walter's biography of the Jewish poet: "j'ai eu plaisir à voir comment vous aviez su vous dégager complètement du préjugé racial." The letter, Messac to Walter, 2 Feb. 1931, is in a scrapbook in the Hermann Walter Fonds, MUA, MG2014.

${ }^{170}$ Stephen Leacock, Arcadian Adventures Among the Idle Rich, John Lane, New York, 1914, 81.

${ }^{171}$ Winegar also wrote Problem in Bacteriology Clothing Study, Kansas State University, 1927, 28pp. Her research was reported on in The Literary Digest, 6 Oct. 1928, 23, in which she is affiliated to University of Nebraska. Winegar was a recognized expert on textiles and sanitation and gave public lectures. Euthenics is defined as "the science of improving human beings through control of environmental factors:" Funk $\mathcal{E}$ Wagnalls Standard Dictionary, New American Library, pb, no date.

${ }^{172}$ The students were always quoting Leacock's bon mots; however, Cadwallader Talkinghorse's research does not resemble Leacock's and Messac appears aimiably disposed to Leacock. Prof. William Caldwell, who may have lent his name and fame to Cadwallader T. was a "character," often mentioned in the Daily and Montreal press, receiving the Order of the White Lion Czechoslavakia (Montreal Gazette, 31 Jan. 1927), Order of Polonia Restituta (Montreal Daily Star, 21 Nov. 1927) and the like. He was made "officier d'Académie" for bringing understanding of French culture to the English speaking world: Montreal Gazette, 8 May 1929.

${ }^{173}$ Messac may be anticipating the start of the American Great Depression in late 1929 just after he left.

${ }^{174} \mathrm{Du}$ Roure forcefully requested - successfully - that Currie recommend to the Governors' Finance Committee modest salary increases to Professors D'Hauteserve, Furness, and Villard. He had asked for these (presumably including Messac) the previous year through regular channels without success: du Roure to Principal Currie, 10 Oct. 1929; Currie to du Roure, 10 Oct. 1929, Department of Romance Languages - French, 1922-1933, MUA, RG2, C61, file 995.

${ }^{175}$ Presumably Pluche meant he would leave at the end of the academic year the following June. No letter of resignation from Messac survives.

${ }^{176}$ Letter, Michel Poirier to Messac, 14 May 1928, Fonds Régis Messac, Paris; copy supplied by Olivier Messac. Glasgow University Calendar, 1923-1924, 26, lists Poirier as a temporary Assistant in French. He may have been there at the same time as Messac or earlier. Messac's name does not appear in the Calendar. My copy of Le 'Dectective Novel' (1929) is inscribed: "A mon excellent ami Michel Poirier cordial homage Régis Messac" (purchased from Kitazawa Bookstore, Tokyo, Dec. 2003).

177"The Acting-Principal submitted to the meeting the resignation of Professor Regis Messac to take effect at the end of this session. The meeting referred this to the Board of Governors with a recommendation that it be accepted:" Minute Book of the McGill Board of Governors Finance Committee, 1919-1931, 24 Jan. 1929, 606, MUA, RG 4, C 20, file 9026. The date of Messac's resignation is noted in courier des lecteurs, lettre de Robert Michel, Quinzinzinzili, no. 15, automne 2011. Ralph Messac had assumed the child's death was the immediate cause of the Messacs'return to France: "Le Detective Novel ': histoire d'une these," [reprinted in] Quinzinzinzili: le bulletin messacquien, no. 3, été 2008, 16. According to Ralph Messac, baby Francis had been dropped by his nurse and his broken leg was discovered too late; he did not survive an operation: "Régis Messac, écrivain, 2 août 1893-19...?" 813: les amis de la literature policière, no. 55, mai 1996, 61-63. Ralph M. also cites Marc Angenot on Messac's heavy use of McGill Library books.

${ }^{178}$ On Messac's arrest for non-violent assistance to the Resistance and his experience after arrest, see Régis Messac, Lettres de prison, Éditions ex nihilo, Paris, 2005. Interest in his life and work has been ever-increasing: see J.-J. Bridenne, "Hommage à Régis Messac," Fiction (Paris), No. 48, novembre 1957, 133-135; Pierre Versins, Encyclopédie de l'utopie des voyages extraordinaires et de la science fiction, Éditions L'Age de l'Homme S.A., Lausanne, 1972, 585-586; Eric Dussert, "Régis Messac, réformateur contrarié," Le Matricule des Anges, No. 25, janvier-février 1999, 57; Marc Angenot, Préface, Smith Conundrum, Éditions ex nihilo, Paris, 2010; C. Amoz, preface, Messac, Le 'Detective Novel,' Encrage, Paris, 2011; and Natacha Vas-Deyres and Olivier Messac, eds., Régis Messac: un écrivain journaliste à re-connaître, Éditions ex nihilo, Université Michel-deMontagne-Bordeaux3, 2011; as well as frequent articles in Quinzinzinzili, from 2007 on.

${ }^{179}$ Report of Dean of McGill College (Ira MacKay), ca. 1929, Arts and Science, General, 1927-33, MUA, RG2, C58, file 902. From 1929 to ca. 1931, McGill carried out surveys to improve standards, introduce stronger graduate programs, and prepare a fund campaign; the campaign did not take place owing to the Depression. The preliminary draft report of ca. June 1929 (Messac had just left McGill) on the French Department noted that McGill "is strategically situated to develop one of the finest departments of French on this continent.... The staff is quite inadequate to fulfill any such ambition; and here again an outstanding leader of reputation, with an intimate knowledge of French language, literature and history, would add 
materially to the strength of the Department, and with him there should be associated sufficient help to place this Department on a stronger footing and capable of widening the scope of the work necessary to be done both in instruction and in research." The draft perhaps gave insufficient credit to du Roure's teaching flair and successful running of the French Summer School and ignored the shortage of funding which made it difficult to hire eminent staff. See also the Martin-Colby Survey, MUA, RG2, C57, File 830, ca. 1929; also MUA, RG2, C36, file 121 and (Acc 27/1) "Faculty of Arts and Science, Report of the Special Survey Committee, 1930-31," typescript, $165 \mathrm{pp}$. There is further Survey material, ca. 1930-1931 in MUA, RG2, C58, files 875,876 . The files contain much statistical information and commentary on all McGill departments. 